Final Report

\title{
Design of Durable Concrete Railroad Crossings
}

FHWA/IN/JTRP-2002/28

by

\author{
Anthony J. Lamanna* \\ Civil \& Environmental Engineering Department \\ Tulane University \\ * formerly School of Civil Engineering graduate research assistant \\ and \\ Charles F. Scholer \\ Professor \\ School of Civil Engineering \\ Purdue University \\ Joint Transportation Research Program \\ Project No. C-36-46P \\ File No. 5-11-16 \\ SPR-2146 \\ Prepared in Cooperation with the \\ Indiana Department of Transportation and the \\ U.S. Department of Transportation \\ Federal Highway Administration
}

The contents of this report reflect the views of the author who is responsible for the facts and the accuracy of the data presented herein. The contents do not necessarily reflect the official views or policies of the Indiana Department of Transportation or the Federal Highway Administration at the time of publication. This report does not constitute a standard, specification, or regulation.

Purdue University

West Lafayette, Indiana 47907

October 2002 
TECHNICAL REPORT STANDARD TITLE PAGE

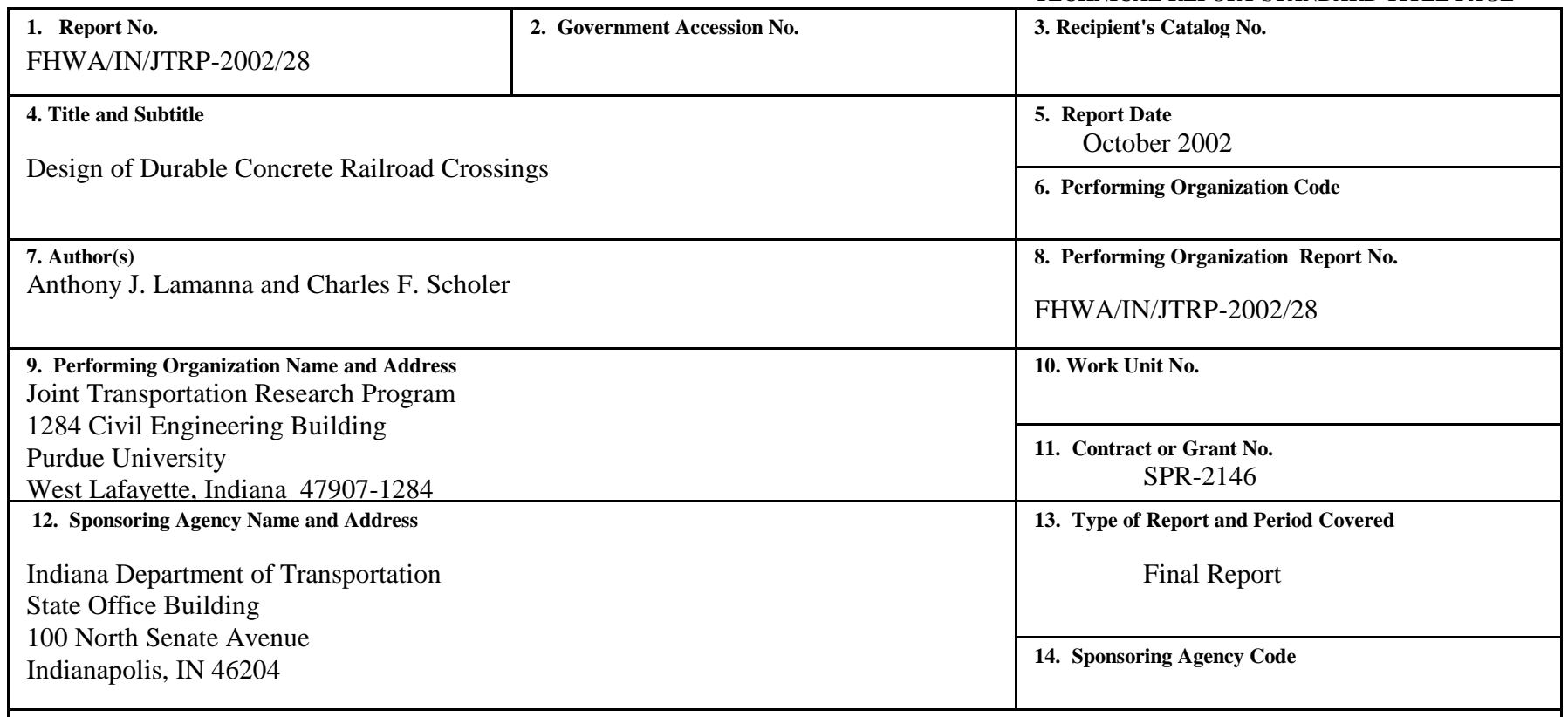

\section{Supplementary Notes}

Prepared in cooperation with the Indiana Department of Transportation and Federal Highway Administration.

\section{Abstract}

Existing precast concrete railroad crossings in the state of Indiana are experiencing too short a life expectancy. This study proposes methods that can be used to produce durable concrete railroad crossings with satisfactory rideability, durability, and longevity.

Thirty-two precast concrete railroad crossings were visited in central and northern Indiana. Failures were determined to belong to three major categories: structural capacity causes, environmental causes, and material property causes.

A concrete mix was evaluated at three different polyolefin fiber contents and without fibers. Beams were tested in flexure, and modulus of rupture and first crack deflection were recorded for each beam. Cylinders were cast for compressive testing and splitting tensile testing.

Modulus of rupture was increased by the addition of fibers. The spread in data was observed to increase with an increase in fiber content. Compressive strength and splitting tensile strength were increased slightly by the addition of fibers. Panels are currently being produced that utilize post tensioning. These panels are less likely to crack under extreme loading conditions. If a crack forms, it closes upon removal of the load.

\section{Key Words}

Concrete, railroad, durability, flexural strength, compressive strength, split tensile strength, precast, fibers,
18. Distribution Statement

No restrictions. This document is available to the public through the National Technical Information Service, Springfield, VA 22161
19. Security Classif. (of this report)

Unclassified
20. Security Classif. (of this page)

Unclassified

\begin{tabular}{c|c}
\hline 21. No. of Pages & 22. Price \\
106 & \\
\hline
\end{tabular}




\section{TECHNICAL Summary}

Technology Transfer and Project Implementation Information

\section{Design of Durable Concrete Railroad Crossings}

\section{Introduction}

A grade railroad crossing is the physical crossing of two different modes of transportation. The crossing creates a discontinuity in both the highway and the railroad line at the point of intersection, and in many cases the approaches must be altered. The crossing must transmit the highway traffic wheel loads and the rail loads through the crossing to the foundation structure. Rideability and durability are two concerns associated with a concrete railroad crossing. Conventional timber or rubber crossings deteriorate and become rough and even dangerous. Concrete surfaces can provide excellent long term performance, however many have failed. The goal of this project was to optimize the performance and life span of concrete crossings.

\section{Findings}

Modulus of rupture was significantly increased with the addition of polyolefin fibers. An increase in midpoint deflection accompanied this increased strength. The addition of polyolefin fibers to a precast concrete railroad crossing will impart increased flexibility and strength to the panel. The fibers will also serve to keep cracks from propagating and opening further in the case a crack does form. The addition of fibers, however, does not improve the properties of concrete enough to design a lay-in type panel of limited height using ordinary reinforced concrete. Post-tensioning used in conjunction with polyolefin fibers would allow a limited height panel to be designed adequately for both the strength and durability required.

\section{Implementation}

It is necessary that the ties supporting lay-in precast concrete panels be properly aligned so that the panel lies on all of the ties beneath it. If a tie is too low, it does not provide support, and if it is too high it may place undue stresses on fasteners.

When fasteners loosen, the panels are subjected to a rocking motion which causes further wear on the ties beneath it. The rocking motion continues to grow worse and can cause panels to crack.

For these reasons it is important to make sure the ties are aligned properly prior to installation. Lag screws should not be fastened to damaged ties, or ties that have been used to fasten previous panels. 


\section{Contacts}

For more information:

\section{Tommy Nantung}

Indiana Department of Transportation

Research Division

1205 Montgomery Road

P.O.Box 2279

West Lafayette, IN 47906

Phone: (765) 463-1521

Fax: (765) 497-1665
Indiana Department of Transportation

Division of Research

1205 Montgomery Street

P.O. Box 2279

West Lafayette, IN 47906

Phone: (765) 463-1521

Fax: (765) 497-1665

\section{Purdue University}

Joint Transportation Research Program

School of Civil Engineering

West Lafayette, IN 47907-1284

Phone: (765) 494-9310

Fax: (765) 496-1105 


\section{TABLE OF CONTENTS}

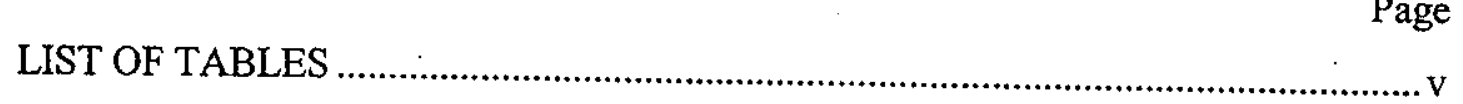

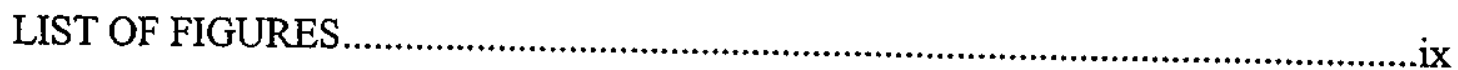

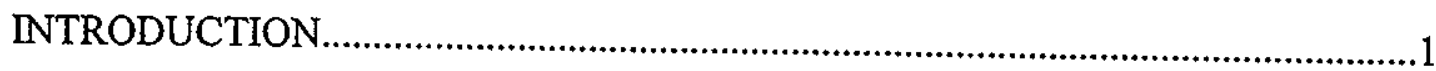

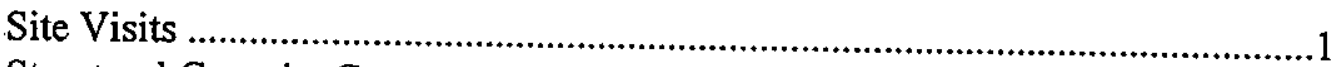

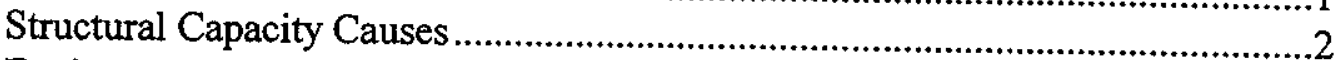

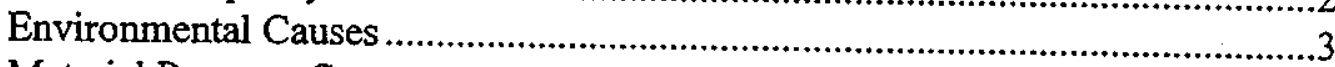

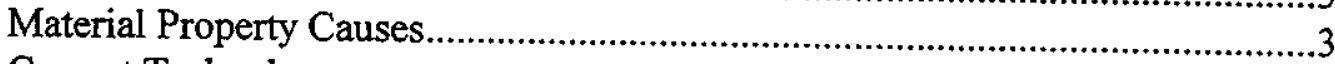

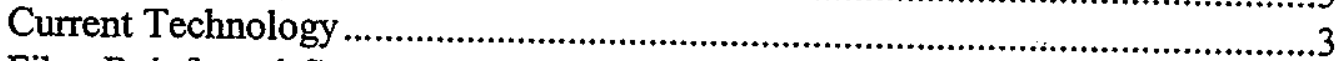

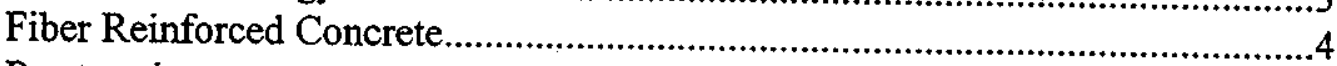

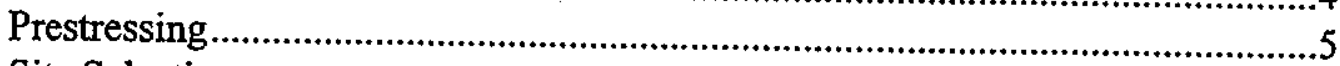

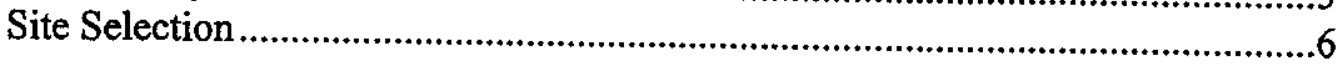

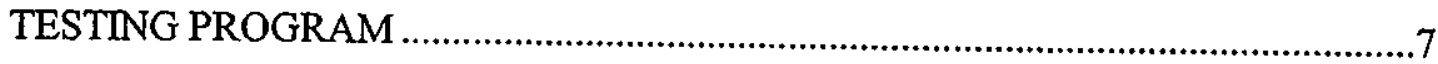

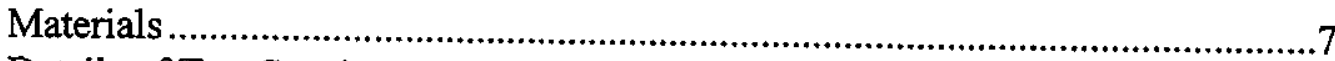

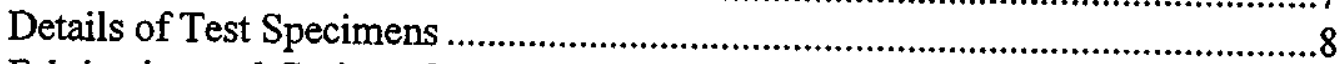

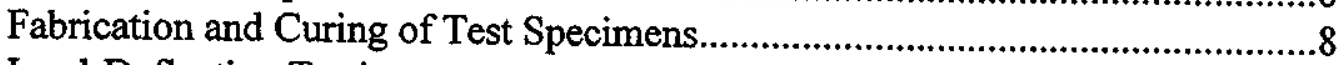

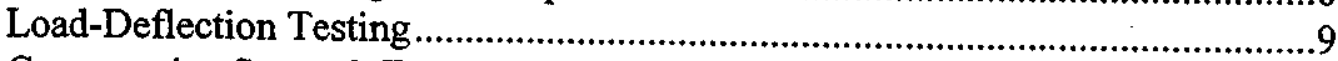

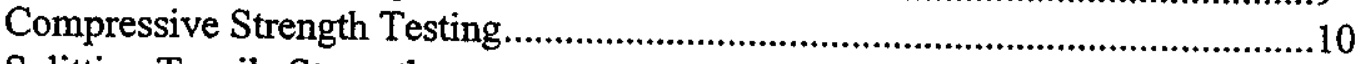

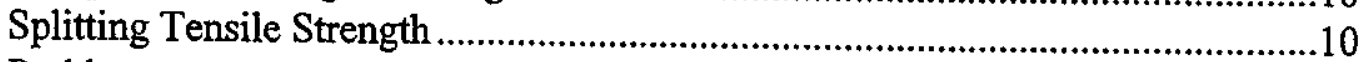

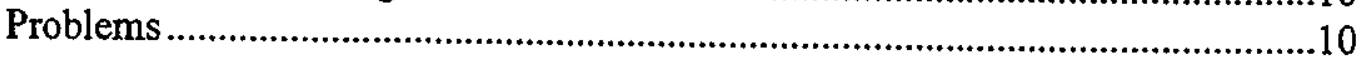

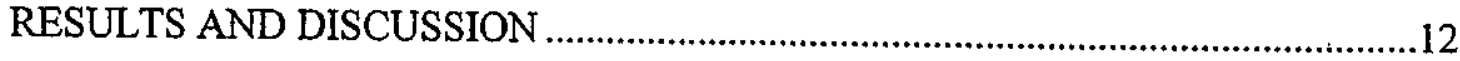

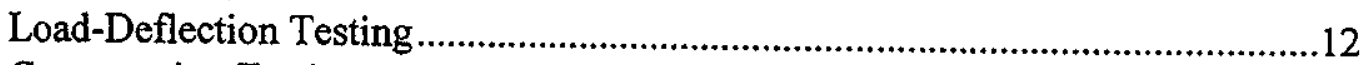

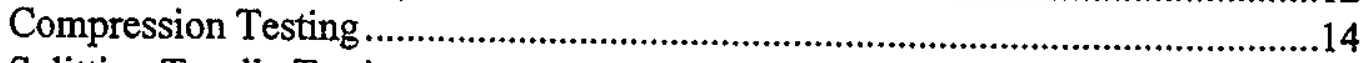

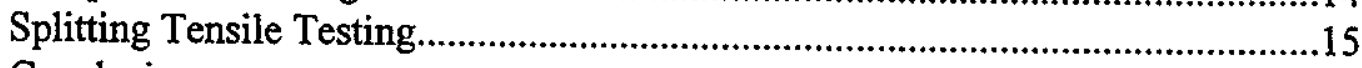

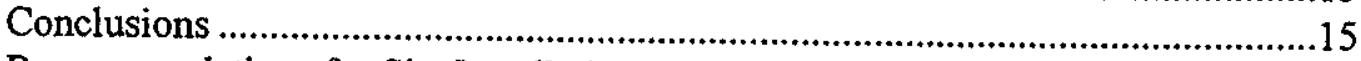

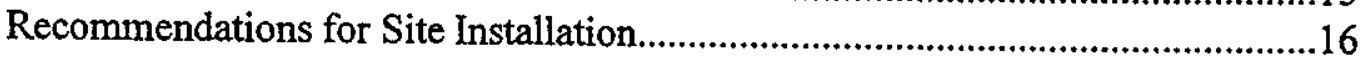

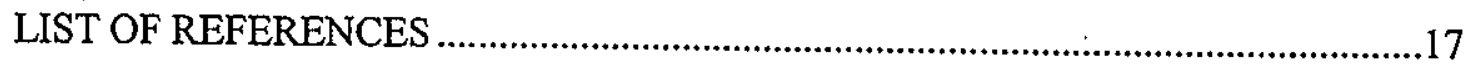

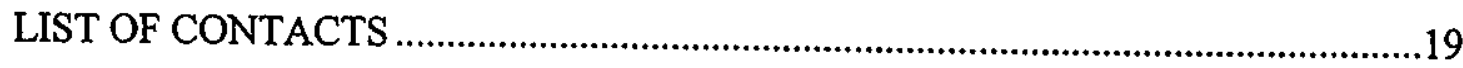




\section{APPENDICES}

Appendix A - Precast Concrete Railroad Crossings in the State of Indiana .........20 Appendix B - Minutes of Meetings ...............................................................24 Appendix C - Boswell Site Photographs .........................................................27

Appendix D - Test Results

Appendix E - Modulus of Rupture Load - Deflection Curves 


\section{LIST OF TABLES}

Table

1. Mechanical Properties of 3M Polyolefin Type 50/63 Fibers .7

Appendix

Table

A1 Precast Concrete Railroad Crossings in the State of Indiana .............................21

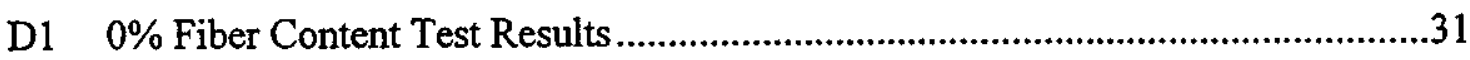

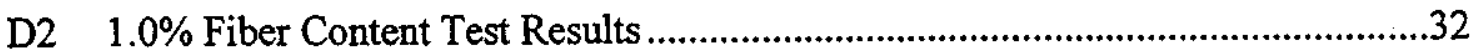

D3 1.33\% Fiber Content Test Results ......................................................................33

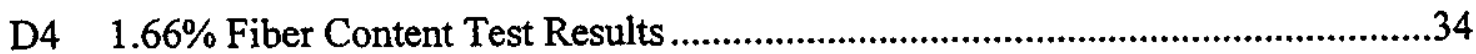

E1 Load Deflection Data for Specimen 0 - 2 - 1 .....................................................36

E2 Load Deflection Data for Specimen 0 - 2 - 2 ..................................................37

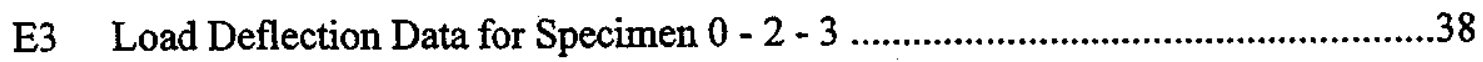

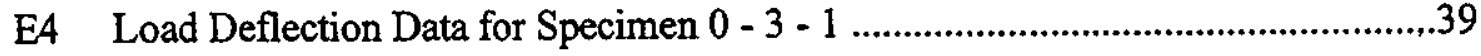

E5 Load Deflection Data for Specimen 0 - 3 - 2 ..................................................40

E6 Load Deflection Data for Specimen 0 - 3 - 3 ....................................................41

E7 Load Deflection Data for Specimen 0 - 4 - 1 ....................................................42

E8 Load Deflection Data for Specimen 0 - 4 - 2 ....................................................43

E9 Load Deflection Data for Specimen 0 - 4 - 3 ................................................44

E10 Load Deflection Data for Specimen 0 - 5 - 1 ....................................................45

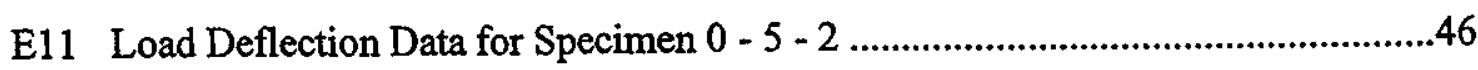

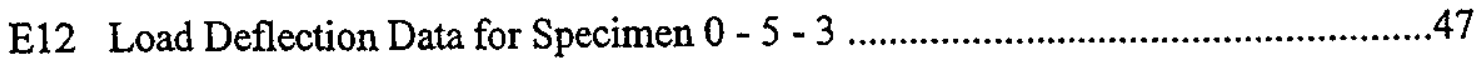

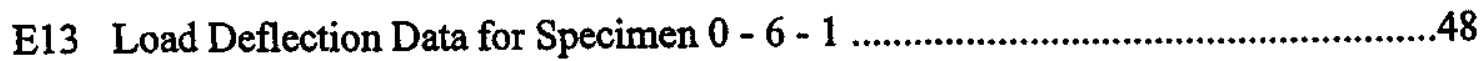

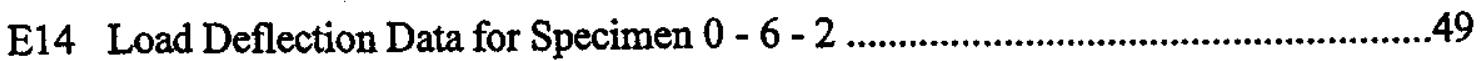


Appendix

Table

E15 Load Deflection Data for Specimen 0 - 6 - 3 ......................................................50

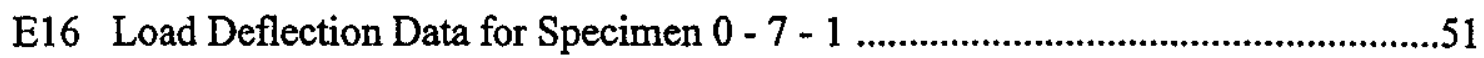

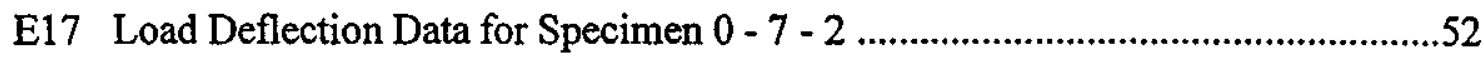

E18 Load Deflection Data for Specimen 0 - 7 - 3 ........................................................

E19 Load Deflection Data for Specimen 1.0 - 3 - 1 …….............................................54

E20 Load Deflection Data for Specimen 1.0 - 3 - 2 …...................................................55

E21 Load Deflection Data for Specimen 1.0 - 3 - 3 ...................................................56

E22 Load Deflection Data for Specimen 1.0 - 4 - 1 ......................................................57

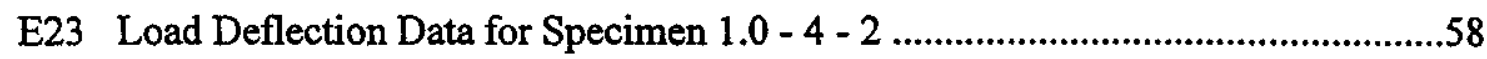

E24 Load Deflection Data for Specimen 1.0 - 4 - 3 ……............................................5

E25 Load Deflection Data for Specimen 1.0 - 5 - 1 ....................................................60

E26 Load Deflection Data for Specimen 1.0 - 5 - 2 ……..........................................61

E27 Load Deflection Data for Specimen 1.0 - 5 - 3 …….............................................62

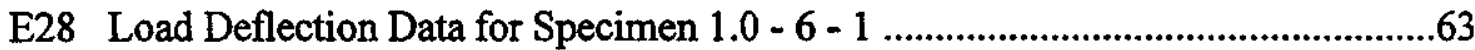

E29 Load Deflection Data for Specimen 1.0 - 6 - 2 ...............................................64

E30 Load Deflection Data for Specimen 1.0 - 6 - 3 .....................................................65

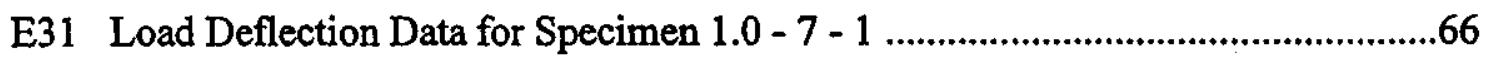

E32 Load Deflection Data for Specimen 1.0 - 7 - 2 .....................................................67

E33 Load Deflection Data for Specimen 1.0 - 7 - 3 .................................................68

E34 Load Deflection Data for Specimen 1.3 - 3 - 2 ……...............................................69

E35 Load Deflection Data for Specimen 1.3 - 3 - 3 …..................................................70

E36 Load Deflection Data for Specimen 1.3 - 4 - 1 .....................................................71

E37 Load Deflection Data for Specimen 1.3 - 4 - 2 .....................................................72

E38 Load Deflection Data for Specimen 1.3 - 4 - 3 ………….......................................73

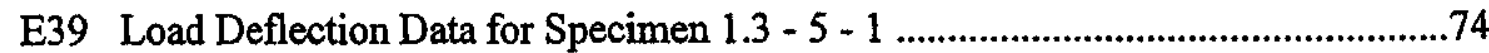

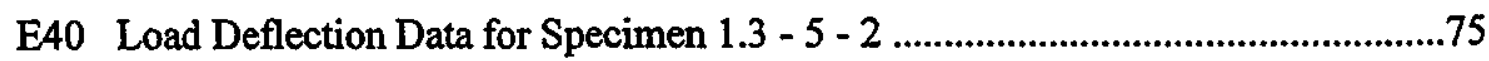

E41 Load Deflection Data for Specimen 1.3 - 6 - 1 …...............................................76 
Appendix

Table

E42 Load Deflection Data for Specimen 1.3 - 6 - 2 .77

E43 Load Deflection Data for Specimen 1.3 - 6 - 3 .78

E44 Load Deflection Data for Specimen 1.3 - 7 - 1 79

E45 Load Deflection Data for Specimen 1.3 - 7 - 2 .80

E46 Load Deflection Data for Specimen 1.3 - 7 - 3 .81

E47 Load Deflection Data for Specimen 1.3 - 8 - 1 . .82

E48 Load Deflection Data for Specimen 1.3 - 8 - 2 .83

E49 Load Deflection Data for Specimen 1.3 - 8 - 3 .84

E50 Load Deflection Data for Specimen 1.3 - 9 - 1 .85

E51 Load Deflection Data for Specimen 1.3 - 9 - 2 .86

E52 Load Deflection Data for Specimen 1.3 - 9 - 3 87

E53 Load Deflection Data for Specimen 1.6 - 1 - 2 .88

E54 Load Deflection Data for Specimen 1.6 - 3 - 1 .89

E55 Load Deflection Data for Specimen 1.6 - 3 - 2 .90

E56 Load Deflection Data for Specimen 1.6 - 3 - 2 91

E57 Load Deflection Data for Specimen 1.6 - 4 - 1 .92

E58 Load Deflection Data for Specimen 1.6 - 4 - 2 .93

E59 Load Deflection Data for Specimen 1.6 - 4 - 3 .94

E60 Load Deflection Data for Specimen 1.6 - 5 - 1 .95

E61 Load Deflection Data for Specimen 1.6 - 5 - 2 96

E62 Load Deflection Data for Specimen 1.6 - 5 - 3 .................................................97

E63 Load Deflection Data for Specimen 1.6 - 6 - 1 ..................................................98

E64 Load Deflection Data for Specimen 1.6 - 6 - 2 ….............................................99

E65 Load Deflection Data for Specimen 1.6 - 6 - 3 .................................................100

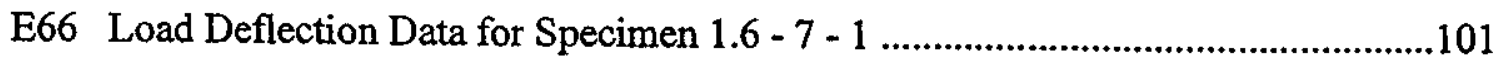

E67 Load Deflection Data for Specimen 1.6 - 7 - 2 …............................................102

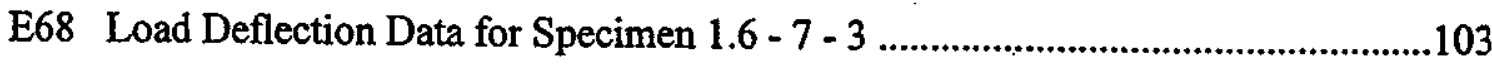


Appendix

Table

Page

E69 Load Deflection Data for Specimen 1.6 - 8 - 1

104

E70 Load Deflection Data for Specimen $1.6-8$ - 2 .................................................105

E71 Load Deflection Data for Specimen 1.6 - 8 - 3 .................................................106 


\section{APPENDICES}

Appendix A - Precast Concrete Railroad Crossings in the State of Indiana .........20 Appendix B - Minutes of Meetings ...............................................................24 Appendix C - Boswell Site Photographs .........................................................27

Appendix D - Test Results

Appendix E - Modulus of Rupture Load - Deflection Curves 


\section{LIST OF FIGURES}

\section{Figure}

1. MOR Data for Flexural Specimens

2. Flexural Testing Midpoint Deflection at Failure

Appendix

Figure

B1 Proposed SiteCross Section

C1 Southbound US 41 Signaling Gate .28

C2 Railroad Spikes Losening .28

C3 Replaced Panel

E1 Load Deflection Curve for Specimen 0 - 2 - 1 36

E2 Load Deflection Curve for Specimen 0 - 2 - 2 37

E3 Load Deflection Curve for Specimen 0 - 2 - 3 .38

E4 Load Deflection Curve for Specimen 0 - 3 - 1 .39

E5 Load Deflection Curve for Specimen 0 - 3 - 2 40

E6 Load Deflection Curve for Specimen 0 - 3 - 3 .41

E7 Load Deflection Curve for Specimen 0 - 4-1 42

E8 Load Deflection Curve for Specimen 0 - 4 - 2 43

E9 Load Deflection Curve for Specimen 0 - 4 - 3 .44

E10 Load Deflection Curve for Specimen 0 - 5 - 1 45

E11 Load Deflection Curve for Specimen 0 - 5 - 2 .46

E12 Load Deflection Curve for Specimen 0 - 5-3 47

E13 Load Deflection Curve for Specimen 0 - 6 - 1 .48

E14 Load Deflection Curve for Specimen 0 - 6 - 2 
Appendix

Table

E15 Load Deflection Curve for Specimen 0 - 6 - 3 .50

E16 Load Deflection Curve for Specimen 0 - 7 - 1 .51

E17 Load Deflection Curve for Specimen 0 - 7 - 2 .52

E18 Load Deflection Curve for Specimen 0 - 7 - 3 .53

E19 Load Deflection Curve for Specimen 1.0 - 3 - 1 .54

E20 Load Deflection Curve for Specimen 1.0 - 3 - 2 .55

E21 Load Deflection Curve for Specimen 1.0 - 3 - 3 .56

E22 Load Deflection Curve for Specimen 1.0 - 4 - 1 .57

E23 Load Deflection Curve for Specimen 1.0 - 4 - 2 .58

E24 Load Deflection Curve for Specimen 1.0 - 4 - 3 .59

E25 Load Deflection Curve for Specimen 1.0 - 5 - 1 .60

E26 Load Deflection Curve for Specimen 1.0 - 5 - 2 .61

E27 Load Deflection Curve for Specimen 1.0 - 5 - 3 62

E28 Load Deflection Curve for Specimen 1.0 - 6-1 63

E29 Load Deflection Curve for Specimen 1.0 - 6 - 2 64

E30 Load Deflection Curve for Specimen 1.0 - 6 - 3 .65

E31 Load Deflection Curve for Specimen 1.0 - 7 - 1 .66

E32 Load Deflection Curve for Specimen 1.0 - 7 - 2 67

E33 Load Deflection Curve for Specimen 1.0 - 7 - 3 68

E34 Load Deflection Curve for Specimen 1.3 - 3 - 2 .69

E35 Load Deflection Curve for Specimen 1.3 - 3 - 3 70

E36 Load Deflection Curve for Specimen 1.3 - 4 - 1 .71

E37 Load Deflection Curve for Specimen 1.3 - 4 - 2 .72

E38 Load Deflection Curve for Specimen 1.3 - 4 - 3 .73

E39 Load Deflection Curve for Specimen 1.3 - 5 - 1 .74

E40 Load Deflection Curve for Specimen 1.3 - 5 - 2 75

E41 Load Deflection Curve for Specimen 1.3 - 6 - 1 
Appendix

Table

E42 Load Deflection Curve for Specimen 1.3 - 6 - 2 …..........................................77

E43 Load Deflection Curve for Specimen $1.3-6$ - 3 …..............................................78

E44 Load Deflection Curve for Specimen 1.3 - 7 - 1 ................................................79

E45 Load Deflection Curve for Specimen 1.3 - 7 - 2 ….........................................8

E46 Load Deflection Curve for Specimen $1.3-7$ - 3 ................................................

E47 Load Deflection Curve for Specimen $1.3-8$ - 1 ...............................................82

E48 Load Deflection Curve for Specimen $1.3-8$ - 2 …..........................................83

E49 Load Deflection Curve for Specimen 1.3 - 8 - 3 …..............................................84

E50 Load Deflection Curve for Specimen 1.3 - 9 - 1 ................................................85

E51 Load Deflection Curve for Specimen 1.3 - 9 - 2 …...........................................86

E52 Load Deflection Curve for Specimen 1.3 - 9 - 3 ..............................................87

E53 Load Deflection Curve for Specimen 1.6 - 1 - 2 …..........................................88

E54 Load Deflection Curve for Specimen 1.6 - 3 - 1 ..............................................89

E55 Load Deflection Curve for Specimen 1.6 - 3 - 2 …...........................................90

E56 Load Deflection Curve for Specimen 1.6 - 3 - 2 f...........................................91

E57 Load Deflection Curve for Specimen 1.6 - 4 - 1 ..............................................92

E58 Load Deflection Curve for Specimen 1.6 - 4 - 2 …...........................................93

E59 Load Deflection Curve for Specimen 1.6 - 4 - 3 ….............................................94

E60 Load Deflection Curve for Specimen 1.6 - 5 - 1 ................................................95

E61 Load Deflection Curve for Specimen 1.6 - 5 - 2 ................................................96

E62 Load Deflection Curve for Specimen 1.6 - 5 - 3 ................................................97

E63 Load Deflection Curve for Specimen 1.6 - 6 - 1 ...............................................98

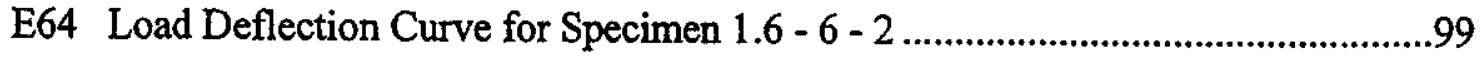

E65 Load Deflection Curve for Specimen 1.6 - 6 - 3 f.............................................100

E66 Load Deflection Curve for Specimen 1.6 - 7 - 1 ...................................................101

E67 Load Deflection Curve for Specimen 1.6 - 7 - 2 ...................................................102

E68 Load Deflection Curve for Specimen 1.6 - 7 - 3 ..................................................103 
Appendix

Table

E69 Load Deflection Curve for Specimen 1.6 - 8 - 1 ..................................................104

E70 Load Deflection Curve for Specimen 1.6 - 8 - 2 ...............................................105

E71 Load Deflection Curve for Specimen 1.6 - 8 - 3 ................................................106 


\section{INTRODUCTION}

A grade railroad crossing is the physical crossing of two different modes of transportation. The crossing creates a discontinuity in both the highway and the railroad line at the point of intersection, and in many cases the approaches must be altered. The crossing must transmit the highway traffic wheel loads and the rail loads through the crossing to the foundation structure. Rideability and durability are two concerns associated with a concrete railroad crossing. Conventional timber or rubber crossings deteriorate and become rough and even dangerous. Concrete surfaces can provide excellent long term performance, however many have failed. The goal of this project was to optimize the performance and life span of concrete crossings.

\section{$\underline{\text { Site Visits }}$}

A list of all precast concrete crossings in Indiana was provided by INDOT. Starting in the Fall of 1997, visits were made to 37 of the crossings on the list. Most of the sites were in central and northern Indiana. A complete listing of the crossings is located in table A-1 in Appendix A. Sites that were visited and inspected are clearly marked. Sites were checked for cracks perpendicular to the long side of the panels. Surface scaling, movement of panels under traffic load, and bolts with the head sheared off were also found at some crossings. Five of the sites visited had been replaced with rubber crossings.

Of the 32 concrete crossings visited, 6 had panels which exhibited significant amounts of vertical movement while subject to vehicular traffic loads. During certain site visits there was no vehicular traffic, so there may be more crossings containing panels 
that move. It is also important to note that all the panels which moved significantly contained cracks perpendicular to the long edge.

19 of the sites contained one or more panels which exhibited cracks perpendicular to the long edge. These cracks spanned the entire width of the panel. 15 crossings contained one or more panels which showed severe surface scaling. In some cases the surface scaling was so severe that up to $50 \mathrm{~mm}$ ( 2 inches) of the surface concrete was spalled off. Four of the crossings contained bolts with heads sheared off.

From studying many crossings in Indiana, potential causes leading to the observed problems vary, but can be placed into three groups: structural capacity related causes, performance related causes, and material property causes.

\section{Structural Capacity Causes}

Concrete slabs at a railroad crossing are normally under a complicated loading scheme. Vehicle wheel loads produce a combined action of bending and shear, and the passing of a train induces a wave motion in the tracks. Non-uniform support beneath the slab also adds difficulties in design. The panel may not rest on all ties that it spans, and is attached to some ties with lag screws. This results in an unknown loading condition for each panel.

The slab thickness is limited by the height of the railroad tracks, which is usually 6 to 8 inches. This small slab thickness cannot provide enough carrying capacity to resist the action of the wheel loads and poses problems to the design of reinforcement. For example, if the standard $38 \mathrm{~mm}$ (1 $1 / 2$ inches) cover is used, the reinforcing steel is placed extremely close to the neutral axis, where it contributes very little to the strength of the member. 


\section{Environmental Causes}

Rideability principally depends on roughness as perceived by the highway users. Roughness arises from cracked slabs and failure due to the different stiffnesses required by the two modes of transportation. The railroad is designed to flex under the weight of the heavy trains, whereas the highway is designed to be rigid under the loading of highway vehicles. A highway surface is impermeable and constructed with a crown so that rainfall runs off to the edges and does not saturate the base. A railway is flat over short distances and is designed so that rainfall filters down through the coarse ballast.

\section{Material Property Causes}

Durability in freezing and thawing conditions is based on the properties of the concrete used in the crossing. Poor properties result in scaling, spalling, and cracking. As a result of these, poor rideablilty and poor durability are sometimes experienced at concrete railroad crossings. When cracking occurs, water and dissolved de-icing salts reach the reinforcing steel and speed up the corrosion process. The expansive corrosion products further increase cracking of the concrete crossing. Railroad companies are very aware of the risk of a severely cracked concrete section popping up and derailing a train.

Concrete has a low tensile strength and a low strain at failure. The tensile strength is low because concrete contains many microcracks. These microcracks propogate swiftly under applied stresses, not allowing large deformations before failure. These intrinsic properties of concrete can be altered by adding fibers.

\section{Current Technology}

There are several types of precast concrete railroad crossings available in the market. They fall into two catagories: "platform" and "lay-in." Platform type crossings 
consist of one large cross section that spans beneath the rails and eliminates the need for ties underneath the crossing. This type is more expensive to install, and it increases the stiffness of the railroad more than the other type. The lay-in type consists of concrete panels that are set on top of the ties and are attached using lag screws. The lay-in crossings are cheaper to install and do not significantly reduce the track flexibility, but the height limitation creates design problems. Lay-in type crossings also reduce the amount of traffic control needed during installation.

Lay-in type crossings are preferred by railroad companies because they do not significantly reduce the flexibility of the track at the grade intersection. The major problem with these precast members is their tendancy to crack. Further deterioration is accelerated once a crack is opened as water and foreign elements can enter through the crack.

\section{Fiber Reinforced Concrete}

Durable concrete should ideally be resistant to crack formation and propagation. Realistically, concrete's low tensile strength and brittle nature make it a material which is prone to cracking. The addition of fibers provides an energy absorbing capacity that can hold the concrete together during fracture. Since the 1960 s, fiber reinforced concrete (FRC) has been used to increase the durability of transportation structures (Ozyildirim 1997).

Cracks allow water and solutions to penetrate the concrete, which leads to further deterioration of the concrete. Alkali-aggregate reactions, corrosion of reinforcement, freezing-thawing, and sulfate attack may be magnified with this increased permeability in the concrete matrix. These problems produce expansive materials within the concrete and result in further cracking and deterioration of the concrete.

Fibers stop crack propogation, which results in smaller cracks. Smaller cracks create a lower permeablility and an increased ultimate cracking strain (Ramakrishnan 1995). Steel fibers have typically been used to improve the properties of hardened 
concrete. Fibers have been used in beams subjected to impact loading in instrumented drop-weight and Charpy type systems. It was reported that the total energy absorbed by fiber concretes can be as much as 40-100 times more than that for unreinforced beams (Ramakrishnan 1997).

Synthetic fibers are typically used to reduce plastic shrinkage cracking in fresh concrete. While synthetic fibers do not corrode, conduct, or create harmful protrusions, they cannot be used at high volume contents because they cause the fresh concrete to ball up in the mixer. This prevents the concrete from mixing properly. Polyolefin fibers are much larger than typical synthetic fibers and can be used in higher volume percentages than previously used synthetic fibers without balling.

\section{Prestressing}

Prestressing concrete involves applying loads, prior to applying the service loads, in order to eliminate or reduce the tensile loads that would occur. By improving this service load behavior and utilizing high strength materials, smaller and lighter members may be used.

Prestressed concrete members are either pretensioned or post-tensioned. Pretensioned concrete members are made by stretching the tendons before the concrete is placed. The concrete is allowed to harden, and when it reaches the required strength, the stretching force is released and the force is transfered from the steel to the concrete through the bond. Post-tensioning of members is accomplished by jacking the unbonded tendons against the ends of the member after the concrete is hardened.

Lay-in precast concrete railroad crossing panels are too short for pretensioning. There is not enough length to develop the bond between the steel prestressing tendon and the concrete. Post-tensioning the panel would allow the entire length between the end anchorage plates to benefit from the prestressing force. If the panels were longer, heavier equipment would be needed to install them. 
If a large enough load occurs on a prestressed member, a crack occürs. When the load is removed, the compressive force in the prestressing tendon forces the crack together. This prevents intrusion of harmful elements, which cause further deterioration of the concrete around the crack.

The inherent qualities of precast and prestressed concrete make it ideal for lay-in railroad crossings. The increased corrosion resistance, fire resistance, durability, and fast installation have even been used as a good alternative to timber railroad ties (PCA 1992).

\section{Site Selection}

Of several sites that were inspected, the crossings on US 41 in Boswell and US 421 in Reynolds were potential sites for a test of full scale panels. The Reynolds crossing has one lane of traffic in each direction, and is a relativly low traffic road. The Boswell crossing has two lanes of traffic in each direction. Lay-in precast concrete panels used in the past at the Boswell crossing have failed in a short amount of time.

The southbound lanes are of particular importance as they carry a high volume of truck traffic at high speeds. The presence of a quarry to the north of the crossing means heavier wheel loads created by the loaded trucks heading south than the unloaded trucks traveling north. The average speed of truck traffic passing the crossing is about $115 \mathrm{~km} / \mathrm{h}$ (72 mph), according to INDOT officials.

The high speed of the traffic creates a severe loading on the panels and the rails themselves. Over time, the rails become lose as the spikes pull out from the timber ties. These rails then "flap" up and down when a highway vehicle crosses them. The rails were refastened to the ties in mid August, but by the September 18th meeting at the site, the rails were loose again.

Minutes of important meetings are included in Appendix B. Photographs of the US 41 site in Boswell are in Appendix C. 


\section{TESTING PROGRAM}

\section{$\underline{\text { Materials }}$}

Type I Lonestar Portland Cement from Greencastle, Indiana was used in making all test specimens. It was stored in the original $42.63 \mathrm{~kg}(94 \mathrm{lb})$ cement sacks in a dry room. The concrete mixtures were designed to produce compressive strengths of 41.37 Mpa (6000 psi) at 28 days. A workability as shown by a $76.2 \mathrm{~mm}$ ( 3 inch) slump in the non fiber reinforced concrete mix was chosen. The addition of fibers eliminated the slump. The cement used was ground very finely so that the strengths. of the $152.4 \mathrm{~mm}$ (6 inch) cylinders reached strengths upwards of $55.16 \mathrm{Mpa}$ ( $8000 \mathrm{psi})$ at 14 days. Results are reported for each specimen.

The fibers were type 50/63 polyolefin fibers manufactured by $3 \mathrm{M}$. The fibers were $50.0 \mathrm{~mm}$ ( 2 inches) long and $0.63 \mathrm{~mm}$ ( 0.025 inches) in diameter. Individual fibers were wrapped together in approximately $50 \mathrm{~mm}$ ( 2 inch) diameter bundles and packaged in boxes of $11.3 \mathrm{~kg}$ (25 lbs.). The physical properties are listed

Table 1 : Mechanical Properties of 3M Polyolefin Type 50/63 Fibers Specific Gravity $\quad 0.91$ Tensile Strength $\quad 275 \mathrm{MPa}$ (40,000 psi)

Modulus of Elasticity $2647 \mathrm{MPa}$ $(384,000$ psi)

Elongation at Break $15-17 \%$ Ignition Point $596^{\circ} \mathrm{C}\left(1100^{\circ} \mathrm{F}\right)$ Melt Point $160^{\circ} \mathrm{C}\left(320^{\circ} \mathrm{F}\right)$ 


\section{Details of Test Specimens}

All test beams were $152.4 \mathrm{~mm} \times 152.4 \mathrm{~mm} \times 533.4 \mathrm{~mm}$ (6 inch $\times 6$ inch $\times 21$ inch) and cylinders $152.4 \mathrm{~mm}$ (6 inch) diameter and $304.8 \mathrm{~mm}$ (12 inch) height. All specimens were made in accordance with ASTM 192 M - 95. The specimens were labeled with three numbers separated by dashes. The first number indicates the volume percentage of fiber reinforcing. The second number indicates the batch number from which the specimen was cast. The last number indicates the specimen number of that particular batch. For example, beam $1.6-5$ - 2 indicates that the specimen has a 1.66 volume percentage of fiber reinforcing, was cast from batch 5 , and was the second beam cast. Three beams were cast from each batch in most cases.

\section{Fabrication and Curing of Test Specimens}

The concrete was mixed in a 1.5 cubic foot batch mixer. All materials were measured by weight. The coarse and fine aggregates were mixed with the cement for one minute before the addition of water. The concrete was allowed to mix two minutes before adding the fibers. The fibers were sprinkled into the mixer over approximately two more minutes, and the concrete was then mixed for an additional minute once all the fibers had been added.

Multiple use steel forms were used for making beams and plastic forms were used for making cylinders. The forms were oiled using form release oil prior to batching. Concrete was placed into the forms using a metal scoop and then vibrated using a $25 \mathrm{~mm}$ (1 inch) diameter electric immersion vibrator. Additional concrete was added until flush with the top of the form. An oiled steel plate was used to cap the beam specimens.

Cylinders were cast in three equal lifts. Each lift was vibrated with a $25 \mathrm{~mm}$ (1 inch) diameter electric immersion vibrator. The top surface of the cylinders was struck with a metal bar and any protruding fibers were removed. The first few attempts at 
striking off and smoothing exposed surfaces proved difficult, but after working with the fibers it became easier. The cylinders were then capped.

The concrete was allowed to cure for 24 hours. The forms were stripped 24 hours later and the specimens were labeled and placed into a moist room. The specimens were rinsed in tap water if there was an obvious excess of form oil present. The steel forms were then cleaned with a steel brush for the next batch of beams. After two weeks, the two weeks stock of beams was restacked so that the older beams were on the top for easy access prior to testing. Cylinders were placed on wooden shelves in the moist room for easy access.

\section{Load-Deflection Testing}

Beams, spanning 18 inches, were tested in flexure in sets of three at 28 days. During the flexure test, load on and deflection of the beam were recorded to establish a load-deflection history.

The linear voltage differential transducer (LVDT) was placed beneath the center of the bottom testing fixture to measure the deflection. The beam was then centered on the reaction frame. The top frame was placed so as to apply load at the third points on the top of the beam. The reaction frames do not allow translation at the supports, but do allow rotation. The SATEC testing machine was programmed to stop at $2224 \mathrm{~N}(500 \mathrm{lb})$ intervals for 30 seconds so that the LVDT reading could be recorded. The machine was programmed to stop at 20 set points. Fewer points were recorded below $13.34 \mathrm{kN} \mathrm{(4000}$ lb) due to settlement in the supports. The loading was performed at a constant ram speedof $0.508 \mathrm{~mm}$ ( $0.02 \mathrm{inch})$ per minute. 


\section{Compressive Strength Testing}

Cylinders were tested at 14 days of age to determine the compressive strength. After continuous curing in a moist room at a constant temperature, the cylinders were tested using end caps.

\section{Splitting Tensile Strength}

Cylinders were tested at 14 days of age to determine the tensile strength of the concrete. The cylinders were tested on their side at a loading rate of $66.72 \mathrm{kN}(15,000 \mathrm{lb})$ per minute, as per ASTM standard C 496 - 96.

\section{Problems}

There were many problems encountered both while preparing to test and during the testing phase. Most of these problems were due to lack of equipment or improper functioning of equipment.

The first problem was lack of a proper testing machine and data acquisition computer. While planning testing in January 1998, the person working on the testing machine and data aqusition system said it would be ready in March. Samples were prepared to reach 28 day strength two weeks after the testing apparatus was scheduled to be completed. The testing machine was not ready when the samples reached 28 days. In April the system was finished, but it was extremely unreliable, only recording data occasionally.

The samples were tested without a computer data aqusition system. However, the testing machines had an internal safety device which ended a test when the computer sensed a release of load. Similar to the data aqusition system, this safety device was unreliable and allowed a small percentage of beams to be tested past first crack load. 
The ends of the first set of beams were sawed into $152.4 \mathrm{~mm}$ (6 inch) cubes so that they could be tested in compression. However, these cubes could not be broken in the $1,112 \mathrm{kN}$ (250 kip) hydraulic compression tester. The only available machine in the School of Civil Engineering that is capable of a load greater than 250 kips is located in the structures lab, and it frequently has a full scale beam loaded in it. These cubes could therefore not be tested.

The same type of problem was encountered when testing the $152.4 \mathrm{~mm}$ (6 inch) cylinders in compression. At 14 days, they cylinders came close to the maximum capacity of the machine, breaking at about $1,045 \mathrm{kN}$ (235 kips). Due to lack of a testing machine capable of more than $1,112 \mathrm{kN}$ (250 kips), the cylinders were not saved as planned to be tested at 28 days. $152.4 \mathrm{~mm}$ ( $6 \mathrm{inch})$ cylinders were used instead of smaller cylinders because of the $50.0 \mathrm{~mm}$ ( 2 inch) length of the polyolefin fibers. 


\section{RESULTS AND DISCUSSION}

Test results are presented in Appendix D in tabular form for each volume percent of fiber content. Average and standard deviations are given for flexural tests, compression tests, and splitting tensile tests.

\section{Load - Deflection Testing}

When the load-deflection data was graphed, the slope varied until the load reached about $17.79 \mathrm{kN}$ ( 4000 pounds). This was due to the supports in the testing it was apparent that there was a fair amount of settlement in the supports of the apparatus. At higher loads, the load deflection curve becomes linear. In order to correct for this, a linear regression was performed on the linear upper portion of the load-deflection graph, and the $\mathrm{x}$ intercept was calculated and taken to be the new origin, $O^{\prime}$. Appendix $E$ contains the load-deflection curves for all of the flexure specimens.

Many of the beams failed with a center crack straight across the base. A few failed with the crack slightly skewed, indicating a torsional loading. This torsion is most likely a result of a misaligned load frame. These added tosional loads have a minute effect on elements in the stress field and less effect on the deflection (Tatro 1985).

Visual inspection of the failure surfaces shows a high variability in the fiber distribution. The modulus of rupture was increased $5.6 \%, 9.2 \%$, and $13.4 \%$ for the addition of fibers by $1.00 \%, 1.33 \%$, and $1.66 \%$ by volume. Figure 1 shows the average modulus of rupture for each series of beam specimens. Higher fiber contents lead to more fibers in the tensile zone of the beam. The additional fibers in the tensile zone assist the concrete matrix in carrying a higher tensile load, increasing the modulus of rupture. 


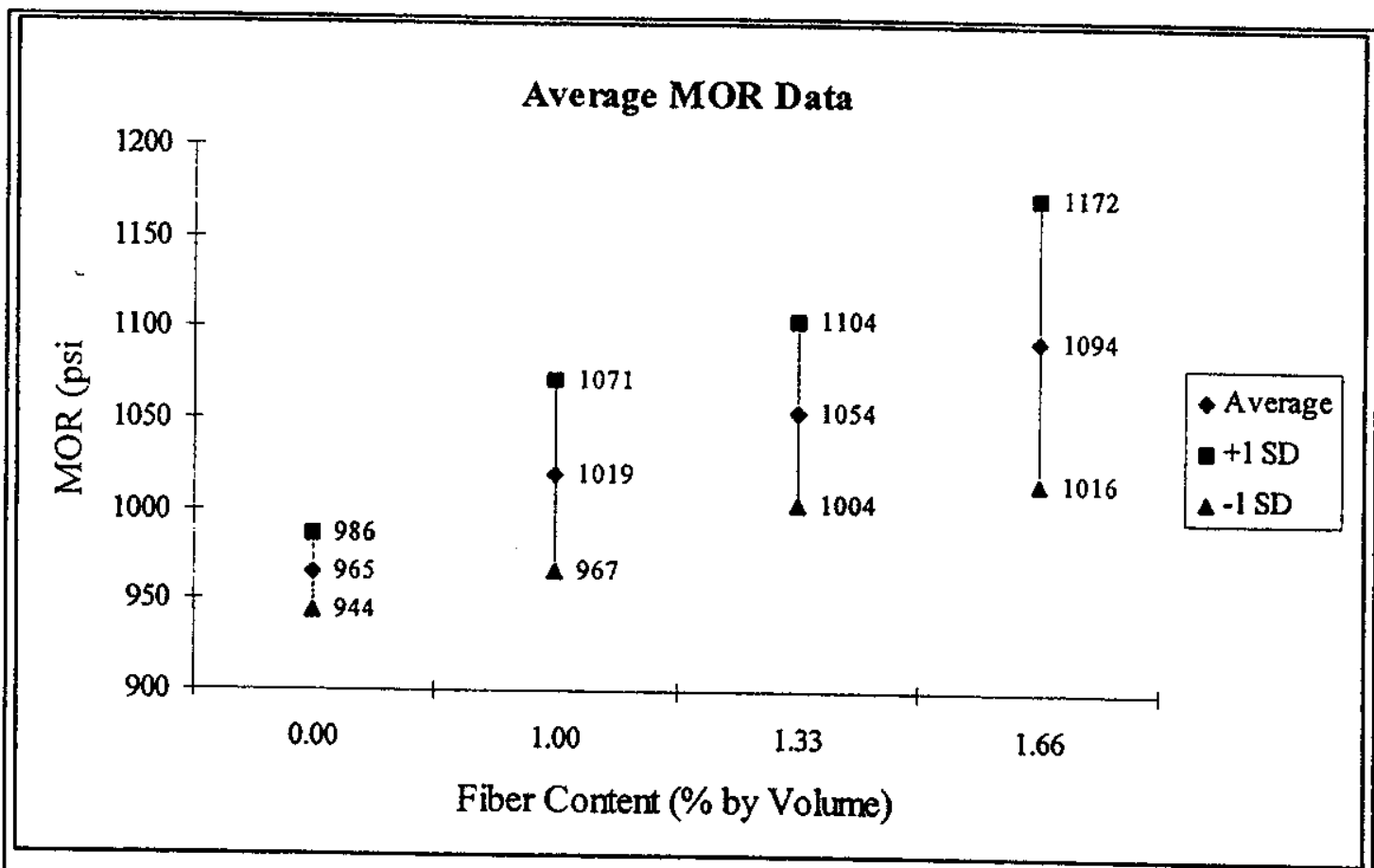

Figure 1: MOR data for flexural specimens.

Another trend observed in Figure 1 is the increase in the standard deviations. As the fiber contents increase, the standard deviations increase. Small changes in the concentration and alignment of fibers in the tensile zone can result in large variations in the load capacity. Low fiber concentrations and nonpreferential fiber alignment in the tensile zone can result in a low modulus of rupture.

The modulus of rupture is calculated assuming a linear stress distribution across the height of the beam. In reality the stress is not linear, and the actual ultimate strength is always lower than the modulus of rupture. The random distribution and alignment of the fibers further modifies the stress distribution, particularly in the tensile zone, which contributes to the increased deviation in the results. 


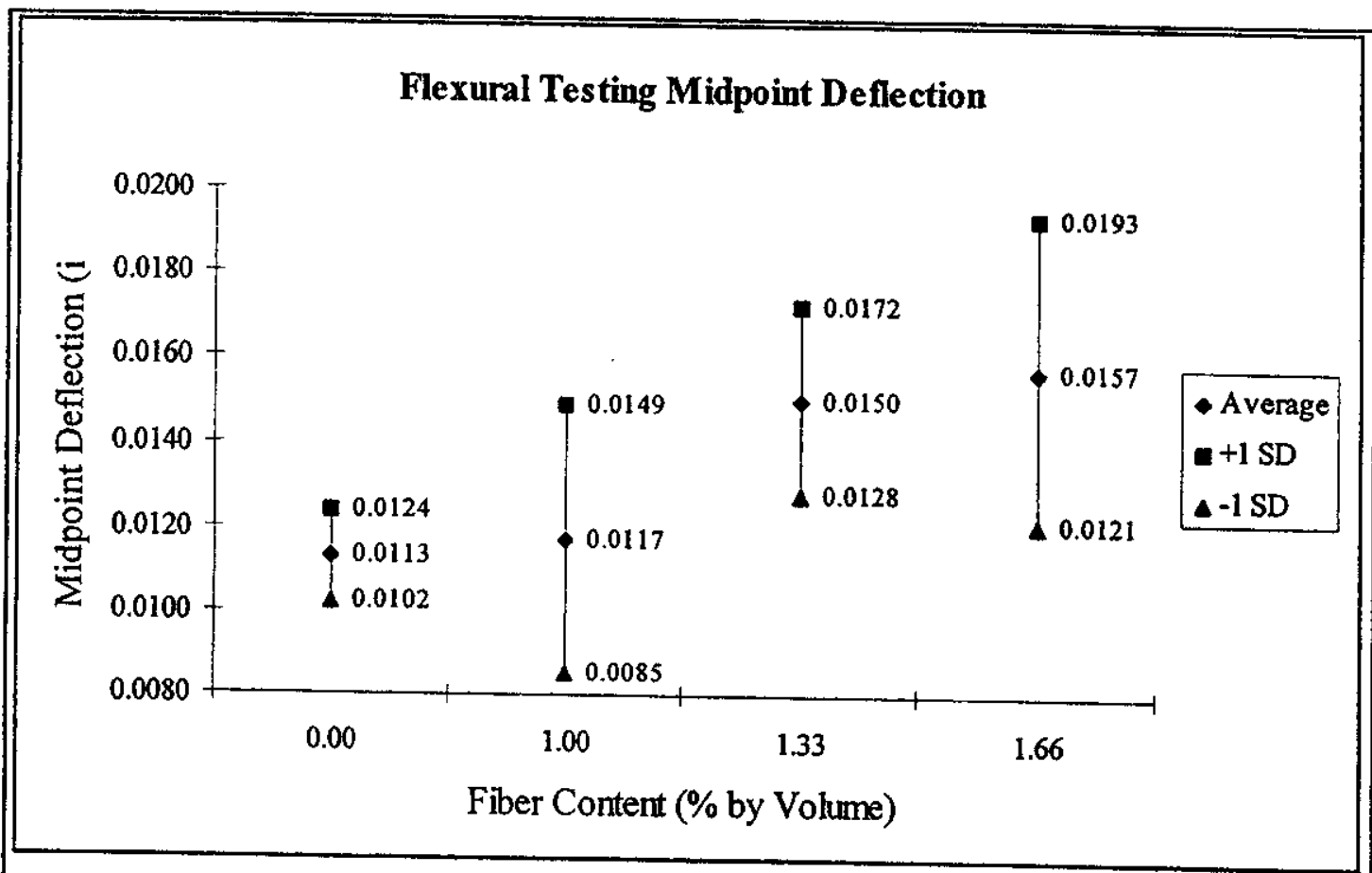

Figure 2: Flexural Testing Midpoint Deflection at Failure

Data indicates that the addition of fibers increases the ultimate midpoint deflection of the third point specimens. As expected the plain concrete specimens had a relatively small standard deviation, while the specimens containing fibers had significantly larger deviations. Since strains are related to the stresses within the material, it is not suprising that the deviations tend to be larger for the concrete containing fibers.

\section{Compression Testing}

The addition of polyolefin fibers to the concrete matix increased the compressive strength slightly. The addition $1.00 \%, 1.33 \%$ and $1.66 \%$ fibers by volume increased the compressive strength by $0.9 \%, 1.4 \%$, and $3.5 \%$ respectively. While these increases are minimal, it is important to note that the stiffness of a concrete is generally related to its compressive strength. This generalization does not apply in this case as the deflection of the third point specimens increases with the increasing fiber content. The increasing 
modulus of rupture creates the potential to deflect through a higher load level, creating a higher deflection at failure.

\section{Splitting Tensile Testing}

The precise identification of the first crack is difficult to determine in a splitting tensile test "without strain gages or other sophisticated means of crack detection, such as acoustic emission or laser holography" (ACI Committee 544). The polyolefin fiber reinforced concrete samples failed with an audible cracking sound. When the load was removed, the cracks were not easily visible. Upon closer inspection, hairline cracks could be seen crossing the ends of the cylinder, dividing them almost exactly in half. After testing, specimens could not be pried apart along this failure crack.

The splitting tensile strength of the mixes was increased by $0.3 \%, 4.9 \%$, and $7.2 \%$ with the addition of fibers by $1.00 \%, 1.33 \%$, and $1.66 \%$. While these increases are less than the increases in the modulus of rupture, they follow the same general trend.

\section{Conclusions}

Modulus of rupture was significantly increased with the addition of polyolefin fibers. An increase in midpoint deflection accompanied this increased strength. The addition of polyolefin fibers to a precast concrete railroad crossing will impart increased flexibility and strength to the panel. The fibers will also serve to keep cracks from propagating and opening further in the case a crack does form.

The addition of fibers, however, does not improve the properties of concrete enough to design a lay-in type panel of limited height using ordinary reinforced concrete. Post-tensioning used in conjunction with polyolefin fibers would allow a limited height panel to be designed adequately for both the strength and durability required. 


\section{Recommendations for Field Installation}

It is necessary that the ties supporting lay-in precast concrete panels be properly aligned so that the panel lies on all of the ties beneath it. If a tie is too low, it does not provide support, and if it is too high it may place undue stresses on fasteners.

When fasteners loosen, the panels are subjected to a rocking motion which causes further wear on the ties beneath it. The rocking motion continues to grow worse and can cause panels to crack.

For these reasons it is important to make sure the ties are aligned properly prior to installation. Lag screws should not be fastened to damaged ties, or ties that have been used to fasten previous panels. 


\section{LIST OF REFERENCES}

ACI Committee 544, "Measurement of Properties of Fiber Reinforced Concrete," $A C I$ Materials Journal, Vol. 85 No. 6, Nov-Dec 1988, pp 583-593.

Lok, Tat-Seng and Pei, Jin-Song, "Flexural Behavior of Steel Fiber Reinforced Concrete," Journal of Materials in Civil Engineering, Vol. 10 No. 2, May 1998, pp 86-97.

Naaman, Antoine E., "New Fiber Technology," Concrete International, Vol. 20 No. 7, July 1998 , pp 57-62.

Nilson, Arthur H., Design of Prestressed Concrete, $2^{\text {nd }}$ ed., John Wiley \& Sons, New York, New York, 1987.

Ozyildirim, Celik, Moen, Christopher and Hladky, Shannon, April 1997, "Investigation of Fiber-Reinforced Concrete for Use in Transportation Structures," Report No. FHWA/VTRC 97-R15, Virginia Department of Transportation, Richmond, VA, 19 pages.

PCI Industry Handbook Committee, PCI Design Handbook, Precast and Prestressed Concrete, $4^{\text {th }}$ ed., Precast / Prestressed Concrete Institute, Chicago, II, 1992.

Ramakrishnan, V, "Evaluation of Non-Metallic fiber Reinforced Concrete in PCC Pavements and Structures," Study SD94-04-I, South Dakota Department of Transportation, Pierre, SD, Sept 1995.

Ramakrishnan, V, "A New Material (Polyolefin Fiber Reinforced Concrete) for the Construction of Pavements and White-Topping of Asphalt Roads," Sixth International Purdue Conference on Concrete Pavement Design and Materials for High Performance, Proceedings Volume 1, Nov 18 - 21, 1997, pp 119-130.

Richards, Hoy A. et al., comps. Synthesis of Highway Practice 250: Highway-Rail Grade Crossing Surfaces, Washington DC: National Academy Press, 1998. 
Sprinkel, Michael, et al., "Pavement Overlays in Virginia." Sixth International Purdue Conference on Concrete Pavement Design and Materials for High Performance, Proceedings Volume 2, Nov 18 - 21, 1997, pp 217-229.

Tatro, Stephen Brent, "The Effect of Steel Fibers on the Toughness Properties of Large Aggregate Concrete," Master of Science in Civil Engineering Thesis, December 1985, pp 113.

Zollo, Ronald F. and Hays, Carol D., "A Habitat of Fiber Reinforced Concrete," Concrete International, Vol. 16 No. 6, June 1994, pp 23-26. 
LIST OF CONTACTS 


\section{LIST OF CONTACTS}

Name

Hohl, Fred

Hull, Steve

Nantung, Tommy

Shaw, Larry

Scholer, Charles

Baker, James

Brookhart, Clint

Burleson, Lon

McDonald, Cliffton
Affiliation

Phone

INDOT Railroad Unit

INDOT

INDOT Research

INDOT

Purdue University

Star Track

Star Track

Star Track

$3 \mathrm{M}$
(317)232-5301

(317)232-5340

(765)463-1521

(317)233-3701

(765)494-5017

(303)791-1120

(303)791-1120

(708)839-2676

(651)736-7390 
APPENDIX A - LIST OF PRECAST CONCRETE RAILROAD CROSSINGS 
Table A1: Precast Concrete Railroad Crossings in the State of Indiana

\begin{tabular}{|c|c|c|c|c|c|c|c|c|}
\hline Agency & Road Name & Surface $\$$ & 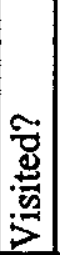 & & & & 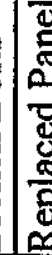 & Comments \\
\hline INDOT & SR109 & 235,100 & & & & & & \\
\hline INDOT & SR 45 & 100,608 & & & & & & \\
\hline INDOT & SR 64 & 96,715 & & & & & & \\
\hline INDOT & SR 15 & 154,400 & $\mathrm{Y}$ & & & & & Replaced with rubber \\
\hline INDOT & SR 22 & 152,949 & $\mathrm{Y}$ & & $\mathrm{X}$ & $\mathrm{X}$ & & \\
\hline INDOT & US 31 & 180,390 & $\mathrm{Y}$ & & & & & Replaced with rubber \\
\hline INDOT & US 50 & 55,446 & & & & & & \\
\hline INDOT & US 50 & 190,889 & & & & & & \\
\hline INDOT & SR 55 & 49,499 & $\mathrm{Y}$ & & $\mathrm{X}$ & & & \\
\hline INDOT & SR 218 & 65,176 & $\mathrm{Y}$ & & & & & \\
\hline INDOT & SR 9 & 97,768 & $\mathrm{Y}$ & $\mathrm{X}$ & $\mathrm{X}$ & $\mathrm{X}$ & & \\
\hline INDOT & SR 3 & 72,200 & $\mathrm{Y}$ & & $\mathrm{X}$ & $\mathrm{X}$ & & \\
\hline INDOT & US 20 & 81,355 & $\mathrm{Y}$ & $\mathrm{X}$ & $\mathrm{x}$ & & & Metal angle debonded \\
\hline INDOT & SR 44 & 73,341 & $\mathrm{Y}$ & & $\mathrm{X}$ & $\mathrm{X}$ & & \\
\hline INDOT & SR 45 & 67,851 & & & & & & \\
\hline INDOT & SR 101 & 50,196 & $\mathrm{Y}$ & & $\bar{X}$ & $\mathrm{X}$ & & \\
\hline INDOT & SR 135 & 49,929 & & & & & & \\
\hline INDOT & SR 356 & 68,527 & & & & & & \\
\hline INDOT & US 52 & 88,100 & $\mathrm{Y}$ & & $\mathrm{x}$ & & & \\
\hline INDOT & SR 67 & 197,390 & & & & & & \\
\hline INDOT & SR 427 & 120,947 & & & & & & \\
\hline INDOT & SR 111 & 45,859 & & & & & & \\
\hline INDOT & SR 252 & 210,026 & & & & & & \\
\hline Evansville & FULTON AVE & 65,290 & & & & & & \\
\hline South Bend & KEMBLE AVE & 50,800 & $\mathrm{Y}$ & $\mathrm{X}$ & $\mathrm{X}$ & & & \\
\hline INDOT & SR 5 & 99,042 & $\mathrm{Y}$ & & $\mathrm{X}$ & & & \\
\hline INDOT & SR 26 & 99,815 & & & & & & \\
\hline INDOT & SR 63 & 115,210 & & & & & & \\
\hline INDOT & US 421 & 118,388 & $\mathrm{Y}$ & $\mathrm{X}$ & $\mathrm{X}$ & & $\begin{array}{l}x \\
\end{array}$ & \\
\hline INDOT & US 41 & 106,000 & & & & & & \\
\hline INDOT & US 41 & 114,904 & & & & & & \\
\hline
\end{tabular}

Table A1 Continued: Precast Concrete Railroad Crossings in the State of Indiana 


\begin{tabular}{|c|c|c|c|c|c|c|c|c|}
\hline Agency & Road Name & Surface $\$$ & 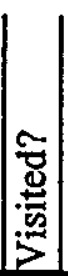 & 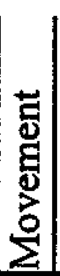 & 密 & & 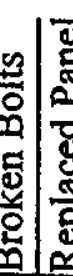 & Comments \\
\hline INDOT & US 50 & 426,454 & & & & & & \\
\hline Anderson & NICHOL AVE & 100,500 & $\mathrm{Y}$ & & & & & Replaced with rubber \\
\hline Evansville & MAIN ST & 66,200 & & & & & & \\
\hline Evansville & WASHINGTON & 96,400 & & & & & & \\
\hline Kokomo & PLATE ST & 308,157 & $\mathrm{Y}$ & & & & & Not Found \\
\hline INDOT & SR 327 & 182,488 & & & & & & \\
\hline INDOT & SR 5 & 64,037 & $\mathrm{Y}$ & & & & & \\
\hline INDOT & SR 827 & 154,632 & $\mathrm{Y}$ & & $\mathrm{X}$ & $\mathrm{x} / 2$ & $\mathrm{X}$ & \\
\hline INDOT & SR 9 & 39,473 & $\mathrm{Y}$ & & $\mathrm{X}$ & $\mathrm{X}$ & & \\
\hline INDOT & SR 135 & 45,160 & & & & & & \\
\hline Bartholemew & CR 450S & 62,883 & & & & & & \\
\hline Tipton & DIVISION RD & & $\mathrm{Y}$ & & & & & Not Found \\
\hline Noblesville & $8 \mathrm{TH} \mathrm{ST}$ & $1,366,859$ & $\mathrm{Y}$ & & & $\bar{X}$ & & 3 blocks long \\
\hline Dekalb & CR 141(CR31) & 59,651 & & & & & & \\
\hline Kokomo & NMAIN ST & 156,113 & $\mathrm{Y}$ & & $\mathrm{X}$ & $\bar{X}$ & & Major surface scaling \\
\hline St. Joseph & WALNUT RD & 126,000 & $\mathrm{Y}$ & & & $\mathrm{X}$ & & \\
\hline INDOT & SR 26 & 54,200 & & & & & & \\
\hline INDOT & SR 111 & 158,561 & & & & & & \\
\hline INDOT & US 41 & 116,352 & $\mathrm{Y}$ & $\mathrm{X}$ & & $\mathrm{X}$ & $\underline{X}$ & \\
\hline INDOT & SR 62 & 45,100 & & & & & & \\
\hline INDOT & SR 71 & 170,000 & & & & & & \\
\hline INDOT & SR 1 & 118,070 & $\mathrm{Y}$ & & & & $\mathrm{X}$ & Bolt head sheared off \\
\hline INDOT & SR 45 & 79,008 & & & & & & \\
\hline INDOT & SR 526 & 98,380 & & & & & & \\
\hline INDOT & US 12 & 81,437 & & & & & & \\
\hline INDOT & US 12 & $71,7.45$ & & & & & & \\
\hline Gary & BUCHANAN ST & 106,901 & & & & & & \\
\hline Pike & ILLINOIS ST & 114,763 & & & & & & \\
\hline Lapel & MAIN ST & 57,850 & $\mathrm{Y}$ & & & & & Welded lay in panels \\
\hline INDOT & SR 930 & 32,770 & $\mathrm{Y}$ & & & & & Platform Type \\
\hline Terre Haute & FRUITRIDGE & 500,000 & & & & & & \\
\hline
\end{tabular}

Table A1 Continued: Precast Concrete Railroad Crossings in the State of Indiana 


\begin{tabular}{|c|c|c|c|c|c|c|c|c|}
\hline Agency & Road Name & Surface \$ & 密 & ${ }_{\Sigma}^{0}$ & & & 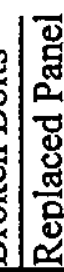 & Comments \\
\hline Martinsville & MORGAN ST & 72,847 & & & & & & \\
\hline INDOT & SR 9 & 133,500 & $\mathrm{Y}$ & & & $\mathrm{X}$ & & \\
\hline INDOT & SR 28 & 89,100 & $Y$ & & & & & Replaced with rubber \\
\hline INDOT & SR 3 & 198,040 & & & & & & \\
\hline Marion & WEST ST & 148,000 & $Y$ & & $\mathrm{X}$ & $\mathrm{X}$ & & \\
\hline East Chicago & MICHIGAN AVE & 356,400 & & & & & & \\
\hline East Chicago & MICHIGAN AVE & 99,565 & & & & & & \\
\hline East Chicago & KENNEDY AVE & 90,127 & & & & & & \\
\hline East Chicago & DICKEY RD & 185,000 & & & & & & \\
\hline Fishers & 116TH ST & 242,228 & $\bar{Y}$ & & $\mathrm{X}$ & $\bar{X}$ & & \\
\hline East Chicago & MICHIGAN AVE & 99,500 & & & & & & \\
\hline Evansville & OHIO ST & 84,889 & & & & & & \\
\hline Brownsburg & CR 600E & 143,200 & $\mathrm{Y}$ & & & $\mathrm{X}$ & & \\
\hline Pittsboro & MERIDIAN ST & 61,900 & $\mathrm{Y}$ & $\mathrm{X}$ & $\mathrm{X}$ & & & \\
\hline Clinton & MAIN ST & 62,763 & & & & & & \\
\hline Whiting & $129 \mathrm{TH} \mathrm{ST}$ & 49,900 & & & & & & \\
\hline INDOT & US 30 & 104,000 & $\mathrm{Y}$ & & $\mathrm{X}$ & & & Platform type \\
\hline INDOT & SR 206(CR 61) & 68,593 & & & & & & \\
\hline & GREENE RD & 136,200 & $\mathrm{Y}$ & & & & & Replaced with rubber \\
\hline INDOT & SR 66 & 35,239 & $\mathrm{Y}$ & & $\mathrm{X}$ & & & \\
\hline Jancock & CR 600W & 146,150 & $\mathrm{Y}$ & & & & & \\
\hline Madison & CR 450S & 134,400 & & & & & & \\
\hline
\end{tabular}


APPENDIX B - MINUTES OF MEETINGS 
7-23-98 Meeting in Indianappolis, Governmental Center South

Clint Brookhart, from Oldcastle Plant in Littleton CO.

- Littleton is the newest plant

- Usually makes underground utility structures (for US West)

- Durability Issues:

Production Process:

panels finished upside down

6,000 psi at 28 day strength

0.44 water - cement ratio

plasticizers and 4 - $6 \%$ air entrainment

Loading Conditions:

indeterminant loading conditions

$60^{\mathrm{k}}$ impact loading

section too thin to resist with reinforced concrete design

Design Summary:

flangeway $=$ outer panel

gage $=$ inner panel

wheel load per HS20 (AASHTO)

$f_{\text {cr }}$ from equation, not tests

each strand post tensioned to $33,000 \mathrm{lbs}$

first visible cracks at $779.9 \mathrm{psi}$

visble cracks at 1,223 psi

cracks close when load is removed

strand at center of gravity

hydrozo sealer on top of panel

bumps cast into riding surface - no finish work needed

- Possibilities of replacing crossings in Boswell or Reynolds discussed.

- The representatives at INDOT to start the procedures for purchasing a crossing.

- Star Track to be contacted by Purdue researchers with information about 3M fibers. 
9/18/98 Meeting At Boswell Site

Representatives from INDOT / Purdue / KBS

Kevin Stroo, Trainmaster, Kankakee, Beaverville and Southern Railroad

Frank Litherland:

- 10 " - 12 " concrete bed with about 10 " ballast on top:

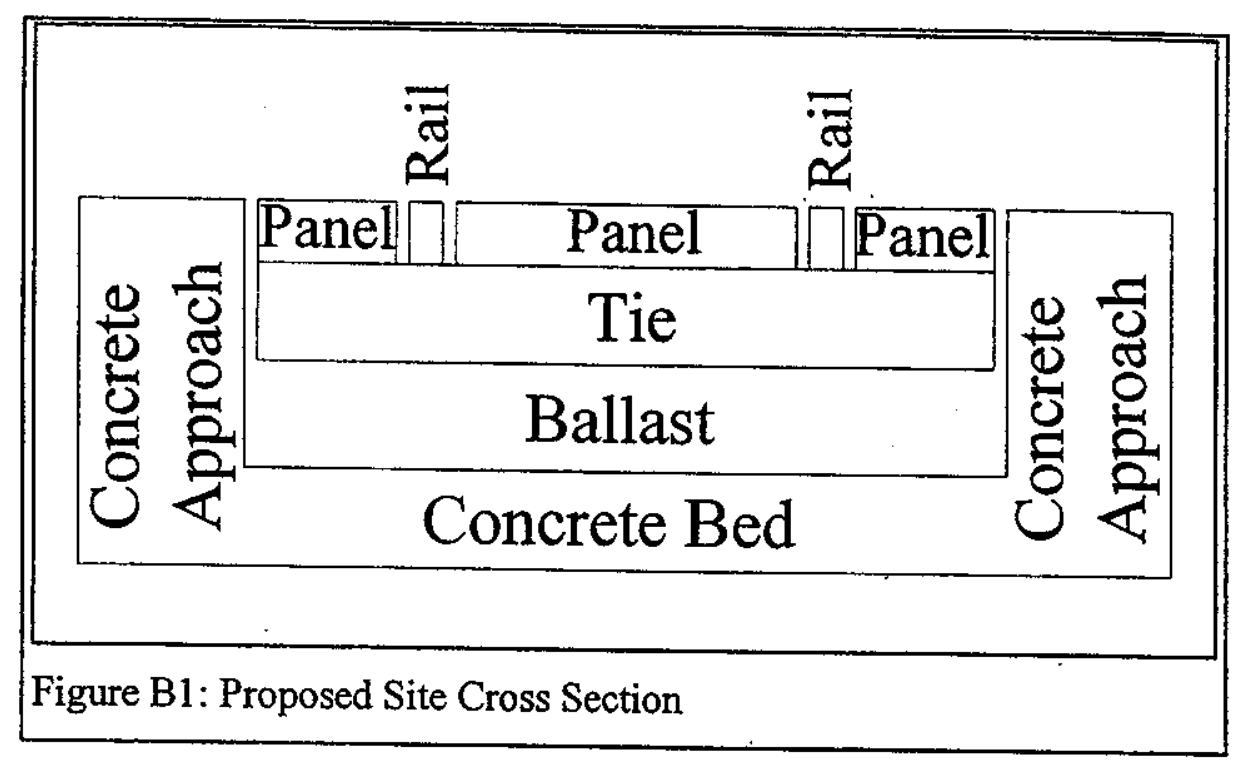

- concrete approaches

- construction can start after October 18 (end of covered bridge days) 


\section{APPENDIX C - BOSWELL SITE PHOTOGRAPHS}




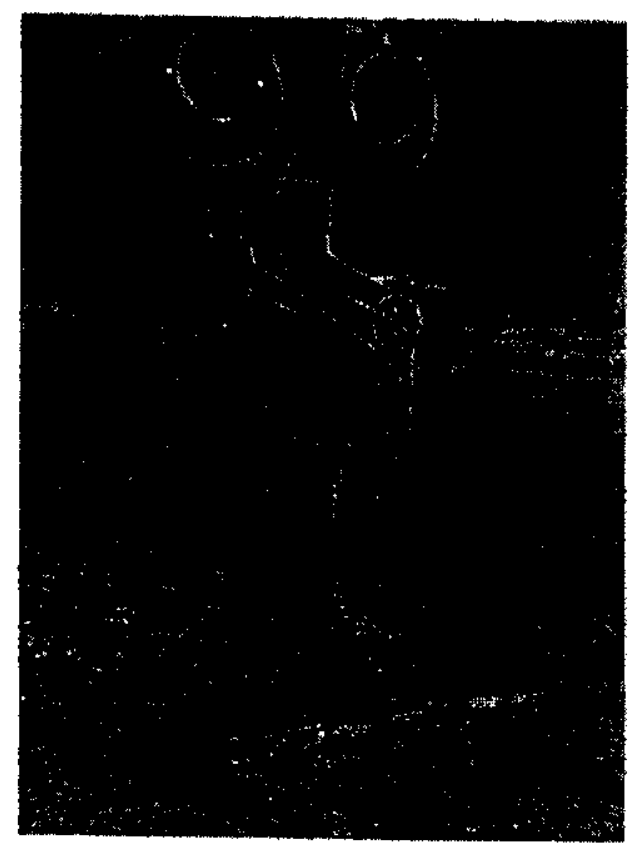

Figure C1: Southbound US 41

signaling gate. High speed truck traffic occasionally damages

equipment if the stopping distance is too short.

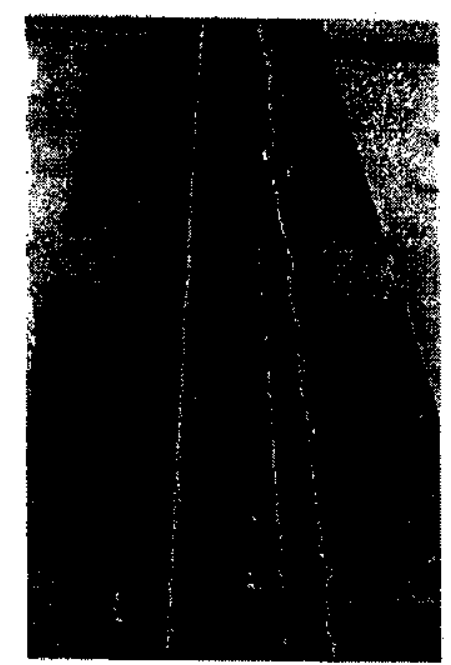

Figure C2: Railroad spikes can be seen pulling out of the timber ties less than two months after tightening. 


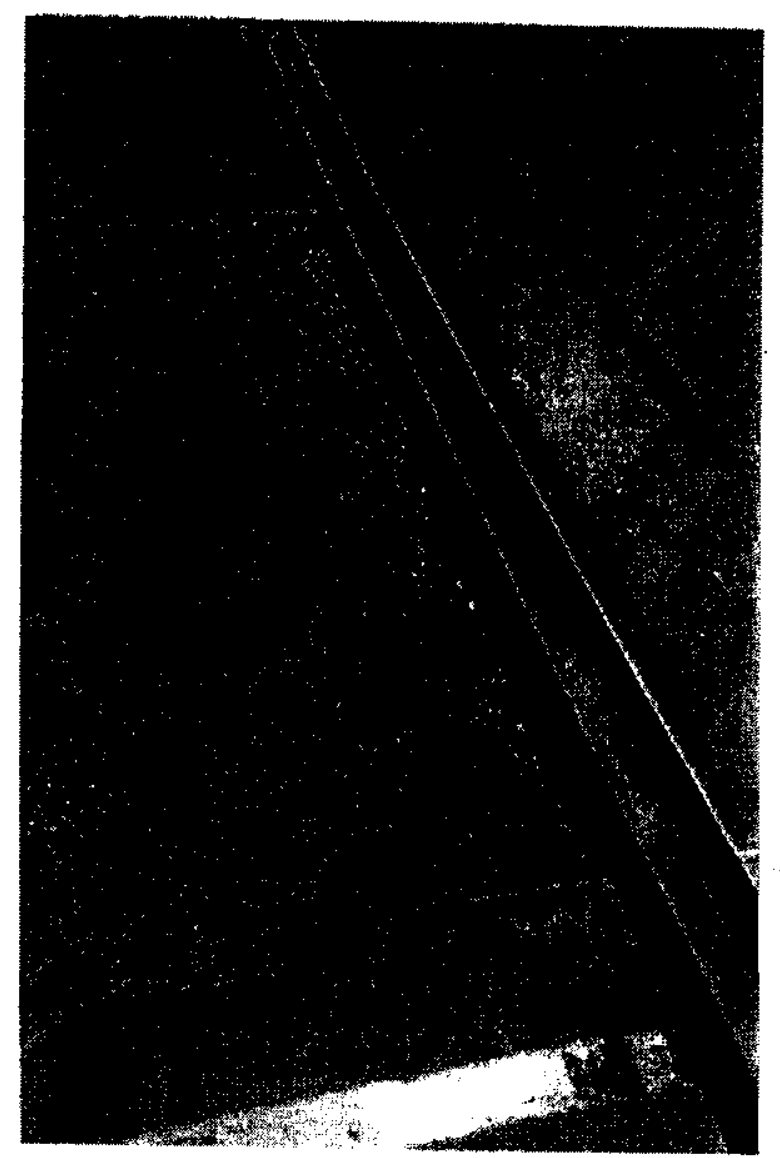

Figure C3: A panel cracked so much it had to be removed. Temporary asphalt fill was placed between the rails. 
APPENDIX D - TEST RESULTS 
Table D1: $0.00 \%$ Fiber Content Test Results

$0.00 \%$ Fiber Content

Modulus of Rupture Data

\begin{tabular}{|c|c|c|} 
Specimen & $\begin{array}{c}\text { MOR } \\
\text { (psi) }\end{array}$ & $\begin{array}{c}\text { Deflection } \\
\text { (in) }\end{array}$ \\
\hline $0-2-1$ & 969 & 0.0122 \\
$0-2-2$ & 964 & 0.0109 \\
$0-2-3$ & 948 & 0.0099 \\
$0-3-1$ & 957 & 0.0108 \\
$0-3-2$ & 968 & 0.0105 \\
$0-3-3$ & 989 & 0.0104 \\
& & \\
$0-4-1$ & 976 & 0.0116 \\
$0-4-2$ & 960 & 0.0105 \\
$0-4-3$ & 1,005 & 0.0106 \\
& & \\
$0-5-1$ & 990 & 0.0123 \\
$0-5-2$ & 950 & 0.0118 \\
$0-5-3$ & 969 & 0.0111 \\
& & \\
$0-6-1$ & 966 & 0.0136 \\
$0-6-2$ & 943 & 0.0107 \\
$0-6-3$ & 995 & 0.0123 \\
& & \\
$0-7-1$ & 938 & 0.0106 \\
$0-7-2$ & 925 & 0.0135 \\
$0-7-3$ & 962 & 0.0104 \\
& & \\
\hline Average & 965 & 0.0113 \\
SD & 21 & 0.0011 \\
& &
\end{tabular}

$0.00 \%$ Fiber Content $\quad 0.00 \%$ Fiber Content Compression Tests Tension Tests

\begin{tabular}{|c|c|c|c|}
\hline Specimen & $\begin{array}{c}f^{\prime} \mathrm{c} \\
(\mathrm{psi}) \\
\end{array}$ & Specimen & $\begin{array}{c}\mathrm{T} \\
\text { (psi) }\end{array}$ \\
\hline $0-20-1$ & 7958 & $0-20-3$ & 588 \\
\hline $0-20-2$ & 8099 & $0-20-4$ & 596 \\
\hline $0-20-6$ & 7922 & $0-20-5$ & 654 \\
\hline \multirow[t]{2}{*}{$0-20-7$} & 8223 & & \\
\hline & & $0-21-3$ & 623 \\
\hline $0-21-2$ & 8117 & $0-21-4$ & 582 \\
\hline $0-21-6$ & 7869 & $0-21-5$ & 631 \\
\hline \multirow[t]{2}{*}{$0-21-7$} & 7728 & & \\
\hline & & $0-22-3$ & 610 \\
\hline $0-22-1$ & 8170 & $0-22-4$ & 622 \\
\hline $0-22-2$ & 8188 & $0-22-5$ & 591 \\
\hline $0-22-6$ & 8170 & & \\
\hline \multirow[t]{2}{*}{$0-22-7$} & 8188 & Average & 611 \\
\hline & 8057 & SD & 24 \\
\hline SI & 163 & & \\
\hline
\end{tabular}


Table D2: $1.00 \%$ Fiber Content Test Results

$1.00 \%$ Fiber Content

Modulus of Rupture Data

\begin{tabular}{|c|c|c|} 
Specimen & $\begin{array}{c}\text { MOR } \\
\text { (psi) }\end{array}$ & $\begin{array}{c}\text { Deflection } \\
\text { (in) }\end{array}$ \\
\hline $1.0-3-1$ & 1,150 & 0.0122 \\
$1.0-3-2$ & 1,070 & 0.0103 \\
$1.0-3-3$ & 1,110 & 0.0225 \\
& & \\
$1.0-4-1$ & 988 & 0.0114 \\
$1.0-4-2$ & 995 & 0.0135 \\
$1.0-4-3$ & 1,010 & 0.0116 \\
& & \\
$1.0-5-1$ & 980 & 0.0106 \\
$1.0-5-2$ & 992 & 0.0088 \\
$1.0-5-3$ & 984 & 0.0118 \\
& & \\
$1.0-6-1$ & 1,030 & 0.0102 \\
$1.0-6-2$ & 1,020 & 0.0101 \\
$1.0-6-3$ & 998 & 0.0107 \\
& & \\
$1.0-7-1$ & 970 & 0.0121 \\
$1.0-7-2$ & 990 & 0.0091 \\
$1.0-7-3$ & 992 & 0.0100 \\
& & \\
\hline Average & 1,019 & 0.0117 \\
SD & 52 & 0.0032 \\
I.
\end{tabular}

$1.00 \%$ Fiber Content $\quad 1.00 \%$ Fiber Content

Compression Tests Tension Tests

\begin{tabular}{|c|c|c|c|}
\hline Specimen & $\begin{array}{c}f c \\
\text { (psi) } \\
\end{array}$ & Specimen & $\begin{array}{c}\mathrm{T} \\
\text { (psi) }\end{array}$ \\
\hline $1.0-20-1$ & 8329 & $1.0-20-3$ & 615 \\
\hline $1.0-20-2$ & 8311 & $1.0-20-4$ & 643 \\
\hline $1.0-20-7$ & 8170 & $1.0-20-5$ & 606 \\
\hline $1.0-21-1$ & 7958 & $1.0-21-3$ & 592 \\
\hline $1.0-21-2$ & 8117 & $1.0-21-4$ & 621 \\
\hline $1.0-21-6$ & 8152 & $1.0-21-5$ & 601 \\
\hline \multirow[t]{2}{*}{$1.0-21-7$} & 7852 & & \\
\hline & & Average & 613 \\
\hline rage & 8127 & SD & 18 \\
\hline
\end{tabular}


Table D3: $1.33 \%$ Fiber Content Test Results

$1.33 \%$ Fiber Content

Modulus of Rupture Data

\begin{tabular}{|c|c|c|c|c|}
\hline Specimen & $\begin{array}{c}\text { MOR } \\
(\mathrm{psi})\end{array}$ & $\begin{array}{l}\text { Deflection } \\
\text { (in) }\end{array}$ & Specimen & $\begin{array}{c}f^{\prime} c \\
(p s i)\end{array}$ \\
\hline $1.3-3-2$ & 1190 & 0.0142 & $1.3-20-1$ & 8205 \\
\hline \multirow{2}{*}{$1.3-3-3$} & 1040 & 0.0180 & $1.3-20-2$ & 8329 \\
\hline & & & $1.3-20-6$ & 8294 \\
\hline $1.3-4-1$ & 1050 & 0.0127 & $1.3-20-7$ & 8329 \\
\hline $1.3-4-2$ & 1080 & 0.0129 & & \\
\hline \multirow[t]{2}{*}{$1.3-4-3$} & 988 & 0.0165 & $1.3-21-2$ & 8011 \\
\hline & & & $1.3-21-6$ & 8064 \\
\hline $1.3-5-1$ & 1060 & 0.0140 & $1.3-21-7$ & 7958 \\
\hline \multirow[t]{2}{*}{$1.3-5-2$} & 988 & 0.0203 & & \\
\hline & & & Average & 8170 \\
\hline $1.3-6-1$ & 1050 & 0.0126 & SD & 158 \\
\hline $1.3-6-2$ & 1090 & 0.0150 & & \\
\hline $1.3-6-3$ & 1100 & 0.0132 & & \\
\hline $1.3-7-1$ & 1030 & 0.0148 & & \\
\hline $1.3-7-2$ & 1040 & 0.0145 & & \\
\hline $1.3-7-3$ & 995 & 0.0180 & & \\
\hline $1.3-8-1$ & 1070 & 0.0157 & & \\
\hline $1.3-8-2$ & 1030 & 0.0127 & & \\
\hline $1.3-8-3$ & 1110 & 0.0176 & & \\
\hline $1.3-9-1$ & 990 & 0.0137 & & \\
\hline $1.3-9-2$ & 1050 & 0.0147 & & \\
\hline $1.3-9-3$ & 1080 & 0.0130 & & \\
\hline Average & 1054 & 0.0150 & & \\
\hline SD & 50 & 0.0022 & & \\
\hline
\end{tabular}

$1.33 \%$ Fiber Content $\quad 1.33 \%$ Fiber Content Compression Tests Tension Tests

\begin{tabular}{|c|c|}
\hline Specimen & $\begin{array}{c}\mathrm{T} \\
(\mathrm{psi})\end{array}$ \\
\hline $1.3-20-3$ & 671 \\
\hline$|1.3-20-4|$ & 604 \\
\hline $1.3-20-5$ & 614 \\
\hline $1.3-21-3$ & 674 \\
\hline $1.3-21-4$ & 657 \\
\hline $1.3-21-5$ & 627 \\
\hline Average & 641 \\
\hline SD & 30 \\
\hline
\end{tabular}


Table D4: $1.66 \%$ Fiber Content Test Results

$1.66 \%$ Fiber Content

Modulus of Rupture Data

\begin{tabular}{|c|c|c|} 
Specimen & $\begin{array}{c}\text { MOR } \\
\text { (psi) }\end{array}$ & $\begin{array}{c}\text { Deflection } \\
\text { (in) }\end{array}$ \\
\hline $1.6-1-2$ & 978 & 0.0114 \\
& & \\
$1.6-3-1$ & 1180 & 0.0244 \\
$1.6-3-2$ & 1170 & 0.0151 \\
$1.6-3-3$ & 1050 & 0.0242 \\
& & \\
$1.6-4-1$ & 1130 & 0.0144 \\
$1.6-4-2$ & 1110 & 0.0148 \\
$1.6-4-3$ & 1140 & 0.0190 \\
& & \\
$1.6-5-1$ & 1070 & 0.0129 \\
$1.6-5-2$ & 1040 & 0.0188 \\
$1.6-5-3$ & 1080 & 0.0168 \\
& & \\
$1.6-6-1$ & 994 & 0.0162 \\
$1.6-6-2$ & 975 & 0.0141 \\
$1.6-6-3$ & 967 & 0.0116 \\
& & \\
$1.6-7-1$ & 1110 & 0.0144 \\
$1.6-7-2$ & 1230 & 0.0142 \\
$1.6-7-3$ & 1090 & 0.0140 \\
& & \\
$1.6-8-1$ & 1130 & 0.0136 \\
$1.6-8-2$ & 1190 & 0.0143 \\
$1.6-8-3$ & 1160 & 0.0139 \\
& & \\
\hline Average & 1094 & 0.0157 \\
SD & 78 & 0.0036 \\
& &
\end{tabular}

$1.66 \%$ Fiber Content $\quad 1.66 \%$ Fiber Content Compression Tests Tension Tests

\begin{tabular}{|c|c|c|c|}
\hline Specimen & $\begin{array}{c}\mathrm{fl}^{\prime} \mathrm{c} \\
\text { (psi) }\end{array}$ & Specimen & $\begin{array}{c}\mathrm{T} \\
\text { (psi) }\end{array}$ \\
\hline $1.6-20-1$ & 8311 & $|1.6-20-3|$ & 676 \\
\hline $1.6-20-2$ & 8241 & $1.6-20-4$ & 671 \\
\hline $1.6-20-6$ & 8594 & $1.6-20-5$ & 671 \\
\hline $1.6-20-7$ & 8311 & & \\
\hline & & $1.6-22-3$ & 657 \\
\hline $1.6-22-1$ & 8364 & $1.6-22-4$ & 630 \\
\hline $1.6-22-2$ & 8258 & $1.6-22-5$ & 622 \\
\hline $1.6-22-6$ & 8258 & & \\
\hline $1.6-22-7$ & 8347 & \multirow{2}{*}{$\begin{array}{r}\text { Average } \\
\text { SD }\end{array}$} & 655 \\
\hline Average & 8336 & & 23 \\
\hline
\end{tabular}


APPENDIX E - MODULUS OF RUPTURE LOAD - DEFLECTION CURVES 


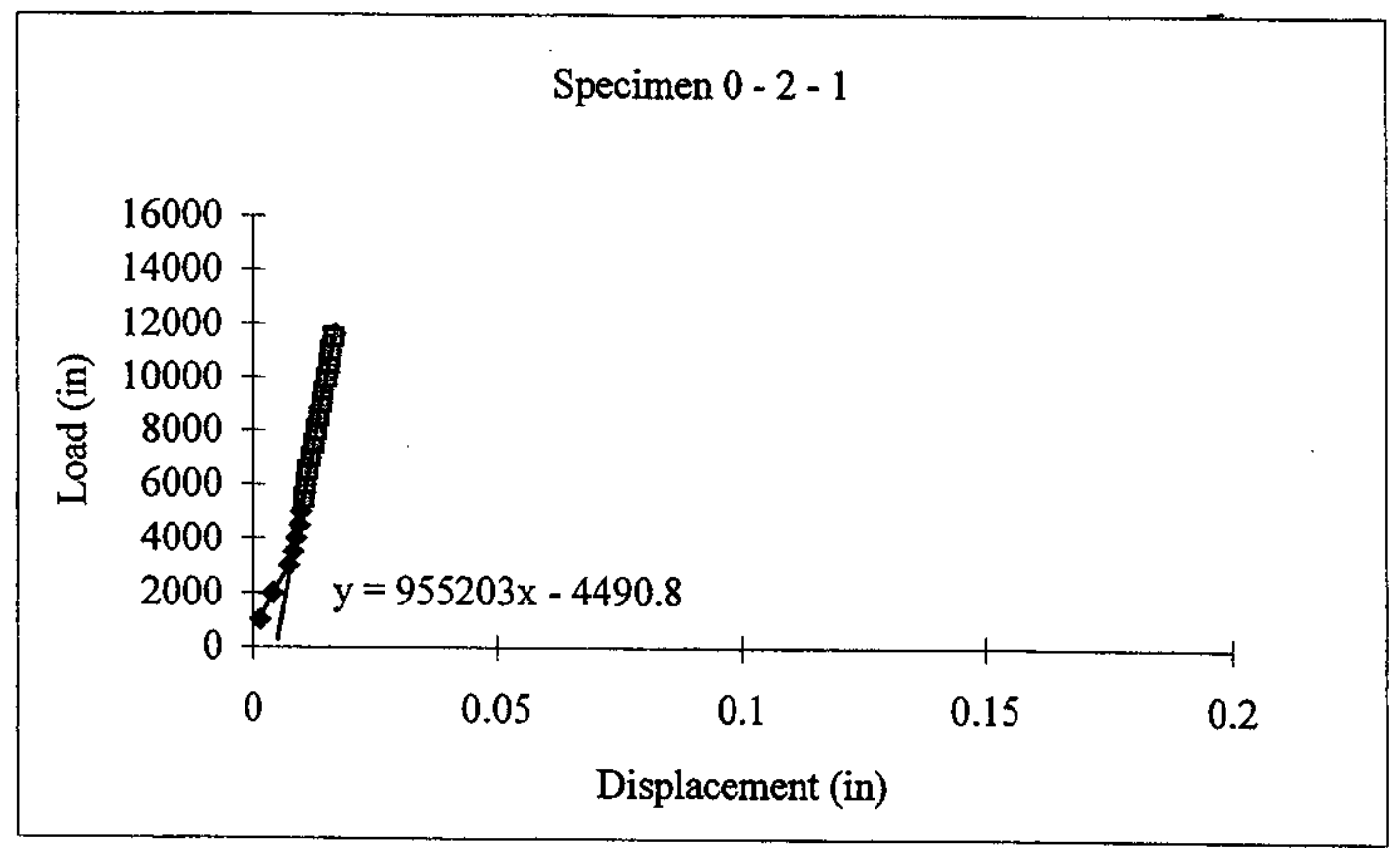

Figure E1: Load Deflection Curve for Specimen 0 - 2 - 1

Table E1: Load Deflection Data for Specimen 0 - 2 - 1

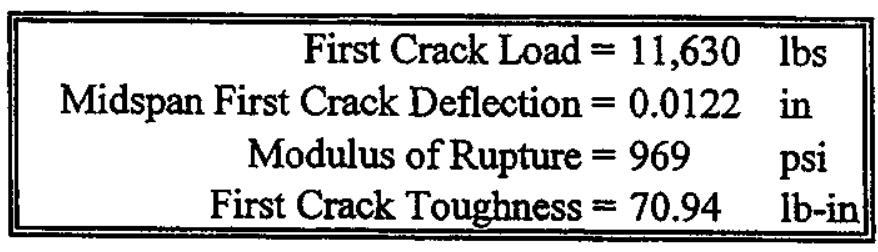

Specimen Type $=$ Molded

Specimen Age $=28 \quad$ days

Specimen Abnormailities $=$ None

Cure $=$ Moist Room

Width $=6 \quad$ in

Depth $=6$ in

Span Length $=18$ in

$\mathrm{O}^{\prime}=0.0047$ in 


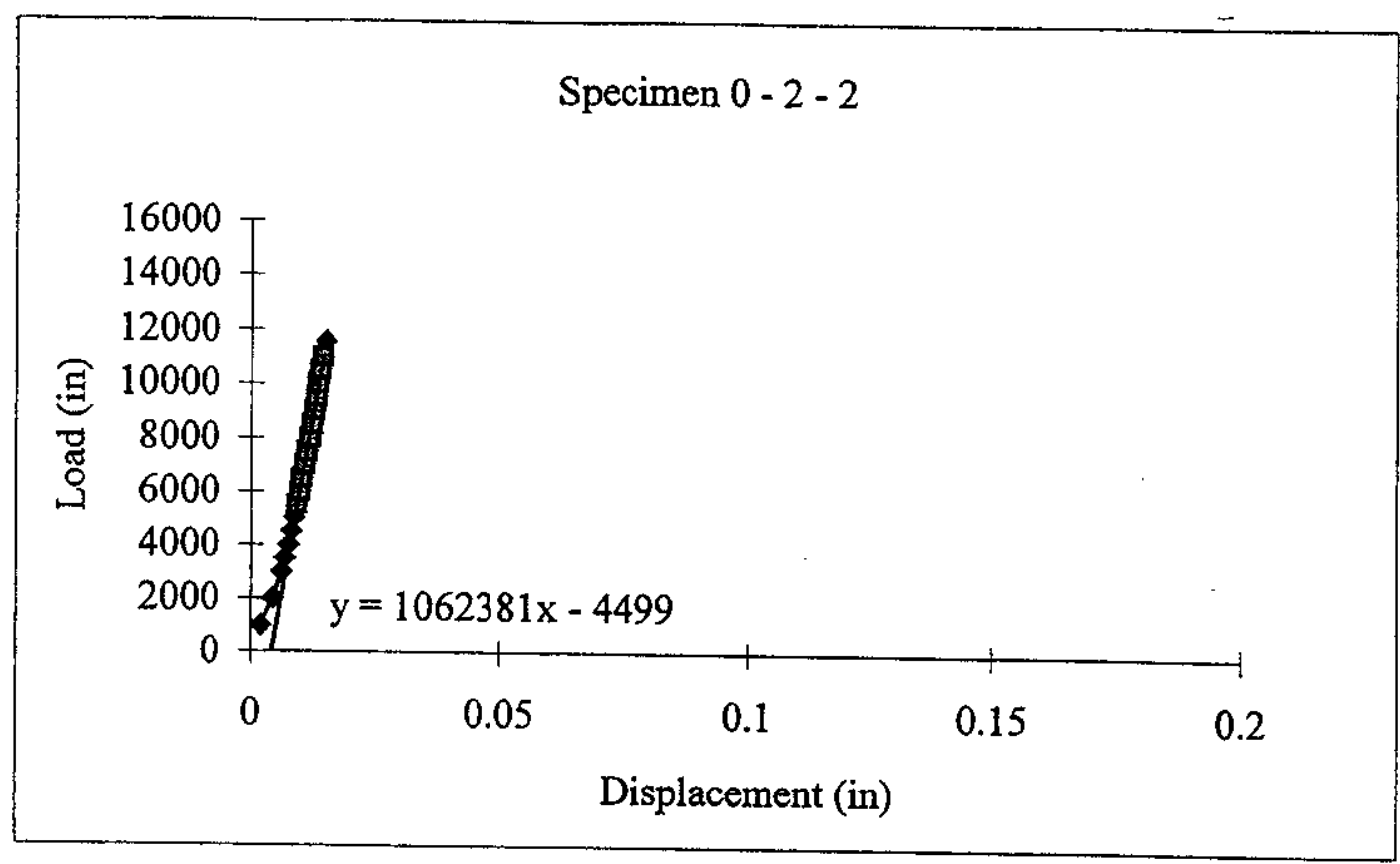

Figure E2: Load Deflection Curve for Specimen 0 - 2-2

Table E2: Load Deflection Data for Specimen 0 - 2 - 2

\begin{tabular}{|c|c|}
\hline $\begin{aligned} \text { First Crack Load } & =11,570 \\
\text { Midspan First Crack Deflection } & =0.0109 \\
\text { Modulus of Rupture } & =964 \\
\text { First Crack Toughness } & =63.06\end{aligned}$ & $\begin{array}{l}\text { bs } \\
\text { n } \\
\text { nsi }\end{array}$ \\
\hline
\end{tabular}

Specimen Type $=$ Molded

Specimen Age $=28$ days

Specimen Abnormailities $=$ None

Cure $=$ Moist Room

Width $=6$ in

Depth $=6$ in .

Span Length $=18$ in

$\mathrm{O}^{\prime}=0.0042 \quad$ in 


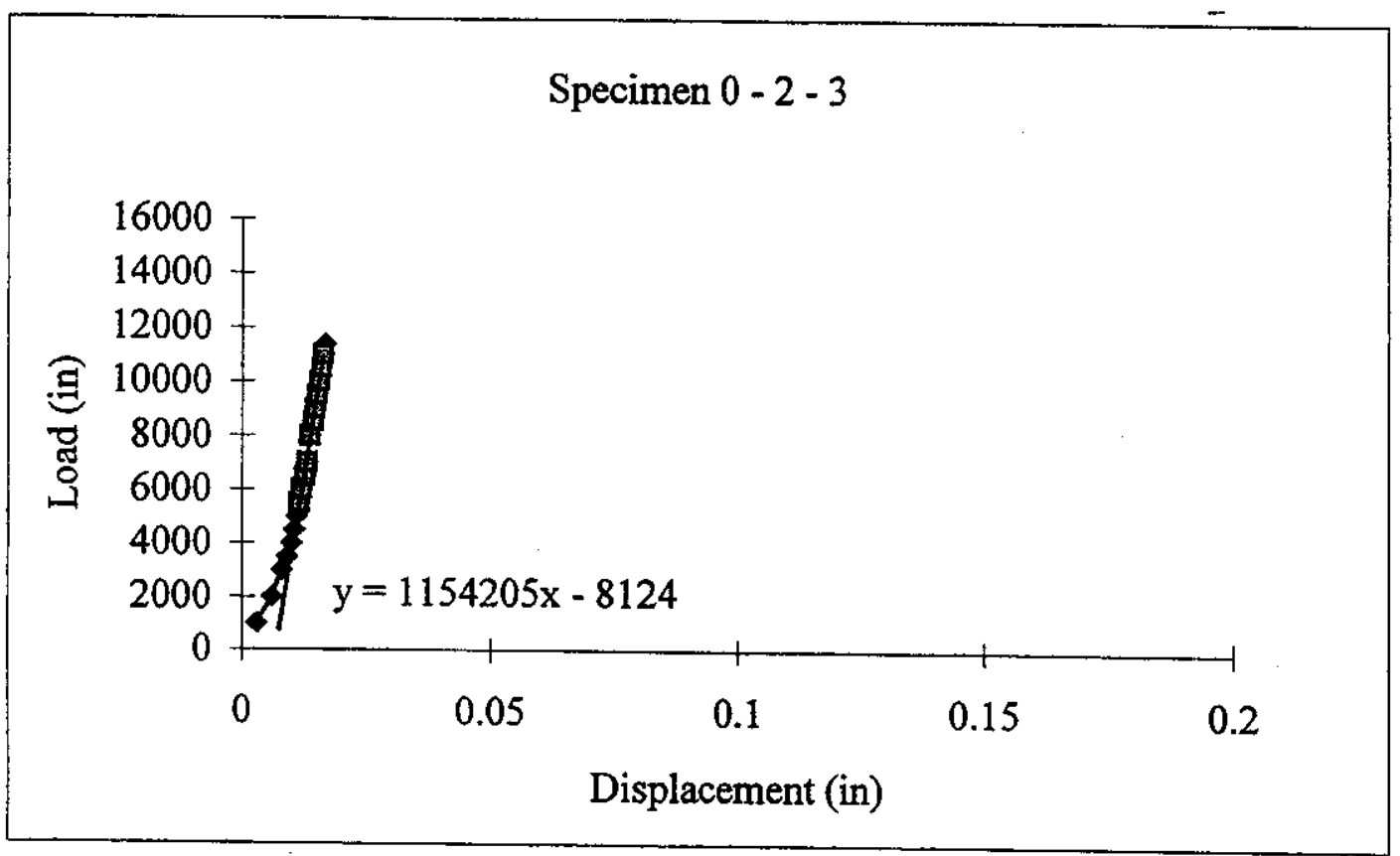

Figure E3: Load Deflection Curve for Specimen 0 - 2 - 3

Table E3: Load Deflection Data for Specimen 0 - 2 - 3

\begin{tabular}{|c|c|}
\hline $\begin{aligned} \text { First Crack Load } & =11,380 \\
\text { Midspan First Crack Deflection } & =0.0099 \\
\text { Modulus of Rupture } & =948 \\
\text { First Crack Toughness } & =56.33\end{aligned}$ & $\begin{array}{l}\text { lbs } \\
\text { in } \\
\text { psi } \\
\text { lb-in }\end{array}$ \\
\hline
\end{tabular}

Specimen Type $=$ Molded

Specimen Age $=28 \quad$ days

Specimen Abnormailities $=$ None

Cure $=$ Moist Room

Width $=6$ in

Depth $=6$ in

Span Length $=18 \quad$ in

$\mathrm{O}^{\prime}=0.007 \quad$ in 


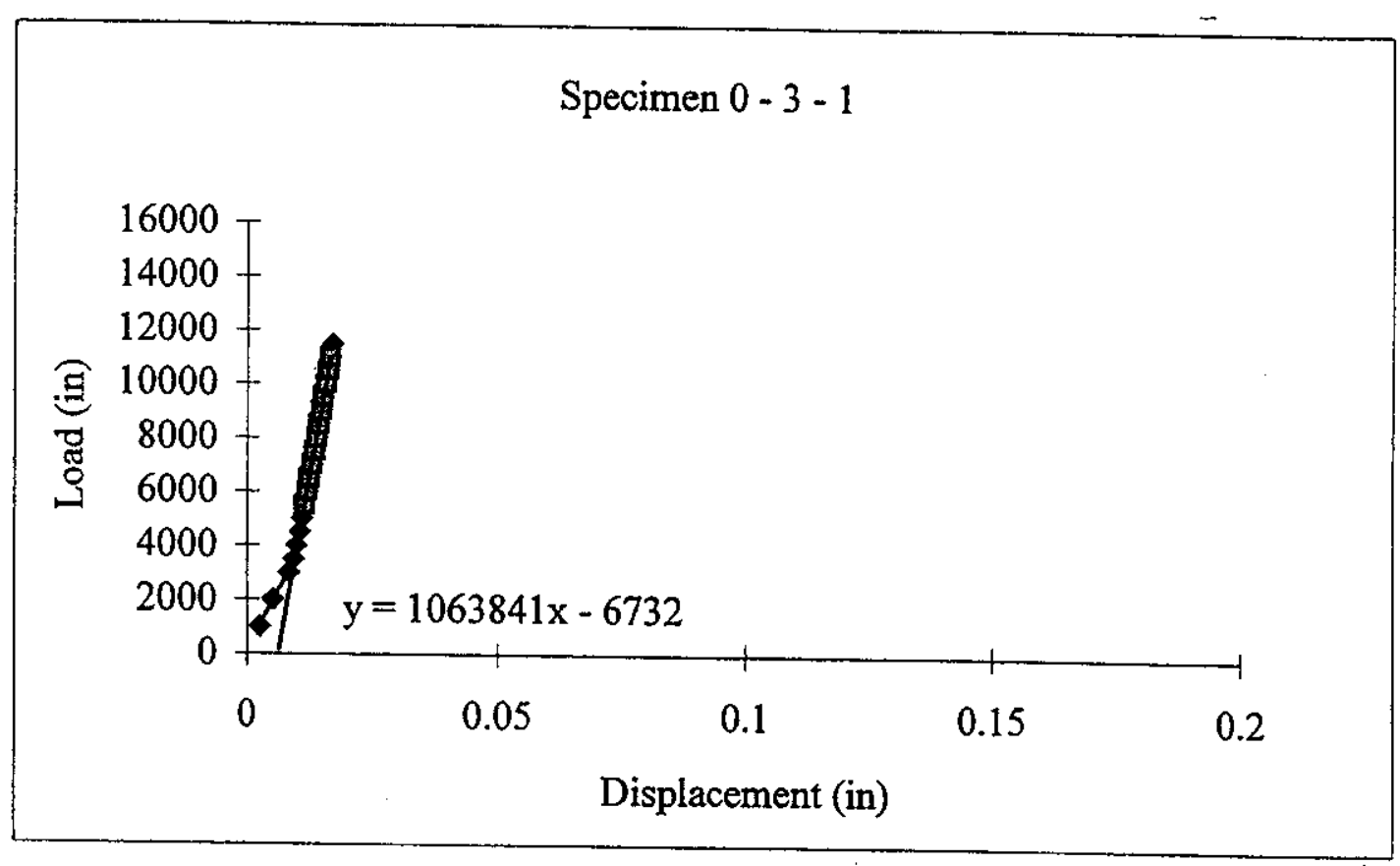

Figure E4: Load Deflection Curve for Specimen 0 - 3 - 1

Table E4: Load Deflection Data for Specimen 0 - 3 - 1

\begin{tabular}{|c|c|}
\hline $\begin{aligned} \text { First Crack Load } & =11,480 \\
\text { Midspan First Crack Deflection } & =0.0108 \\
\text { Modulus of Rupture } & =957 \\
\text { First Crack Toughness } & =61.99\end{aligned}$ & $\begin{array}{l}\text { Ibs } \\
\text { in } \\
\text { psi } \\
\text { lb-in }\end{array}$ \\
\hline
\end{tabular}

Specimen Type $=$ Molded

Specimen Age $=28$ days

Specimen Abnormailities $=$ None

Cure $=$ Moist Room

Width $=6 \quad$ in

Depth $=6$ in

Span Length $=18$ in

$$
\mathrm{O}^{\prime}=0.0063 \quad \text { in }
$$




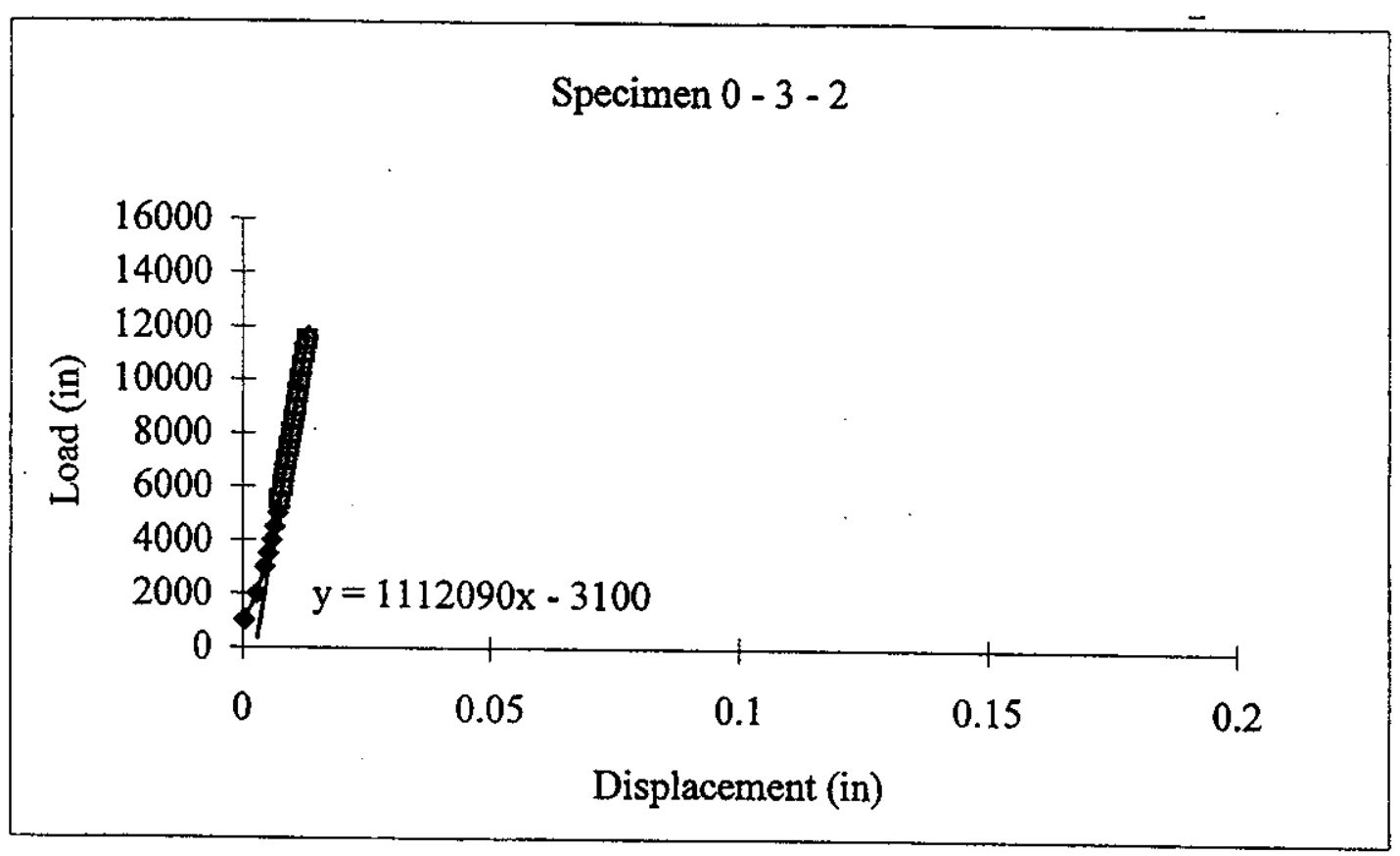

Figure E5: Load Deflection Curve for Specimen 0 - 3 - 2

Table E5: Load Deflection Data for Specimen 0 - 3 - 2

\begin{tabular}{|c|c|}
\hline $\begin{aligned} \text { First Crack Load } & =11,620 \\
\text { Midspan First Crack Deflection } & =0.0105 \\
\text { Modulus of Rupture } & =968 \\
\text { First Crack Toughness } & =61.01\end{aligned}$ & $\begin{array}{l}\text { lbs } \\
\text { in } \\
\text { psi } \\
\text { lb-in }\end{array}$ \\
\hline
\end{tabular}

Specimen Type $=$ Molded

Specimen Age $=28 \quad$ days

Specimen Abnormailities $=$ None

Cure $=$ Moist Room

Width $=6$ in

Depth $=6$ in

Span Length $=18$ in

$$
\mathrm{O}^{\prime}=0.0028 \text { in }
$$




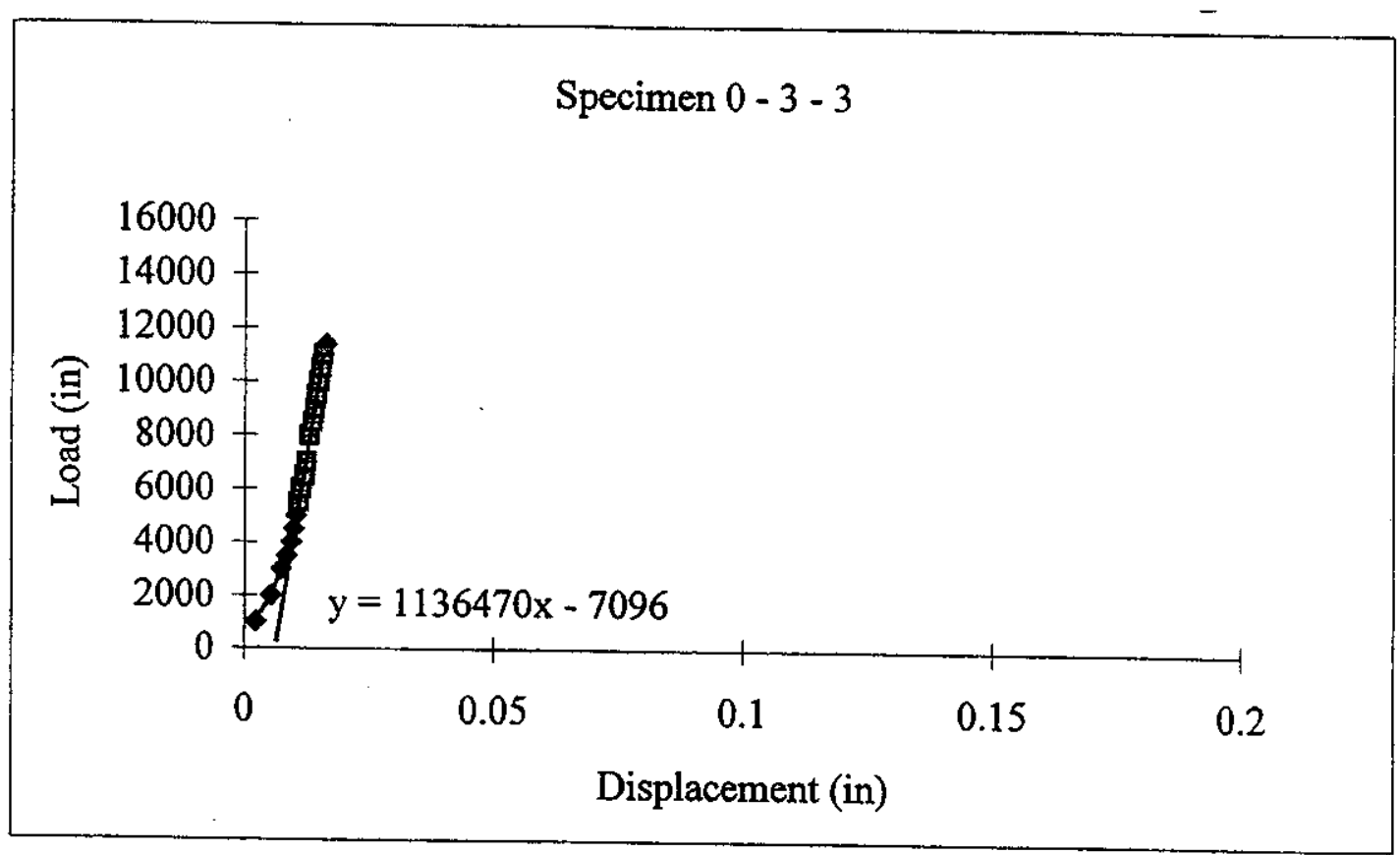

Figure E6: Load Deflection Curve for Specimen 0 - 3 - 3

Table E6: Load Deflection Data for Specimen 0 - 3 - 3

\begin{tabular}{|c|c|}
\hline $\begin{aligned} \text { First Crack Load } & =11,870 \\
\text { Midspan First Crack Deflection } & =0.0104 \\
\text { Modulus of Rupture } & =989 \\
\text { First Crack Toughness } & =61.72\end{aligned}$ & $\begin{array}{l}\text { lbs } \\
\text { in } \\
\text { psi } \\
\text { lb-in }\end{array}$ \\
\hline
\end{tabular}

Specimen Type $=$ Molded

Specimen Age $=28 \quad$ days

Specimen Abnormailities $=$ None

Cure $=$ Moist Room

Width $=6$ in

Depth $=6$ in

Span Length $=18$ in

$\mathrm{O}^{\prime}=0.0062 \quad$ in 


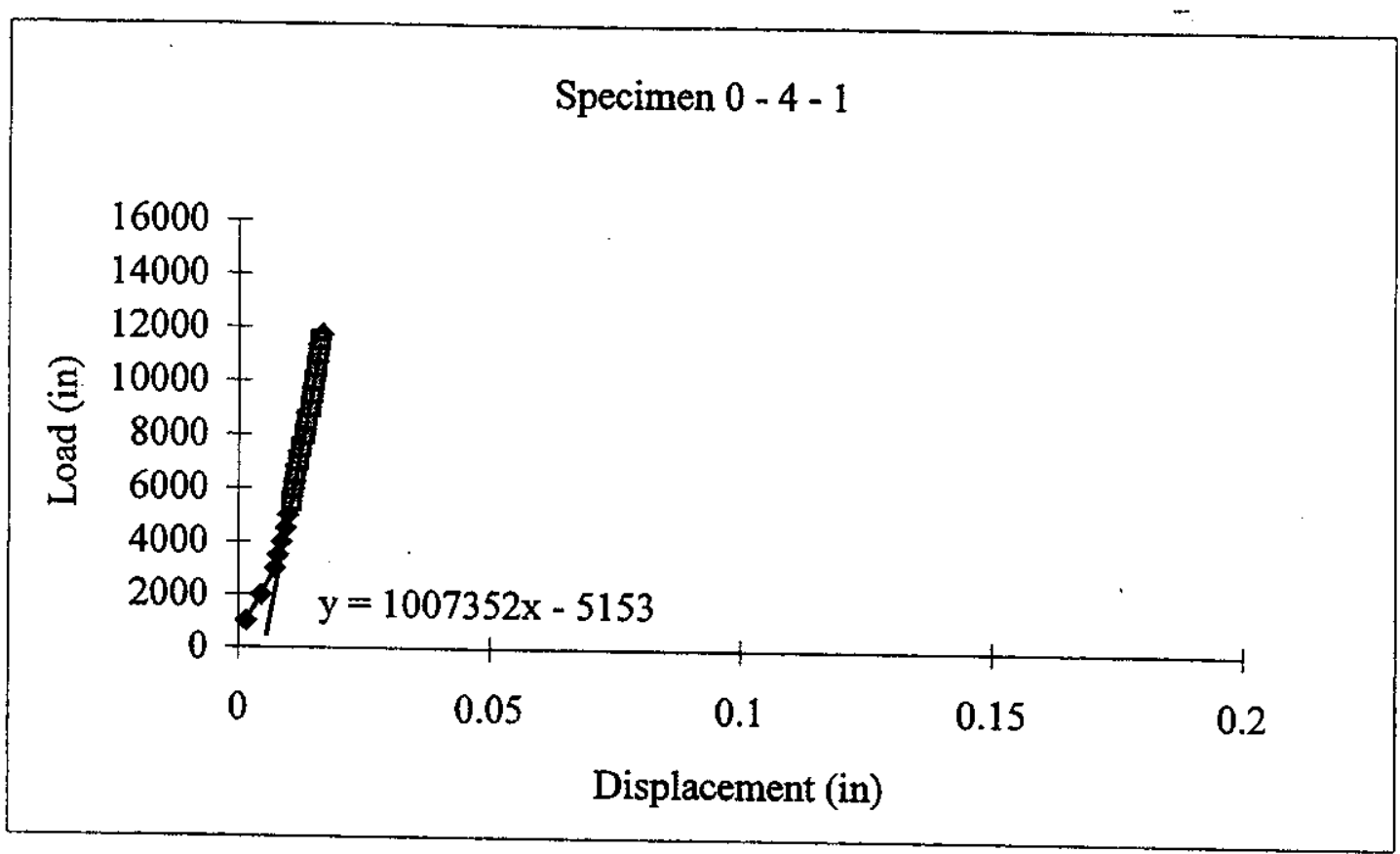

Figure E7: Load Deflection Curve for Specimen 0 - 4 - 1

Table E7: Load Deflection Data for Specimen 0 - 4 - 1

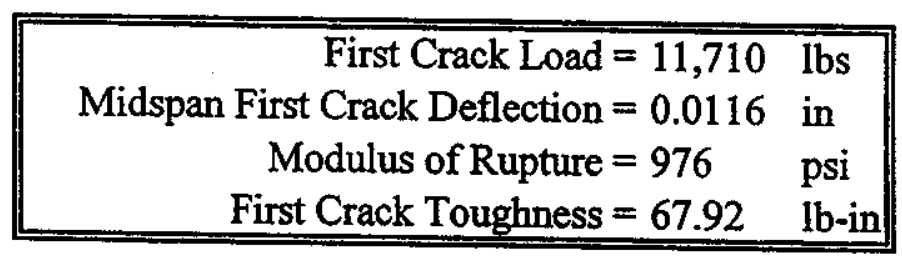

Specimen Type $=$ Molded

Specimen Age $=28 \quad$ days

Specimen Abnormailities $=$ None

Cure $=$ Moist Room

Width $=6$ in

Depth $=6$ in

Span Length $=18$ in

$\mathrm{O}^{\prime}=0.0051 \quad$ in 


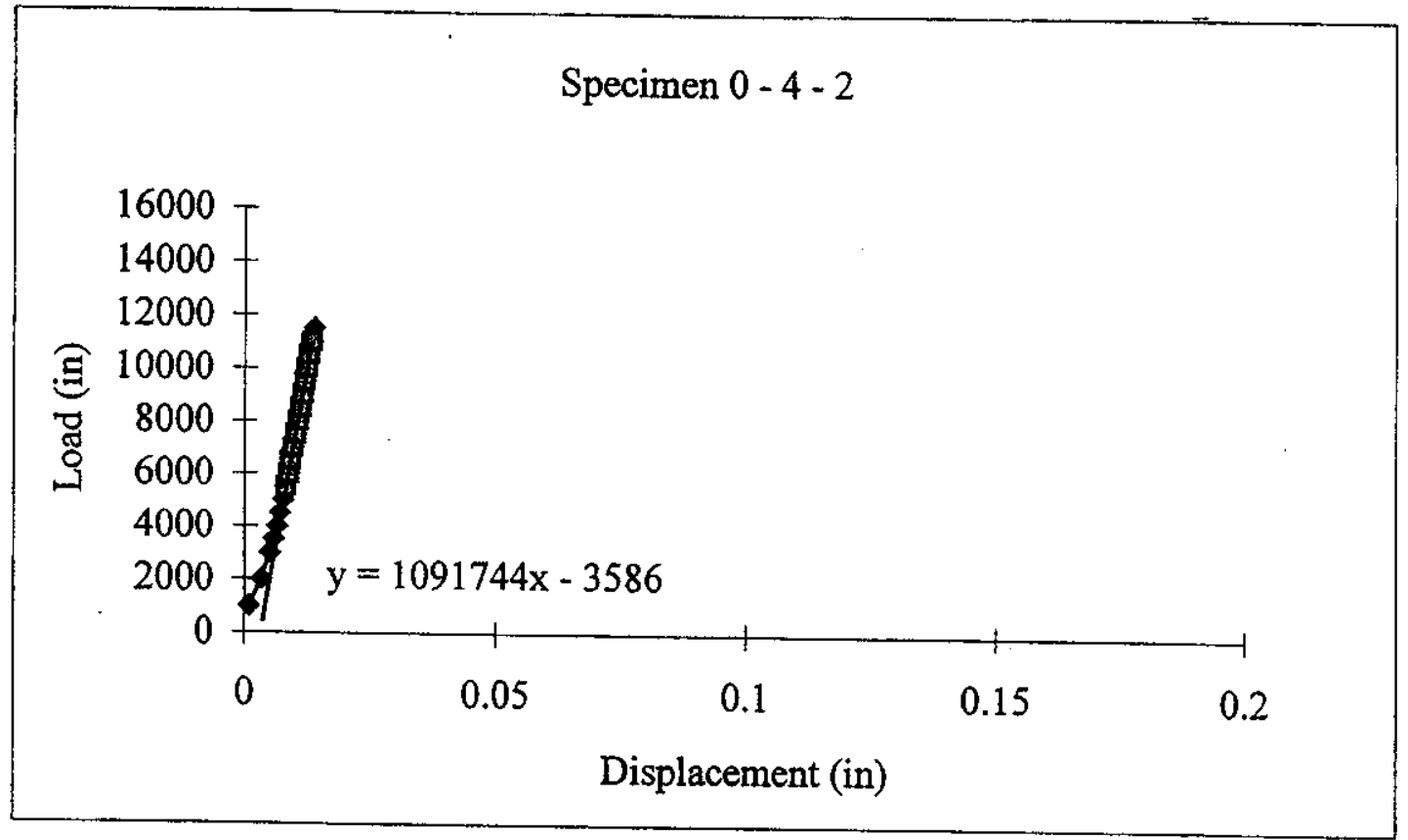

Figure E8: Load Deflection Curve for Specimen 0 - 4 - 2

Table E8: Load Deflection Data for Specimen 0 - 4 - 2

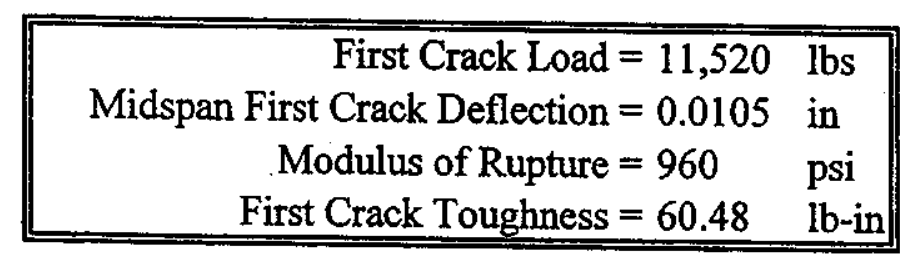

Specimen Type $=$ Molded

Specimen Age $=28 \quad$ days

Specimen Abnormailities $=$ None

Cure $=$ Moist Room

Width $=6$

in

Depth $=6$ in

Span Length $=18$ in

$\mathrm{O}^{\prime}=0.0033$ in 


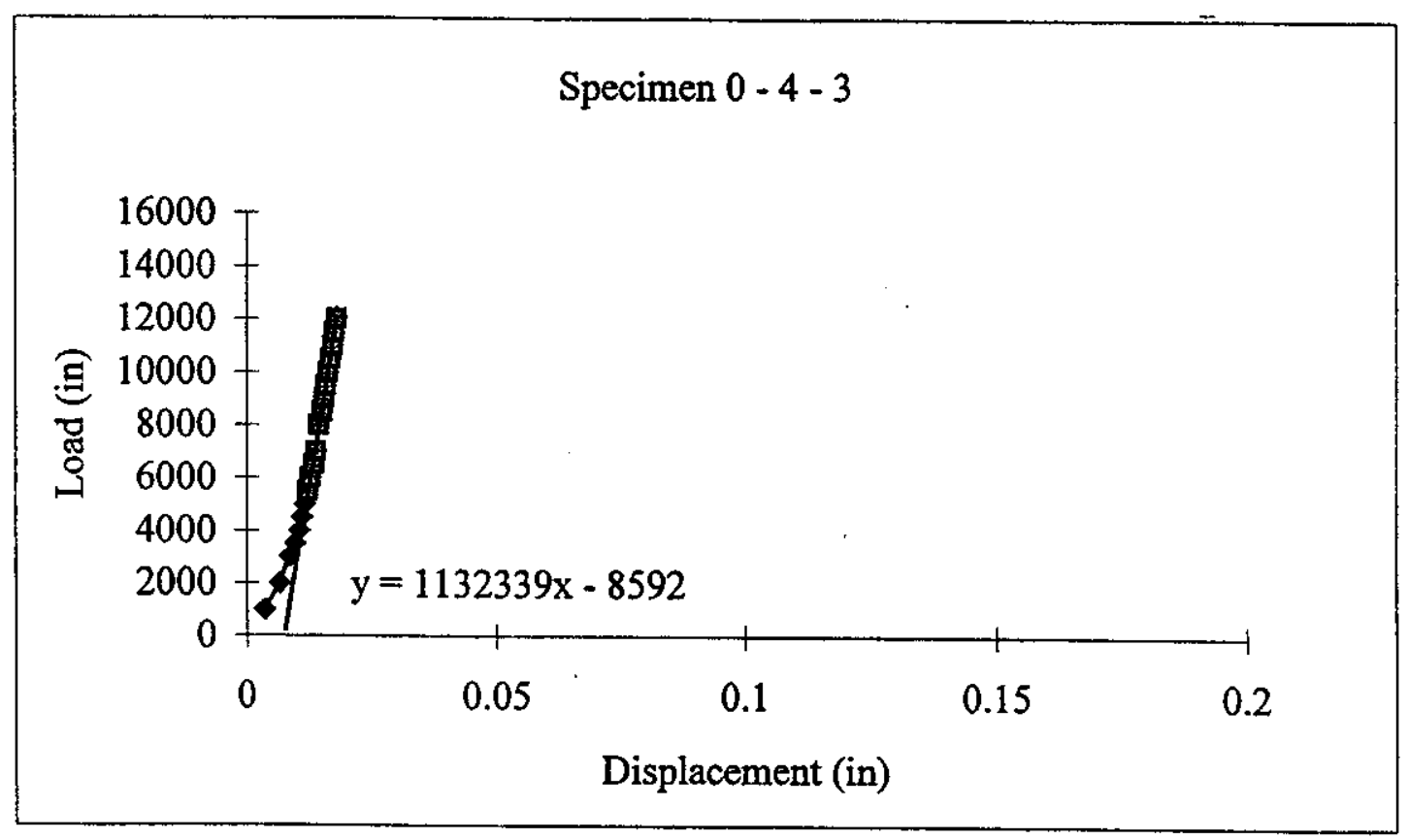

Figure E9: Load Deflection Curve for Specimen 0 - 4 - 3

Table E9: Load Deflection Data for Specimen 0 - 4 - 3

\begin{tabular}{|c|c|}
\hline $\begin{aligned} \text { First Crack Load } & =12,060 \\
\text { Midspan First Crack Deflection } & =0.0106 \\
\text { Modulus of Rupture } & =1005 \\
\text { First Crack Toughness } & =63.92\end{aligned}$ & \begin{tabular}{l|} 
lbs \\
in \\
psi \\
lb-in
\end{tabular} \\
\hline
\end{tabular}

Specimen Type $=$ Molded

Specimen Age $=28 \quad$ days

Specimen Abnormailities $=$ None

Cure $=$ Moist Room

Width $=6$ in

Depth $=6$ in

Span Length $=18$ in

$\mathrm{O}^{\prime}=0.0076$ in 


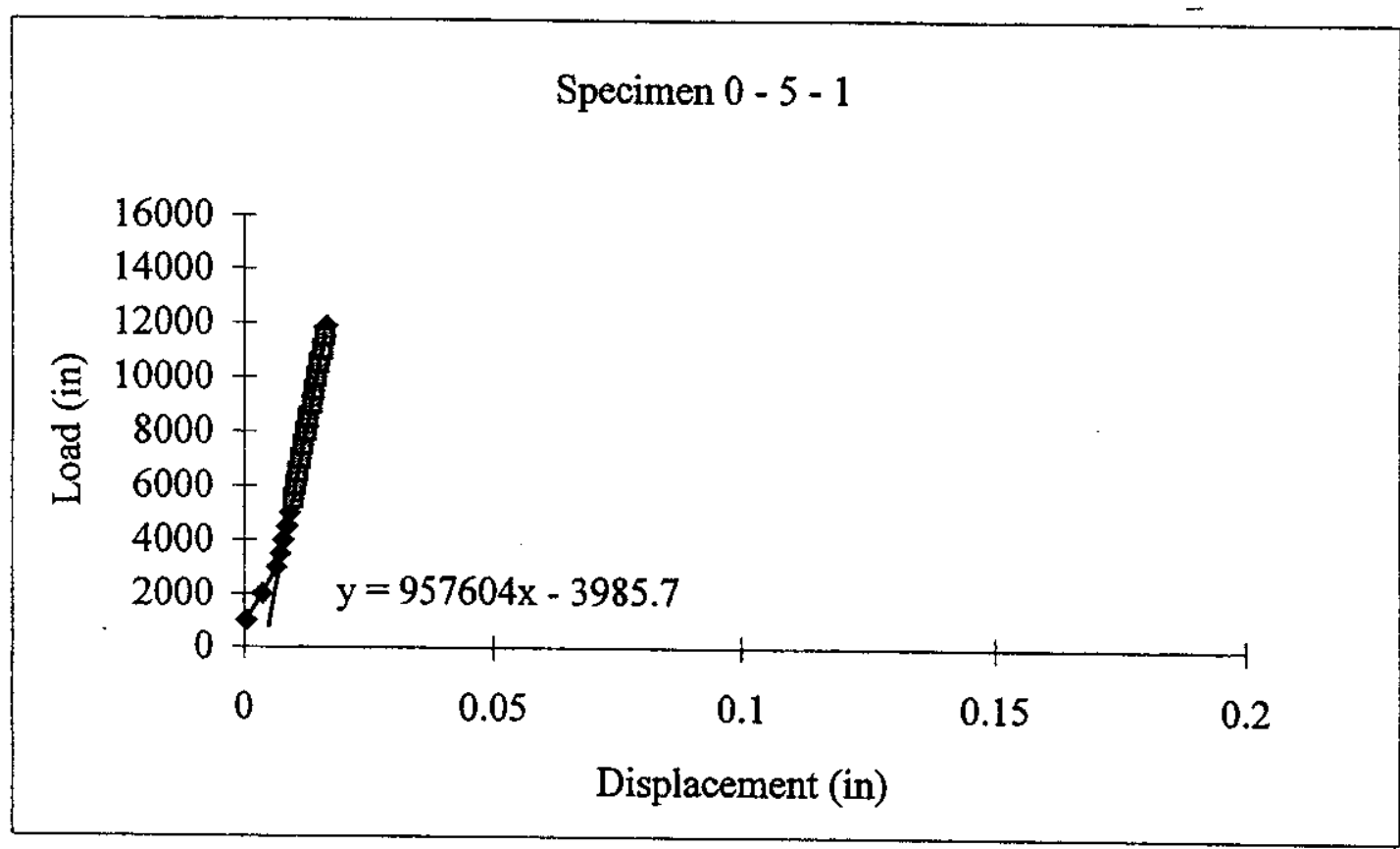

Figure E10: Load Deflection Curve for Specimen 0 - 5 - 1

Table E10: Load Deflection Data for Specimen 0 - 5 - 1

\begin{tabular}{|c|c|}
\hline $\begin{aligned} \text { First Crack Load } & =11,880 \\
\text { Midspan First Crack Deflection } & =0.0123 \\
\text { Modulus of Rupture } & =990 \\
\text { First Crack Toughness } & =73.06\end{aligned}$ & $\begin{array}{l}\text { lbs } \\
\text { in } \\
\text { psi } \\
\text { lb-in }\end{array}$ \\
\hline
\end{tabular}

Specimen Type $=$ Molded

Specimen Age $=28 \quad$ days

Specimen Abnormailities $=$ None

Cure $=$ Moist Room

Width $=6 \quad$ in

Depth $=6$ in

Span Length $=18$ in

$\mathrm{O}^{\prime}=0.0042$ in 


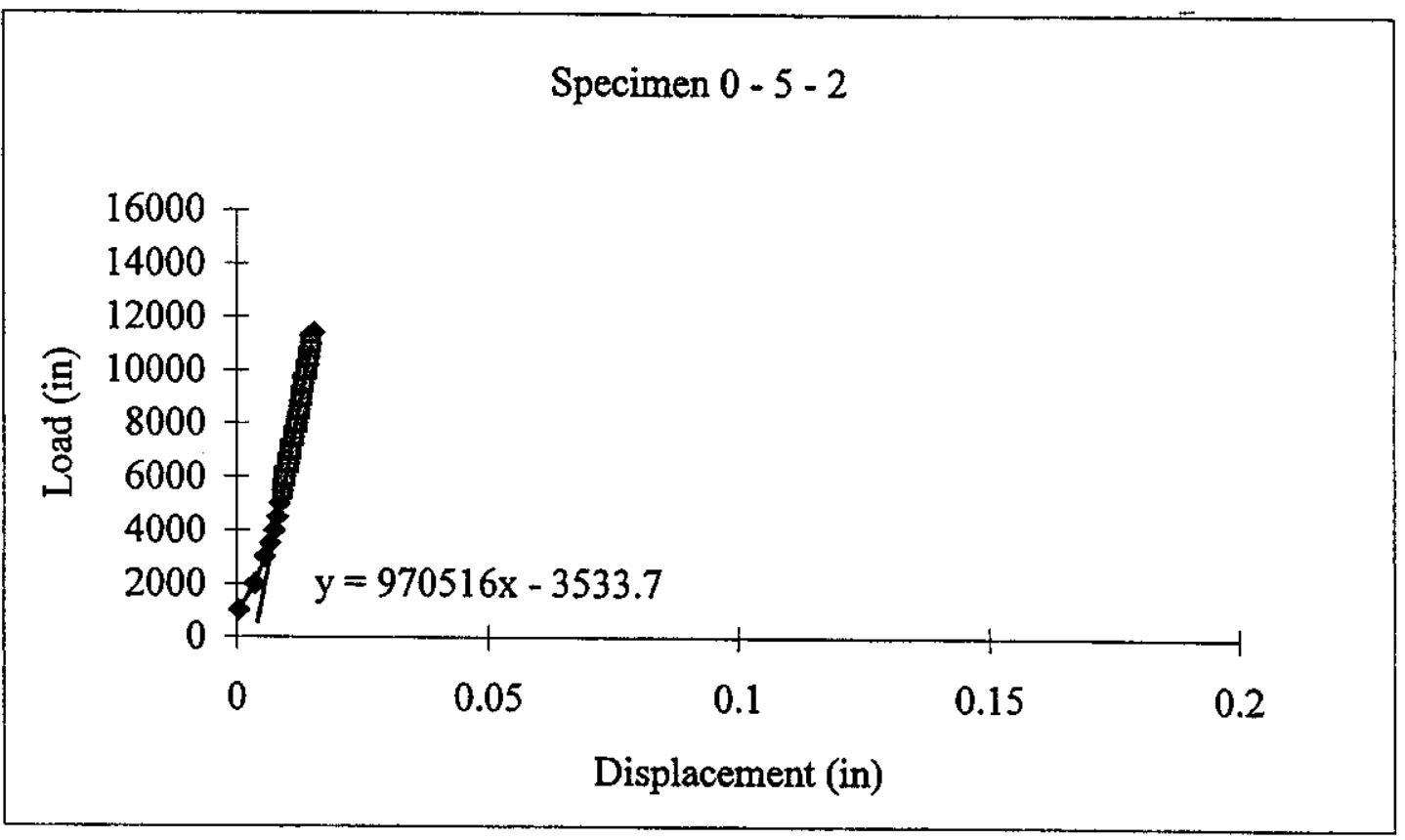

Figure E11: Load Deflection Curve for Specimen 0 - 5 - 2

Table E11: Load Deflection Data for Specimen 0 - 5 - 2

\begin{tabular}{|c|c|}
\hline $\begin{aligned} \text { First Crack Load } & =11,400 \\
\text { Midspan First Crack Deflection } & =0.0118 \\
\text { Modulus of Rupture } & =950 \\
\text { First Crack Toughness } & =67.26\end{aligned}$ & $\begin{array}{l}\text { lbs } \\
\text { in } \\
\text { psi } \\
\text { lb-in }\end{array}$ \\
\hline
\end{tabular}

Specimen Type $=$ Molded

$$
\text { Specimen Age }=28 \text { days }
$$

Specimen Abnormailities $=$ None

Cure $=$ Moist Room

Width $=6 \quad$ in

Depth $=6$ in

Span Length $=18 \quad$ in

$$
\mathrm{O}^{\prime}=0.0036 \text { in }
$$




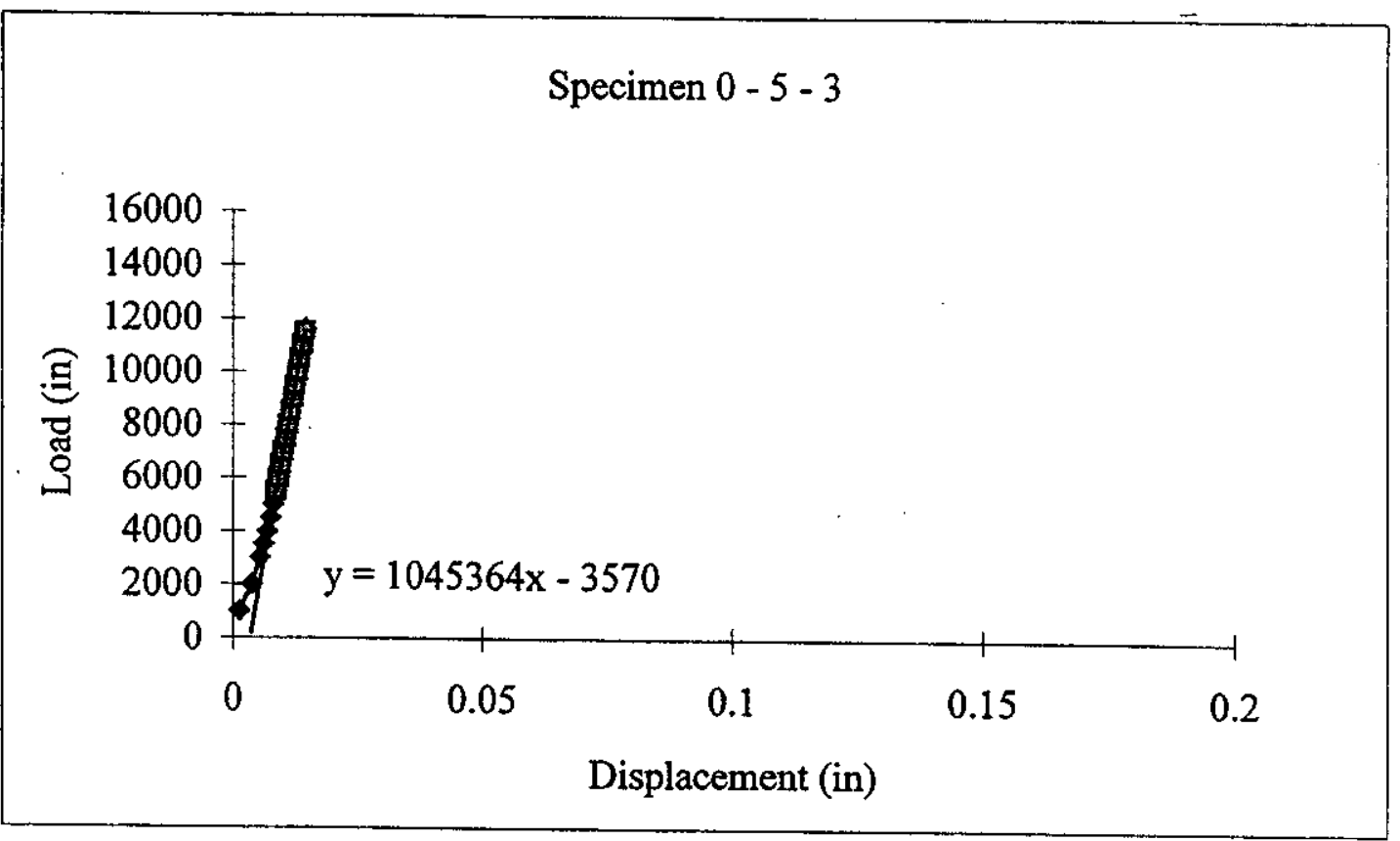

Figure E12: Load Deflection Curve for Specimen 0 - 5 - 3

Table E12: Load Deflection Data for Specimen 0 - 5 - 3

\begin{tabular}{|c|c|}
\hline $\begin{aligned} \text { First Crack Load } & =11,630 \\
\text { Midspan First Crack Deflection } & =0.0111 \\
\text { Modulus of Rupture } & =969 \\
\text { First Crack Toughness } & =64.55\end{aligned}$ & $\begin{array}{l}\text { Ibs } \\
\text { in } \\
\text { psi } \\
\text { lb-in }\end{array}$ \\
\hline
\end{tabular}

Specimen Type $=$ Molded

Specimen Age $=28 \quad$ days

Specimen Abnormailities $=$ None

Cure $=$ Moist Room

Width $=6$ in

Depth $=6$ in

Span Length $=18$ in

$\mathrm{O}^{\prime}=0.0034$ in 


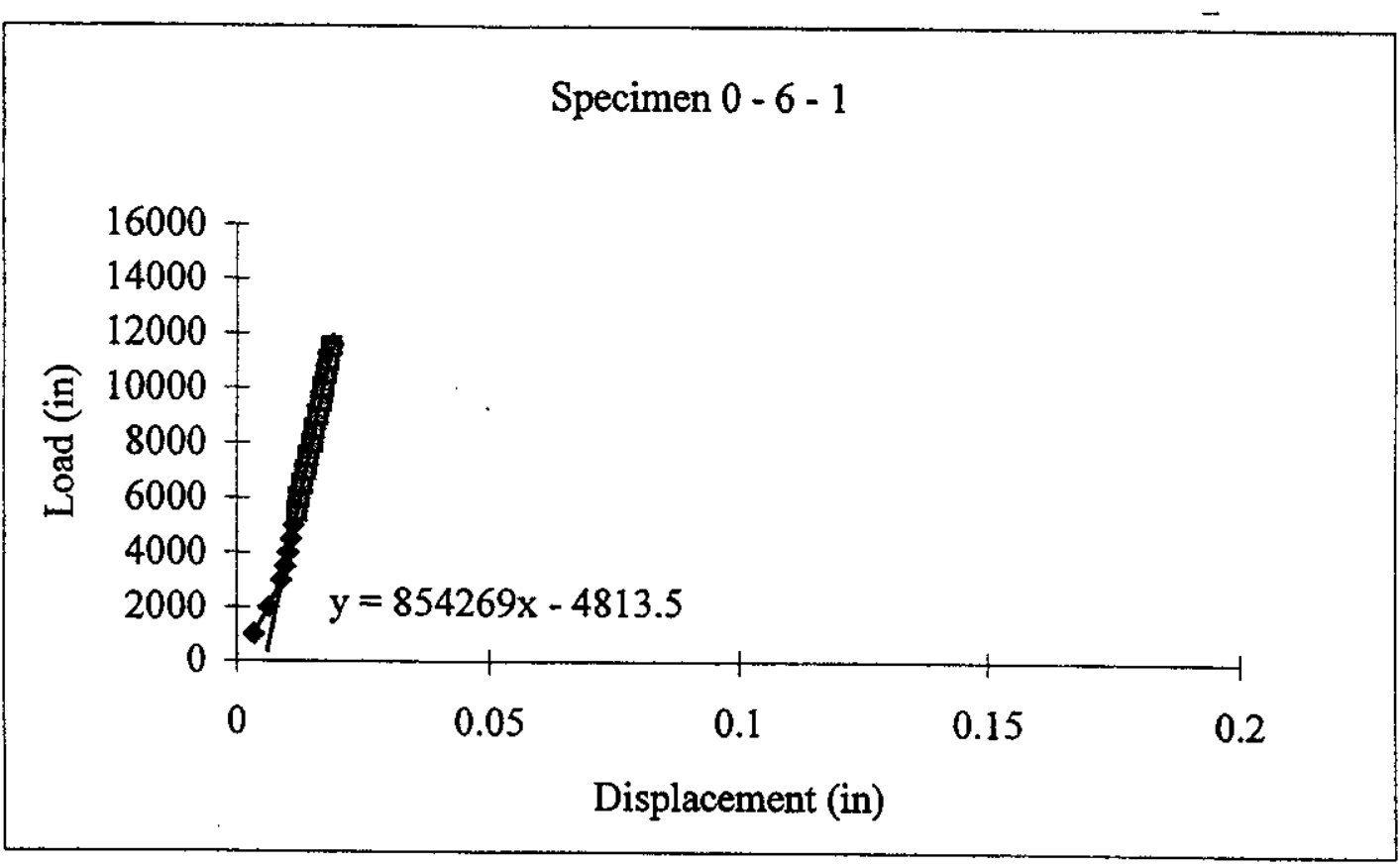

Figure E13: Load Deflection Curve for Specimen 0 - 6 - 1

Table E13: Load Deflection Data for Specimen 0 - 6 - 1

\begin{tabular}{|c|c|}
\hline $\begin{aligned} \text { First Crack Load } & =11,590 \\
\text { Midspan First Crack Deflection } & =0.0136 \\
\text { Modulus of Rupture } & =966 \\
\text { First Crack Toughness } & =78.81\end{aligned}$ & $\begin{array}{l}\text { lbs } \\
\text { in } \\
\text { psi } \\
\text { lb-in }\end{array}$ \\
\hline
\end{tabular}

Specimen Type $=$ Molded

Specimen Age $=28 \quad$ days

Specimen Abnormailities $=$ None

Cure $=$ Moist Room

Width $=6 \quad$ in

Depth $=6$ in

Span Length $=18$ in

$\mathrm{O}^{\prime}=0.0056$ in 


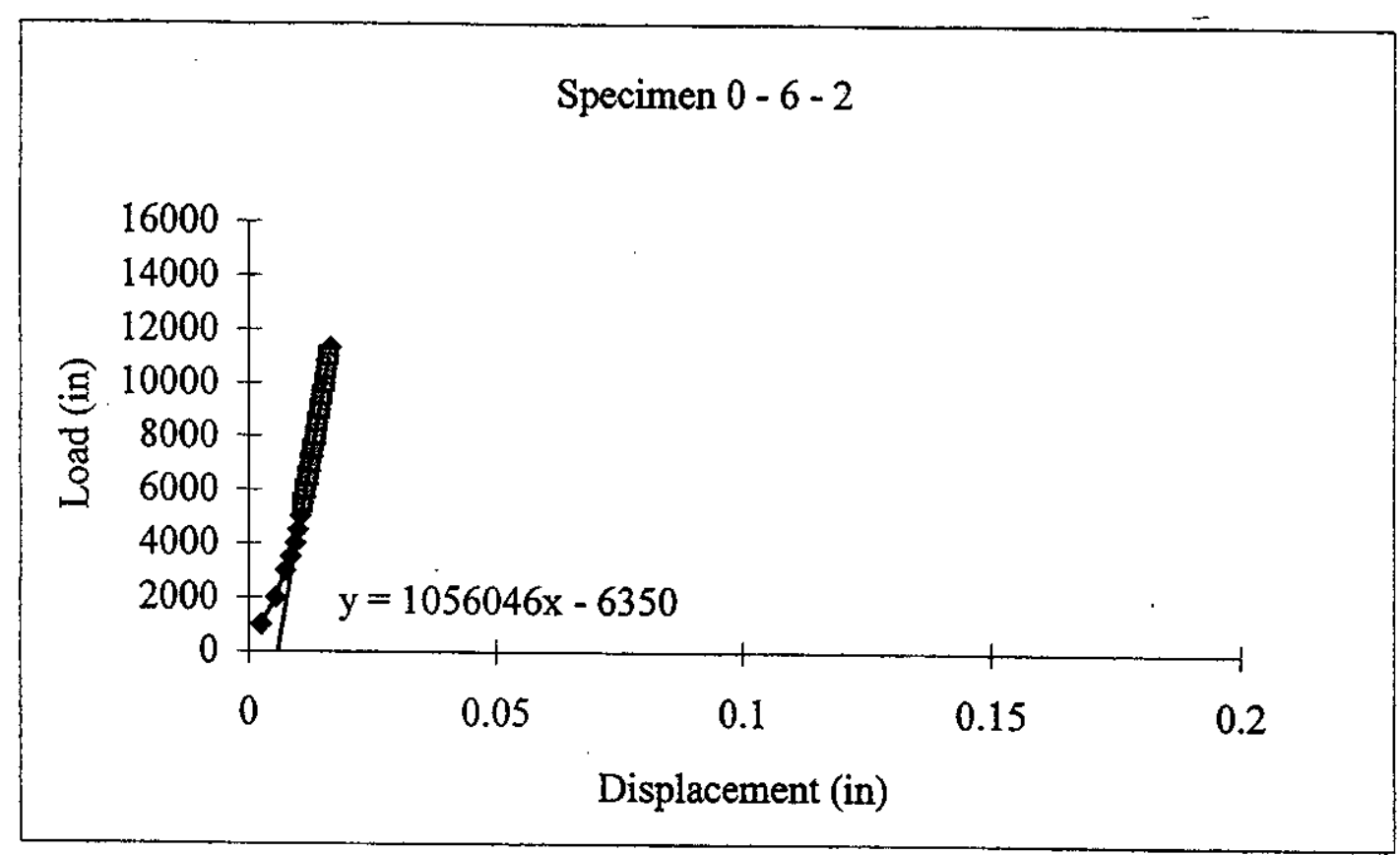

Figure E14: Load Deflection Curve for Specimen 0 - 6 - 2

Table E14: Load Deflection Data for Specimen 0 - 6 - 2

\begin{tabular}{|c|c|}
\hline $\begin{aligned} \text { First Crack Load } & =11,320 \\
\text { Midspan First Crack Deflection } & =0.0107 \\
\text { Modulus of Rupture } & =943 \\
\text { First Crack Toughness } & =60.56\end{aligned}$ & $\begin{array}{l}\text { lbs } \\
\text { in } \\
\text { psi } \\
\text { lb-in }\end{array}$ \\
\hline
\end{tabular}

Specimen Type $=$ Molded

Specimen Age $=28 \quad$ days

Specimen Abnormailities $=$ None

Cure $=$ Moist Room

Width $=6$ in

Depth $=6$ in

Span Length $=18$ in

$\mathrm{O}^{\prime}=0.006 \quad$ in 


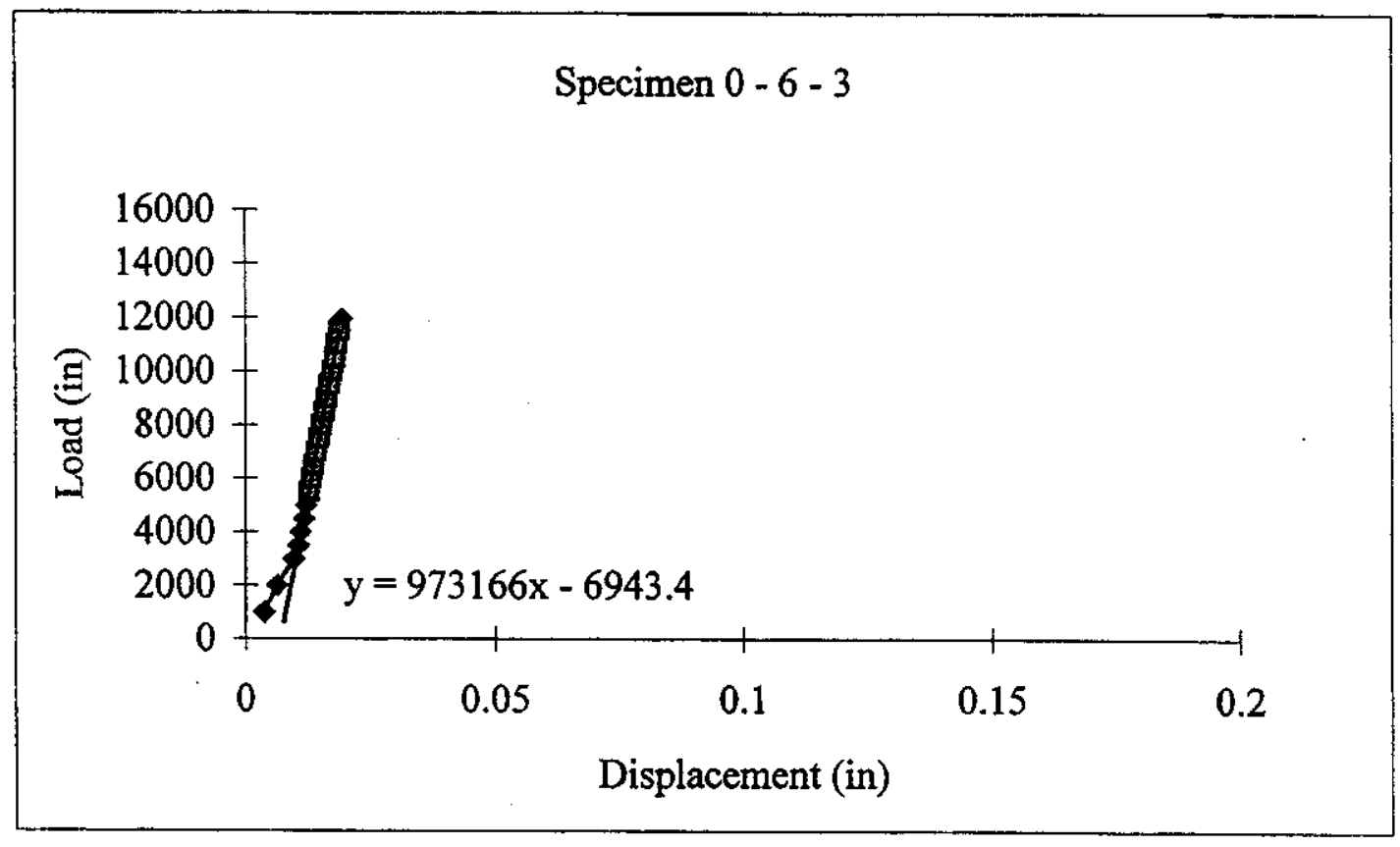

Figure E15: Load Deflection Curve for Specimen 0 - 6-3

Table E15: Load Deflection Data for Specimen 0 - 6 - 3

\begin{tabular}{|c|c|}
\hline $\begin{aligned} \text { First Crack Load } & =11,940 \\
\text { Midspan First Crack Deflection } & =0.0123 \\
\text { Modulus of Rupture } & =995 \\
\text { First Crack Toughness } & =73.43\end{aligned}$ & $\begin{array}{l}\text { lbs } \\
\text { in } \\
\text { psi } \\
\text { lb-in }\end{array}$ \\
\hline
\end{tabular}

Specimen Type $=$ Molded

Specimen Age $=28 \quad$ days

Specimen Abnormailities $=$ None

Cure $=$ Moist Room

Width $=6 \quad$ in

Depth $=6$ in

Span Length $=18$ in

$\mathrm{O}^{\prime}=0.0071 \quad$ in 


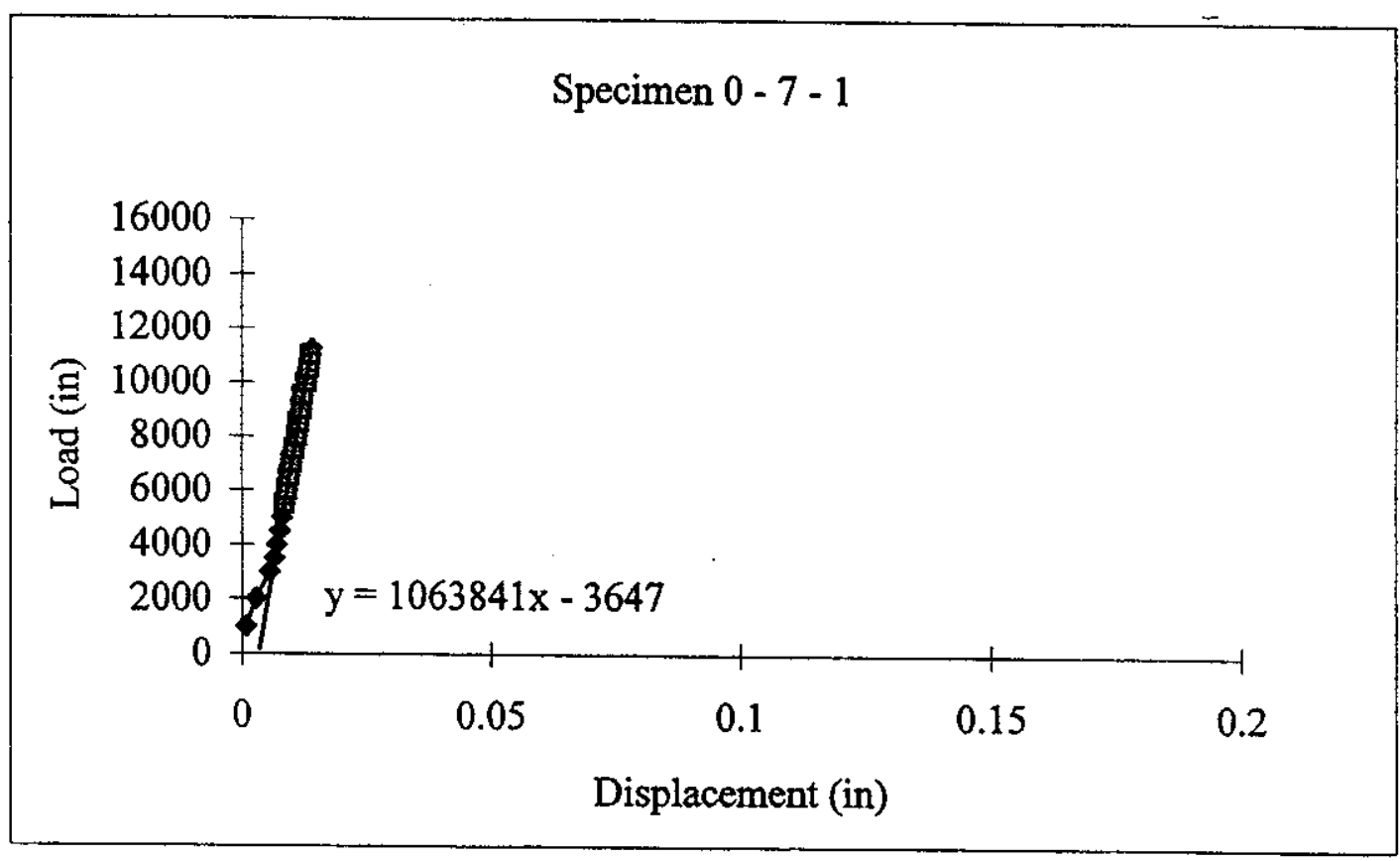

Figure E16: Load Deflection Curve for Specimen 0 - 7 - 1

Table E16: Load Deflection Data for Specimen 0 - 7 - 1

\begin{tabular}{|c|c|}
\hline $\begin{aligned} \text { First Crack Load } & =11,250 \\
\text { Midspan First Crack Deflection } & =0.0106 \\
\text { Modulus of Rupture } & =938 \\
\text { First Crack Toughness } & =59.63\end{aligned}$ & $\begin{array}{l}\text { Ibs } \\
\text { in } \\
\text { psi } \\
\text { lb-in }\end{array}$ \\
\hline
\end{tabular}

Specimen Type $=$ Molded

Specimen Age $=28$ days

Specimen Abnormailities $=$ None

$$
\begin{array}{rlr}
\text { Cure } & =\text { Moist Room } \\
\text { Width } & =6 & \text { in } \\
\text { Depth } & =6 & \text { in } \\
\text { Span Length } & =18 & \text { in } \\
O^{\prime} & =0.0034 & \text { in }
\end{array}
$$




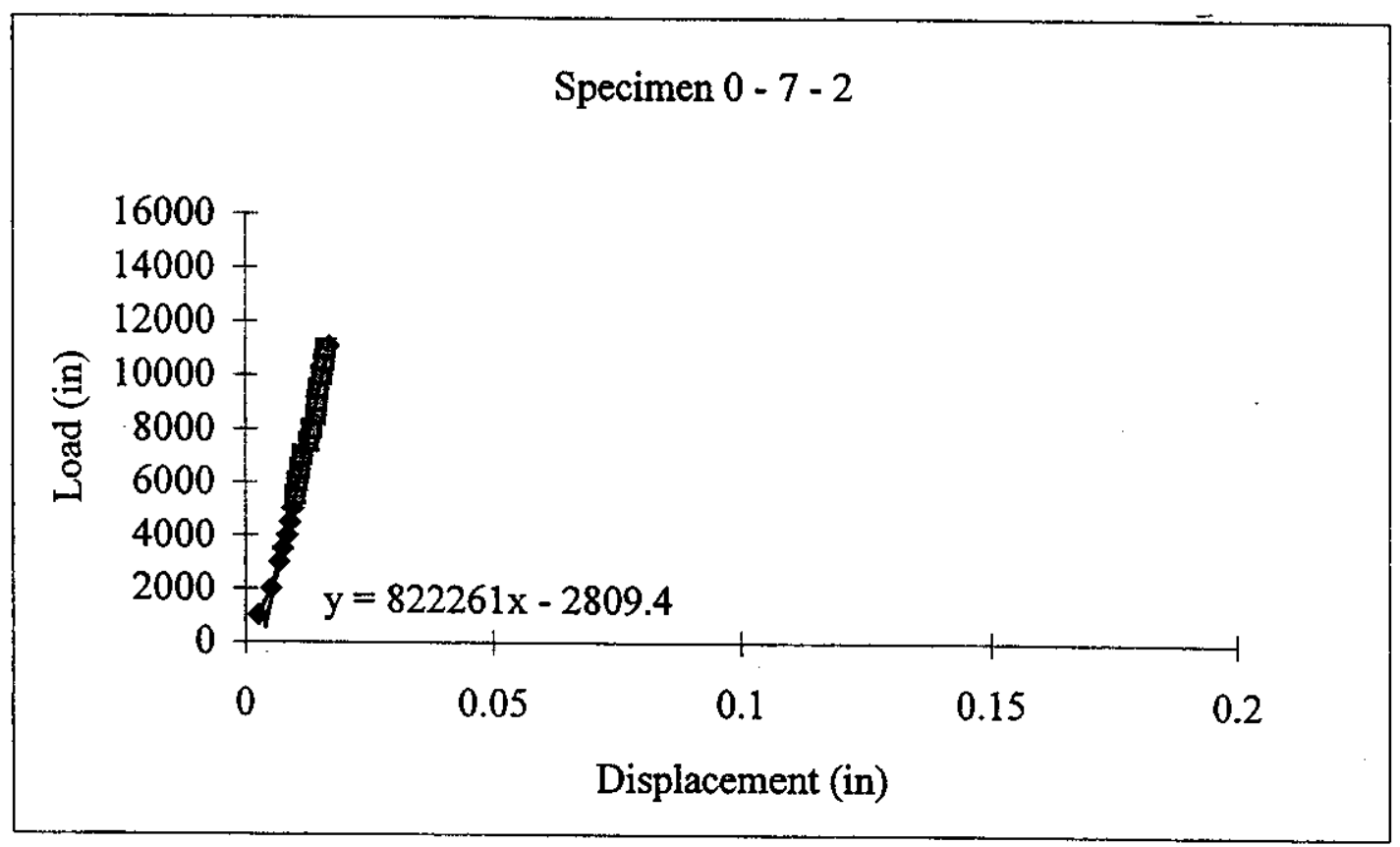

Figure E17: Load Deflection Curve for Specimen 0 - 7 - 2

Table E17: Load Deflection Data for Specimen 0 - 7 -2

\begin{tabular}{|c|c|}
\hline $\begin{aligned} \text { First Crack Load } & =11,100 \\
\text { Aidspan First Crack Deflection } & =0.0135 \\
\text { Modulus of Rupture } & =925 \\
\text { First Crack Toughness } & =74.93\end{aligned}$ & $\begin{array}{l}\text { lbs } \\
\text { in } \\
\text { psi } \\
\text { lb-in }\end{array}$ \\
\hline
\end{tabular}

Specimen Type $=$ Molded

Specimen Age $=28 \quad$ days

Specimen Abnormailities $=$ None

Cure $=$ Moist Room

Width $=6$ in

Depth $=6$ in

Span Length $=18$ in

$\mathrm{O}^{\prime}=0.0034$ in 


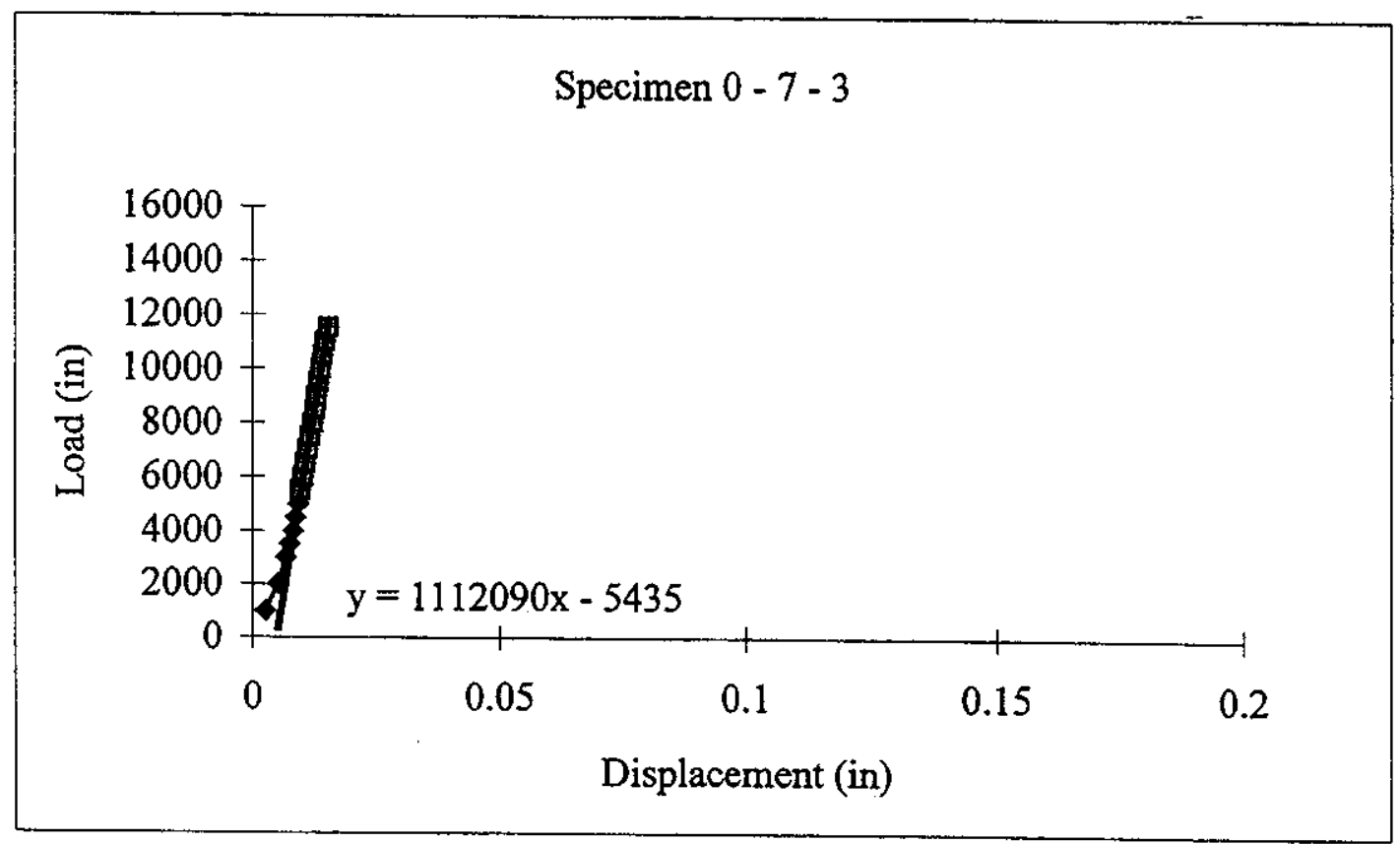

Figure E18: Load Deflection Curve for Specimen 0 - 7 - 3

Table E18: Load Deflection Data for Specimen 0 - 7 - 3

\begin{tabular}{|c|c|}
\hline $\begin{aligned} \text { First Crack Load } & =11,540 \\
\text { Midspan First Crack Deflection } & =0.0104 \\
\text { Modulus of Rupture } & =962 \\
\text { First Crack Toughness } & =60.01\end{aligned}$ & $\begin{array}{l}\text { lbs } \\
\text { in } \\
\text { psi } \\
\text { lb-in }\end{array}$ \\
\hline
\end{tabular}

Specimen Type $=$ Molded

$$
\text { Specimen Age }=28 \text { days }
$$

Specimen Abnormailities $=$ None

Cure $=$ Moist Room

Width $=6$ in

Depth $=6$ in

Span Length $=18 \quad$ in

$$
\mathrm{O}^{\prime}=0.0049 \text { in }
$$




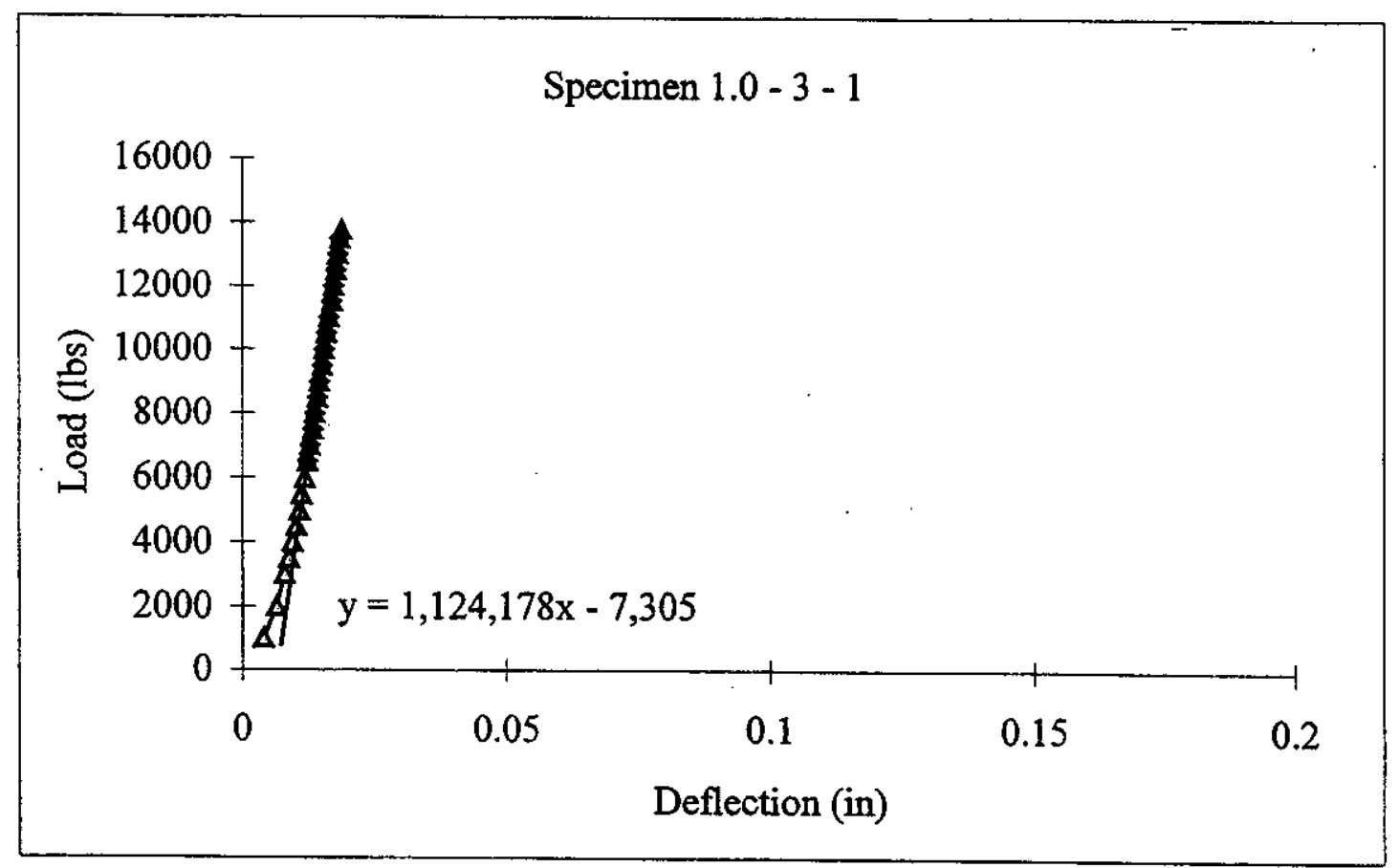

Figure E19: Load Deflection Curve for Specimen 1.0 - 3 - 1

Table E19: Load Deflection Data for Specimen 1.0 - 3 - 1

\begin{tabular}{|c|c|}
\hline $\begin{aligned} \text { First Crack Load } & =13,740 \\
\text { Midspan First Crack Deflection } & =0.0122 \\
\text { Modulus of Rupture } & =1145 \\
\text { First Crack Toughness } & =83.81\end{aligned}$ & $\begin{array}{l}\text { lbs } \\
\text { in } \\
\text { psi } \\
\text { lb-in }\end{array}$ \\
\hline
\end{tabular}

Specimen Type $=$ Molded

Specimen Age $=28 \quad$ DAYS

Specimen Abnormailities $=$ None

Cure $=$ Moist Room

Width $=6$. in

Depth $=6$ in

Span Length $=18$ in

$\mathrm{O}^{\prime}=0.0065$ in 


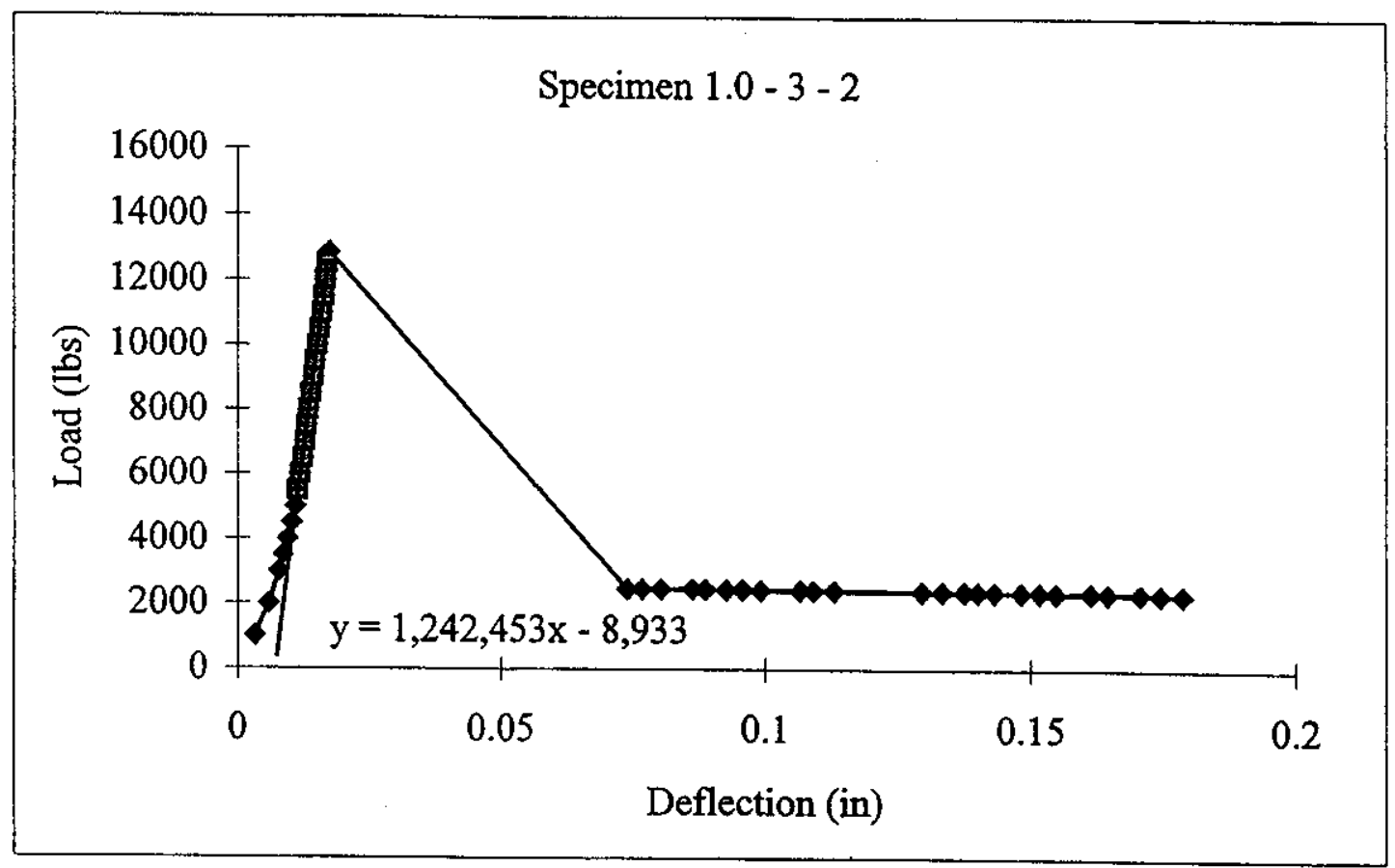

Figure E20: Load Deflection Curve for Specimen 1.0 - 3 - 2

Table E20: Load Deflection Data for Specimen 1.0 - 3 - 2

\begin{tabular}{|c|c|}
\hline $\begin{aligned} \text { First Crack Load } & =12,850 \\
\text { Midspan First Crack Deflection } & =0.0103 \\
\text { Modulus of Rupture } & =1070.8 \\
\text { First Crack Toughness } & =66.24\end{aligned}$ & $\begin{array}{l}\text { lbs } \\
\text { in } \\
\text { psi } \\
\text { lb-in }\end{array}$ \\
\hline
\end{tabular}

Specimen Type $=$ Molded

Specimen Age $=28$

DAYS

Specimen Abnormailities $=$ None

$$
\begin{array}{rlr}
\text { Cure } & =\text { Moist Room } \\
\text { Width } & =6 & \text { in } \\
\text { Depth } & =6 & \text { in } \\
\text { Span Length } & =18 & \text { in } \\
O^{\prime} & =0.00719 & \text { in }
\end{array}
$$




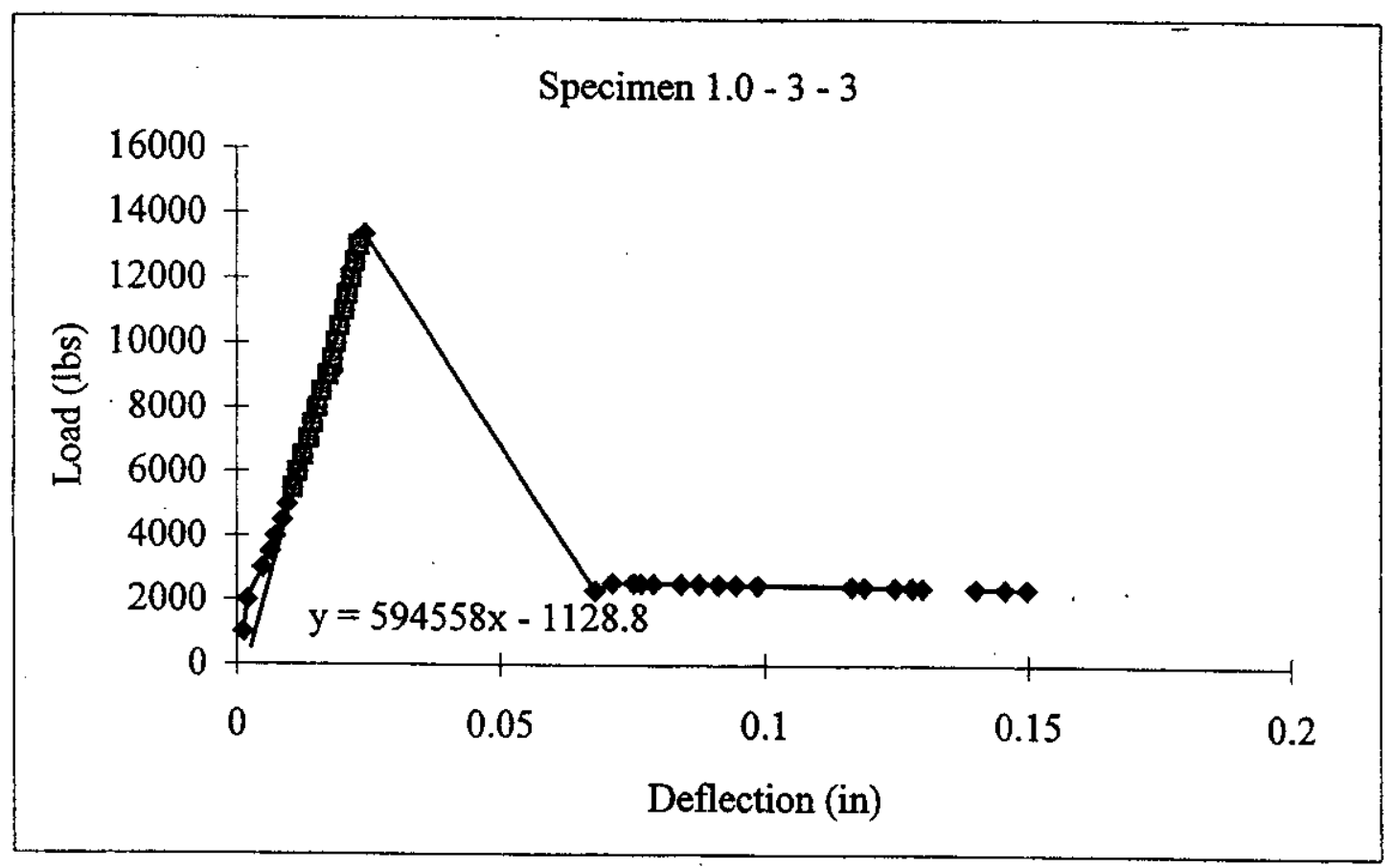

Figure E21: Load Deflection Curve for Specimen $1.0-3-3$

Table E21: Load Deflection Data for Specimen 1.0 - 3 - 3

\begin{tabular}{|rl|}
\hline First Crack Load $=13,350$ & lbs \\
Midspan First Crack Deflection $=0.0225$ & in \\
Modulus of Rupture $=1112.5$ & psi \\
First Crack Toughness $=150.19$ & lb-in \\
\hline
\end{tabular}

Specimen Type $=$ Molded

Specimen Age $=28$

DAYS

Specimen Abnormailities $=$ None

Cure $=$ Moist Room

Width $=6 \quad$ in

Depth $=6$ in

Span Length $=18$ in

$\mathrm{O}^{\prime}=0.0019$ in 


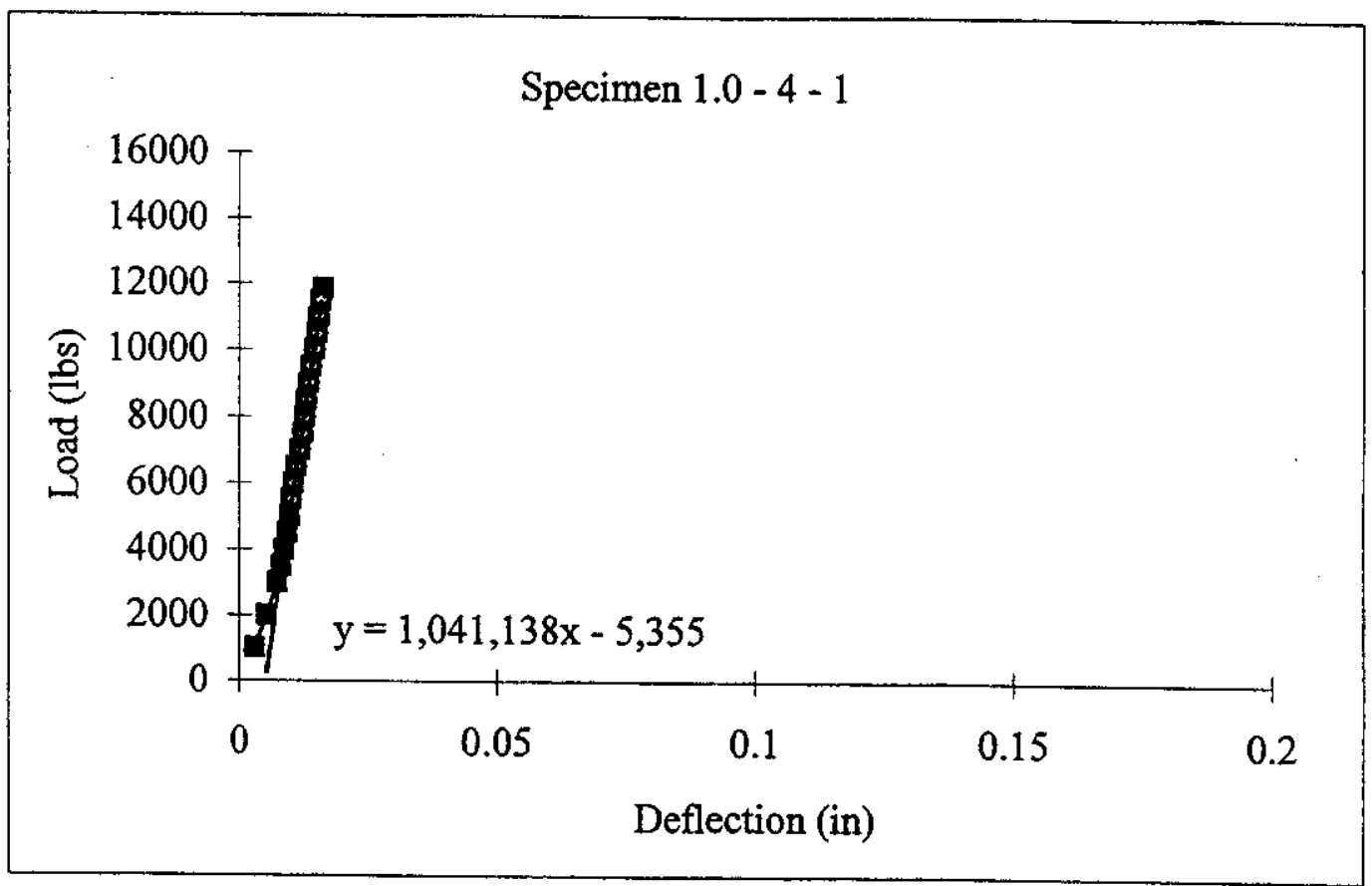

Figure E22: Load Deflection Curve for Specimen 1.0 - 4 - 1

Table E22: Load Deflection Data for Specimen 1.0 - 4 - 1

\begin{tabular}{|c|c|}
\hline $\begin{aligned} \text { First Crack Load } & =11,860 \\
\text { Midspan First Crack Deflection } & =0.0114 \\
\text { Modulus of Rupture } & =988 \\
\text { First Crack Toughness } & =67.60\end{aligned}$ & $\begin{array}{l}\text { lbs } \\
\text { in } \\
\text { psi } \\
\text { lb-in }\end{array}$ \\
\hline
\end{tabular}

Specimen Type $=$ Molded

Specimen Age $=28 \quad$ DAYS

Specimen Abnormailities $=$ None

Cure $=$ Moist Room

Width $=6 \quad$ in

Depth $=6$ in

Span Length $=18$ in

$\mathrm{O}^{\prime}=0.0051$ in 


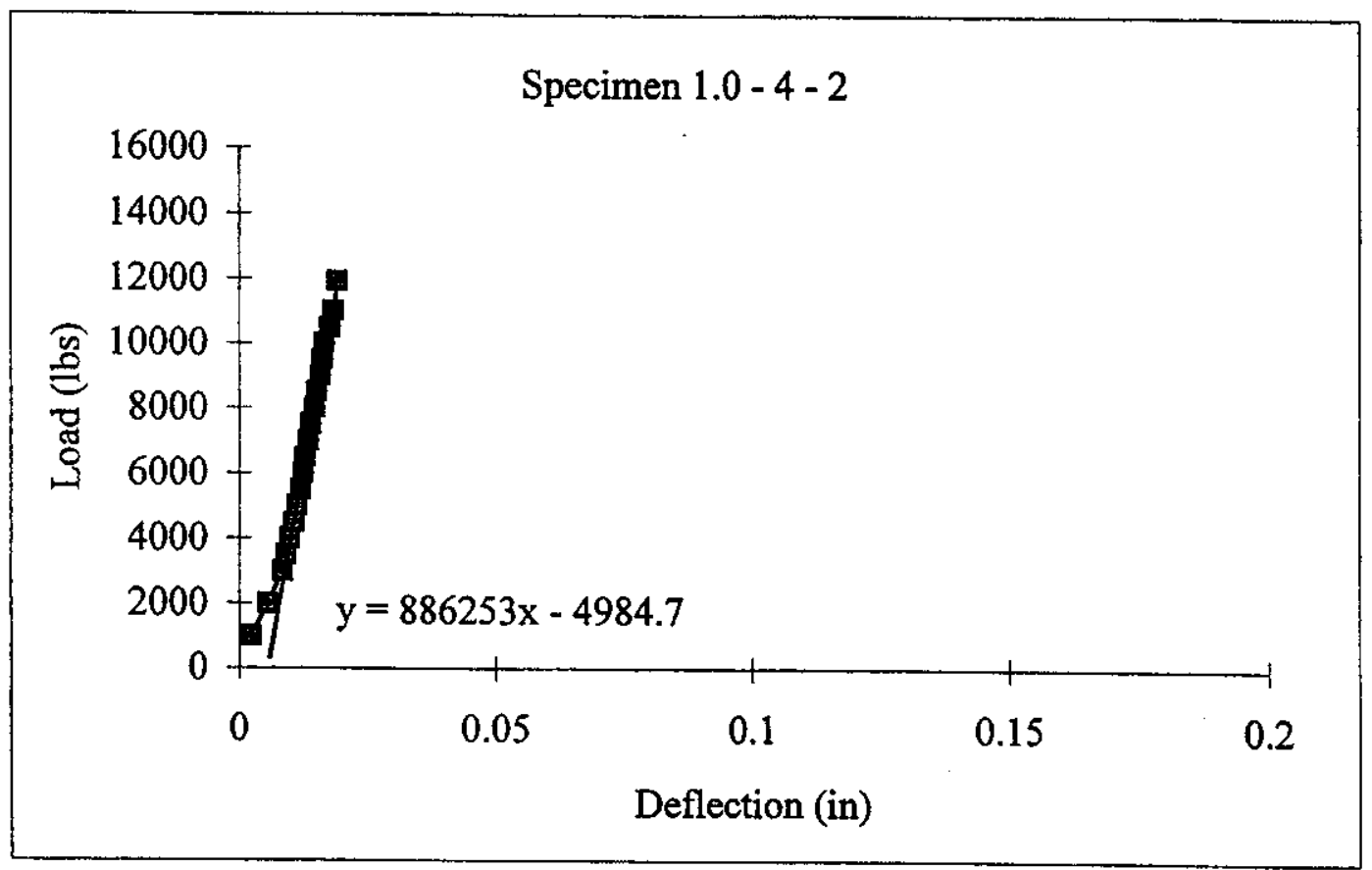

Figure E23: Load Deflection Curve for Specimen 1.0 - 4 - 2

Table E23: Load Deflection Data for Specimen 1.0 - 4 - 2

\begin{tabular}{|c|c|}
\hline $\begin{aligned} \text { First Crack Load } & =11,940 \\
\text { Midspan First Crack Deflection } & =0.0116 \\
\text { Modulus of Rupture } & =995 \\
\text { First Crack Toughness } & =69.25\end{aligned}$ & $\begin{array}{l}\text { lbs } \\
\text { in } \\
\text { psi } \\
\text { lb-in }\end{array}$ \\
\hline
\end{tabular}

Specimen Type $=$ Molded

Specimen Age $=28 \quad$ DAYS

Specimen Abnormailities $=$ None

Cure $=$ Moist Room

Width $=6 \quad$ in

Depth $=6$. in

Span Length $=18$ in

$\mathrm{O}^{\prime}=0.0075$ in 


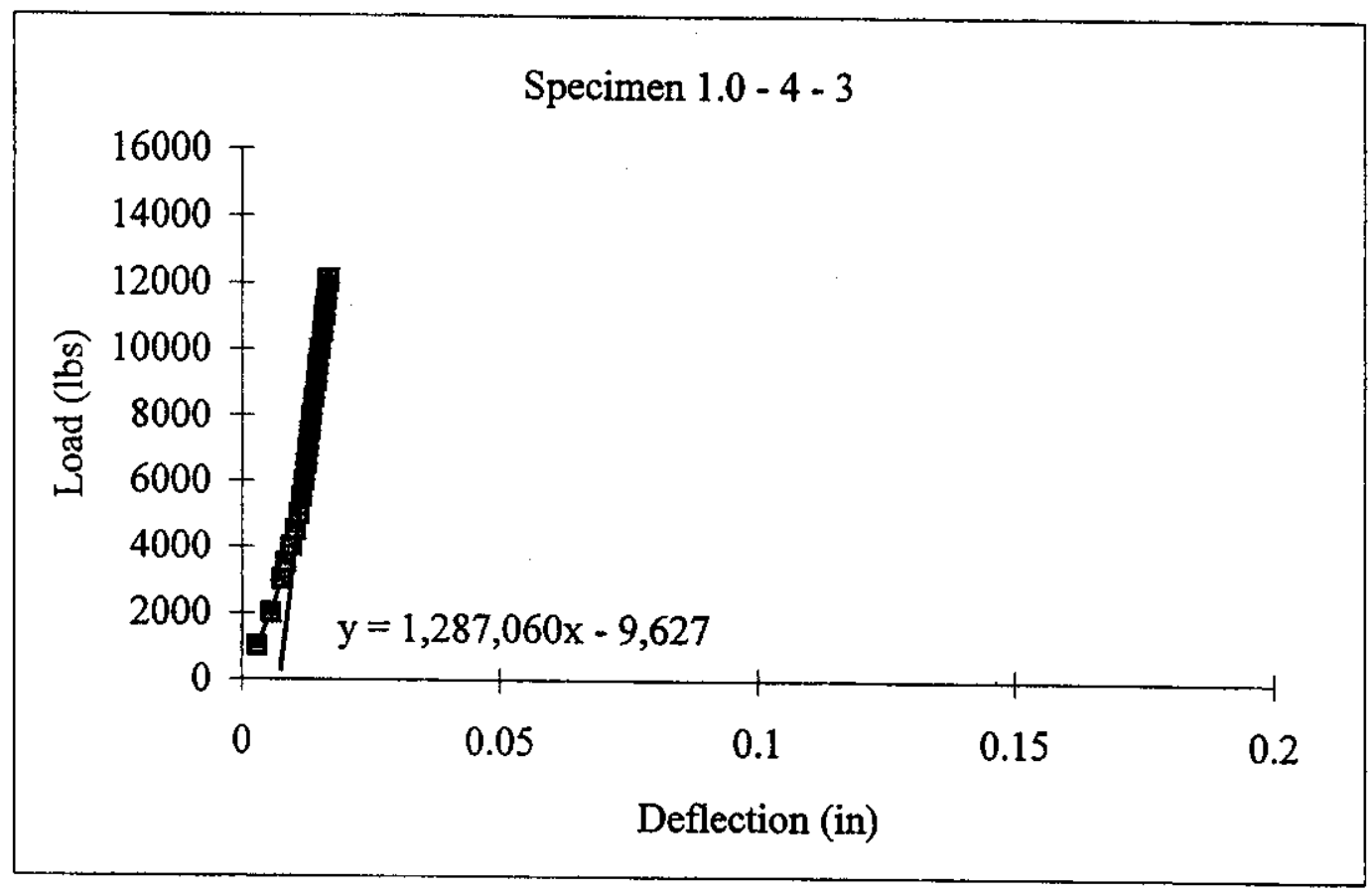

Figure E24: Load Deflection Curve for Specimen 1.0 - 4 - 3

Table E24: Load Deflection Data for Specimen 1.0 - 4 - 3

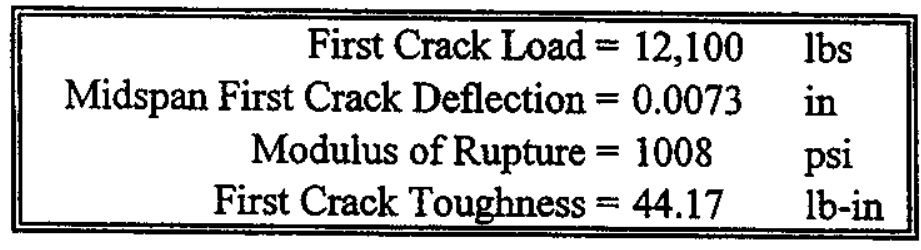

Specimen Type $=$ Molded

$$
\text { Specimen Age }=28 \quad \text { DAYS }
$$

Specimen Abnormailities $=$ None

Cure $=$ Moist Room

Width $=6$ in

Depth $=6$ in

Span Length $=18$ in

$\mathrm{O}^{\prime}=0.0096 \quad$ in 


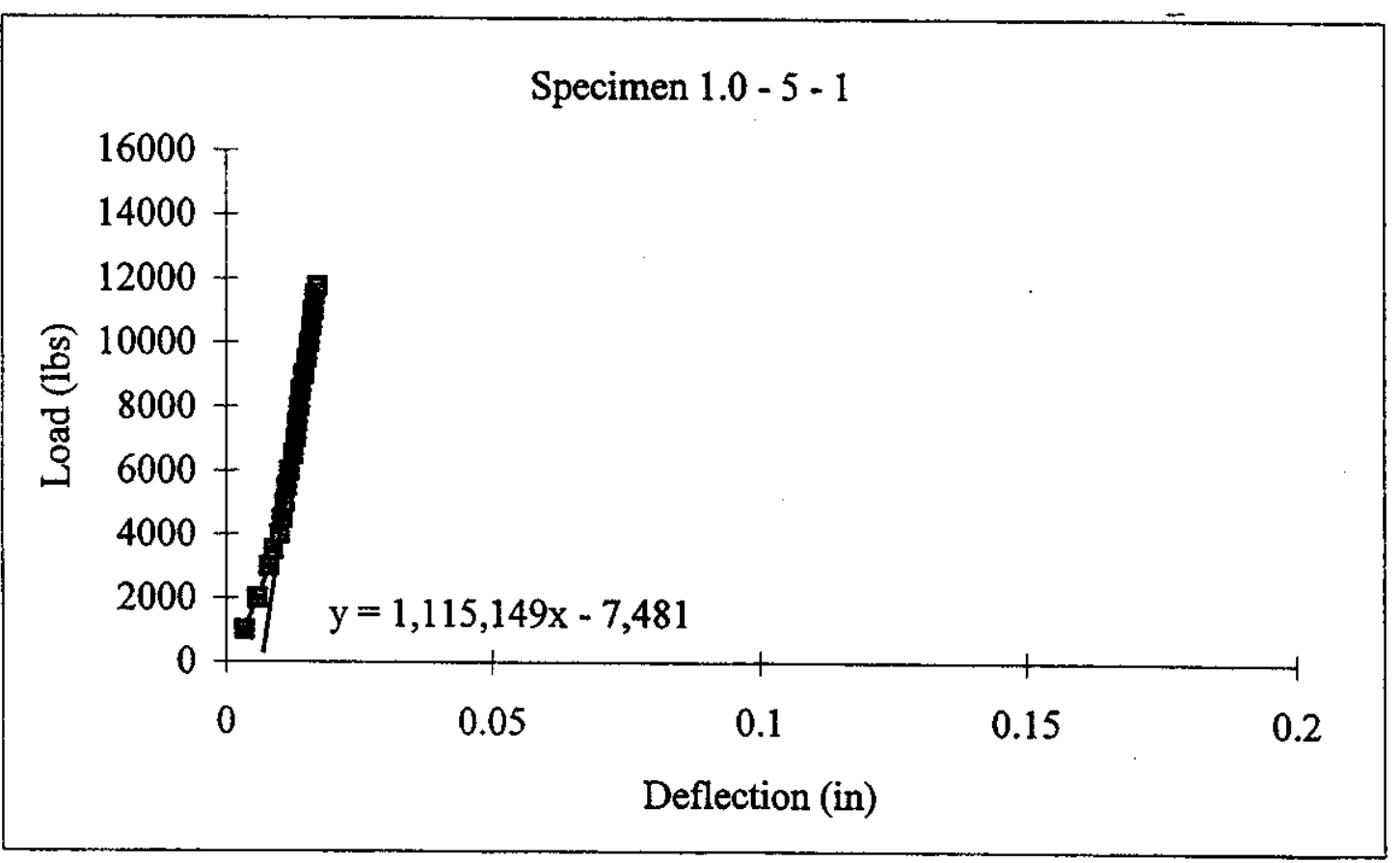

Figure E25: Load Deflection Curve for Specimen 1.0 - 5 - 1

Table E25: Load Deflection Data for Specimen 1.0 - 5 - 1

\begin{tabular}{|c|c|}
\hline $\begin{aligned} \text { First Crack Load } & =11,760 \\
\text { Midspan First Crack Deflection } & =0.0106 \\
\text { Modulus of Rupture } & =980 \\
\text { First Crack Toughness } & =62.33\end{aligned}$ & $\begin{array}{l}\text { Ibs } \\
\text { in } \\
\text { psi } \\
\text { lb-in }\end{array}$ \\
\hline
\end{tabular}

$$
\text { Specimen Type }=\text { Molded }
$$

Specimen Age $=28$

DAYS

Specimen Abnormailities $=$ None

Cure $=$ Moist Room

Width $=6 \quad$ in

Depth $=6$ in

Span Length $=18$ in

$\mathrm{O}^{\prime}=0.0067$ in 


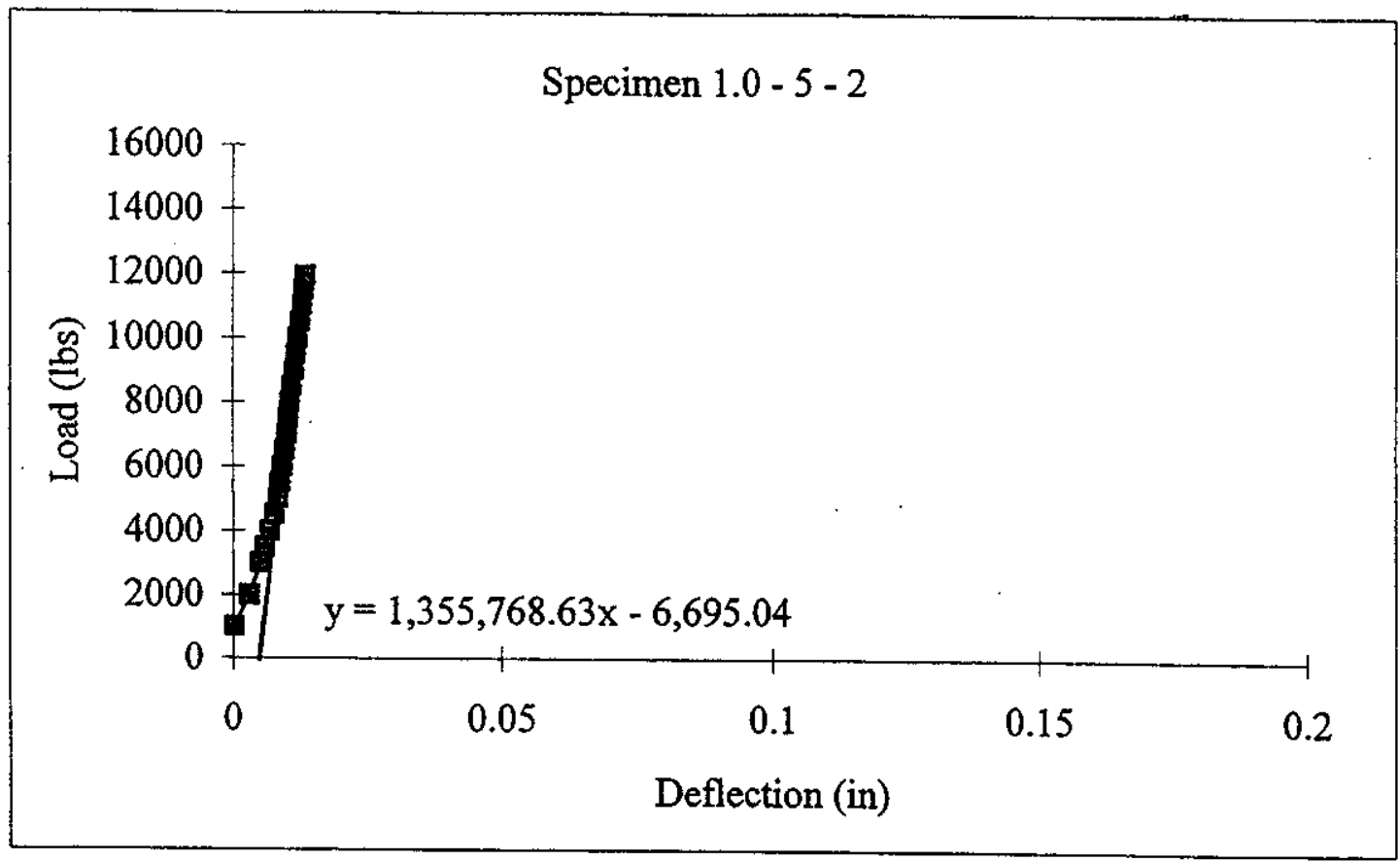

Figure E26: Load Deflection Curve for Specimen 1.0 - 5 - 2

Table E26: Load Deflection Data for Specimen 1.0 - 5 - 2

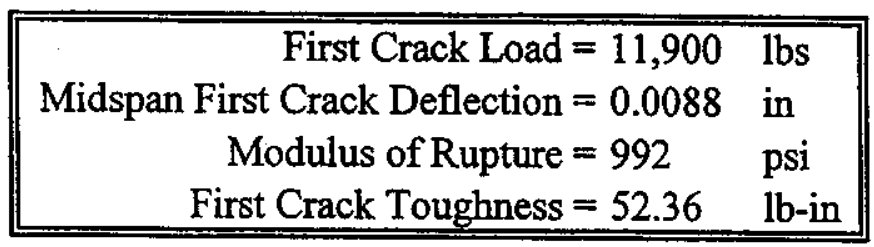

Specimen Type $=$ Molded

Specimen Age $=28 \quad$ DAYS

Specimen Abnormailities $=$ None

Cure $=$ Moist Room

Width $=6 \quad$ in

Depth $=6$ in

Span Length $=18 \quad$ in

$$
\mathrm{O}^{\prime}=0.0049 \text { in }
$$




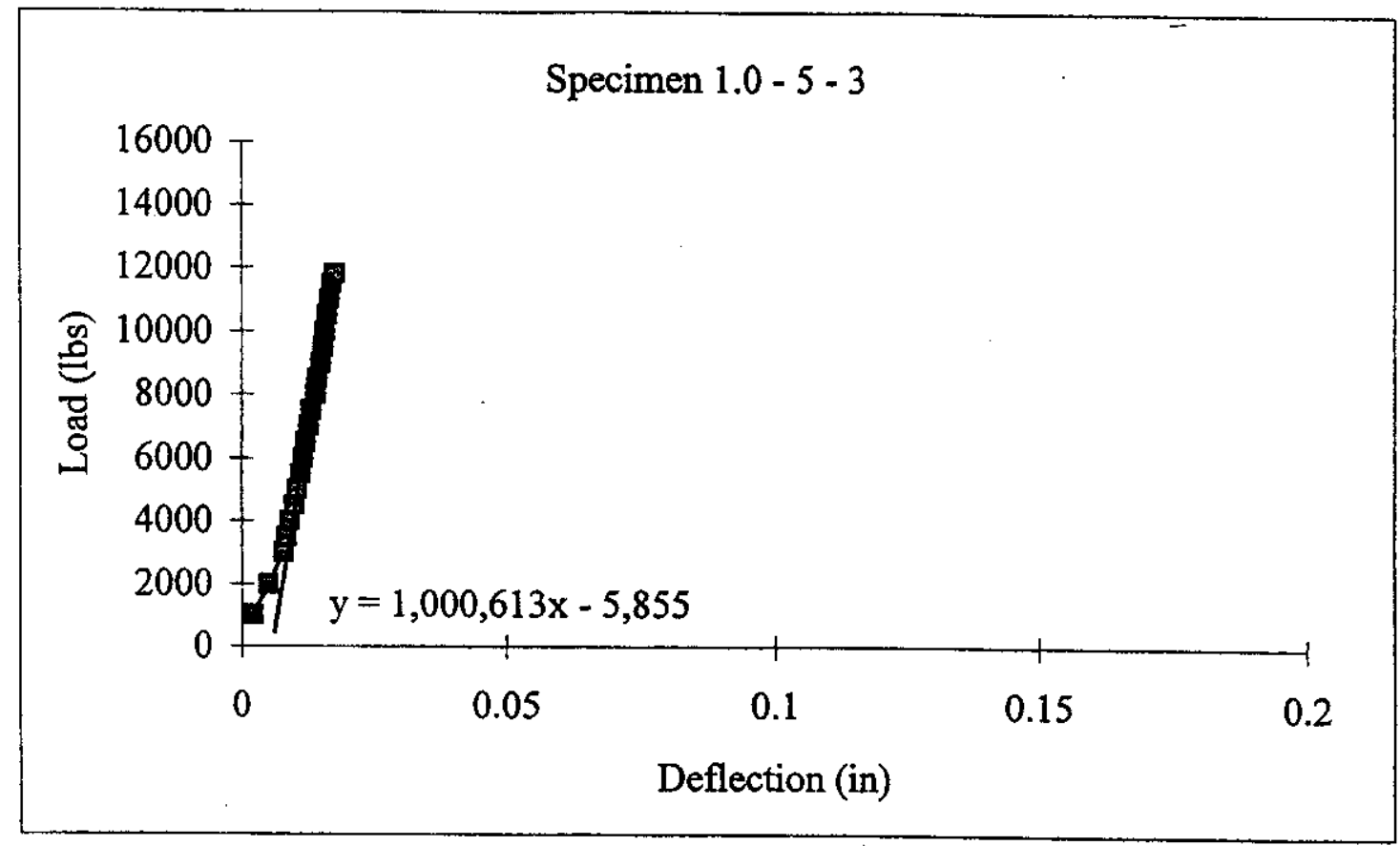

Figure E27: Load Deflection Curve for Specimen 1.0 - 5 - 3

Table E27: Load Deflection Data for Specimen 1.0 - 5 - 3

\begin{tabular}{|c|c|}
\hline $\begin{aligned} \text { First Crack Load } & =11,810 \\
\text { Midspan First Crack Deflection } & =0.0118 \\
\text { Modulus of Rupture } & =984 \\
\text { First Crack Toughness } & =69.68\end{aligned}$ & $\begin{array}{l}\text { lbs } \\
\text { in } \\
\text { psi } \\
\text { lb-in }\end{array}$ \\
\hline
\end{tabular}

Specimen Type $=$ Molded

Specimen Age $=28 \quad$ DAYS

Specimen Abnormailities $=$ None

Cure $=$ Moist Room

Width $=6 \quad$ in

Depth $=6$ in

Span Length $=18$ in

$\mathrm{O}^{\prime}=0.0059$ in 


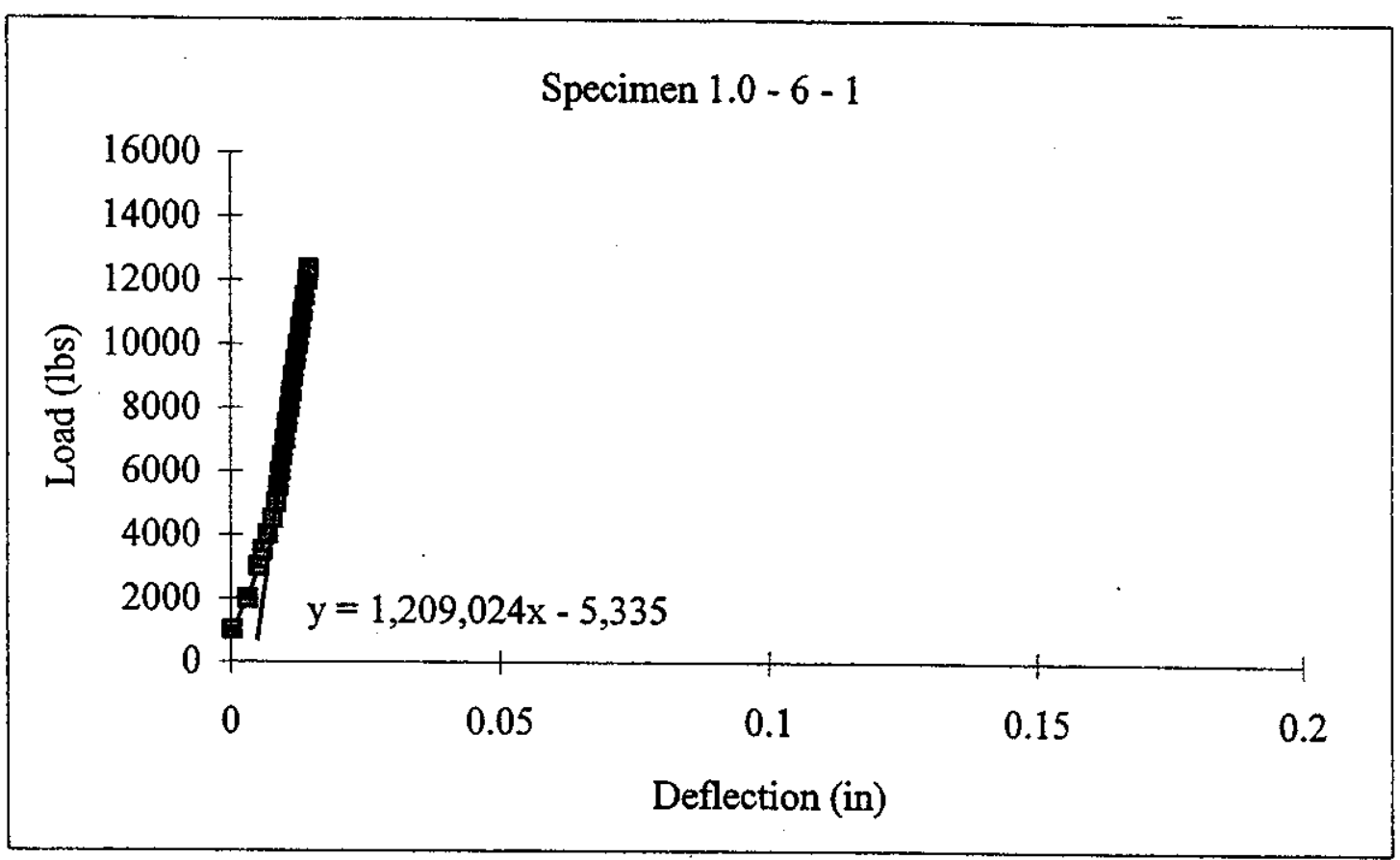

Figure E28: Load Deflection Curve for Specimen 1.0 - 6 - 1

Table E28: Load Deflection Data for Specimen 1.0 - 6 - 1

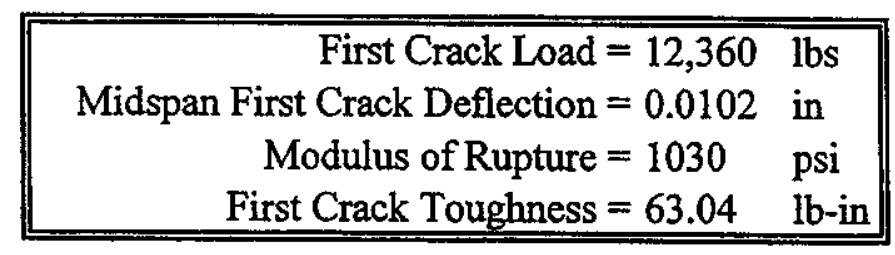

Specimen Type $=$ Molded

Specimen Age $=28 \quad$ DAYS

Specimen Abnormailities $=$ None

Cure $=$ Moist Room

Width $=6$ in

Depth $=6$ in

Span Length $=18$ in

$\mathrm{O}^{\prime}=0.0044$ in 


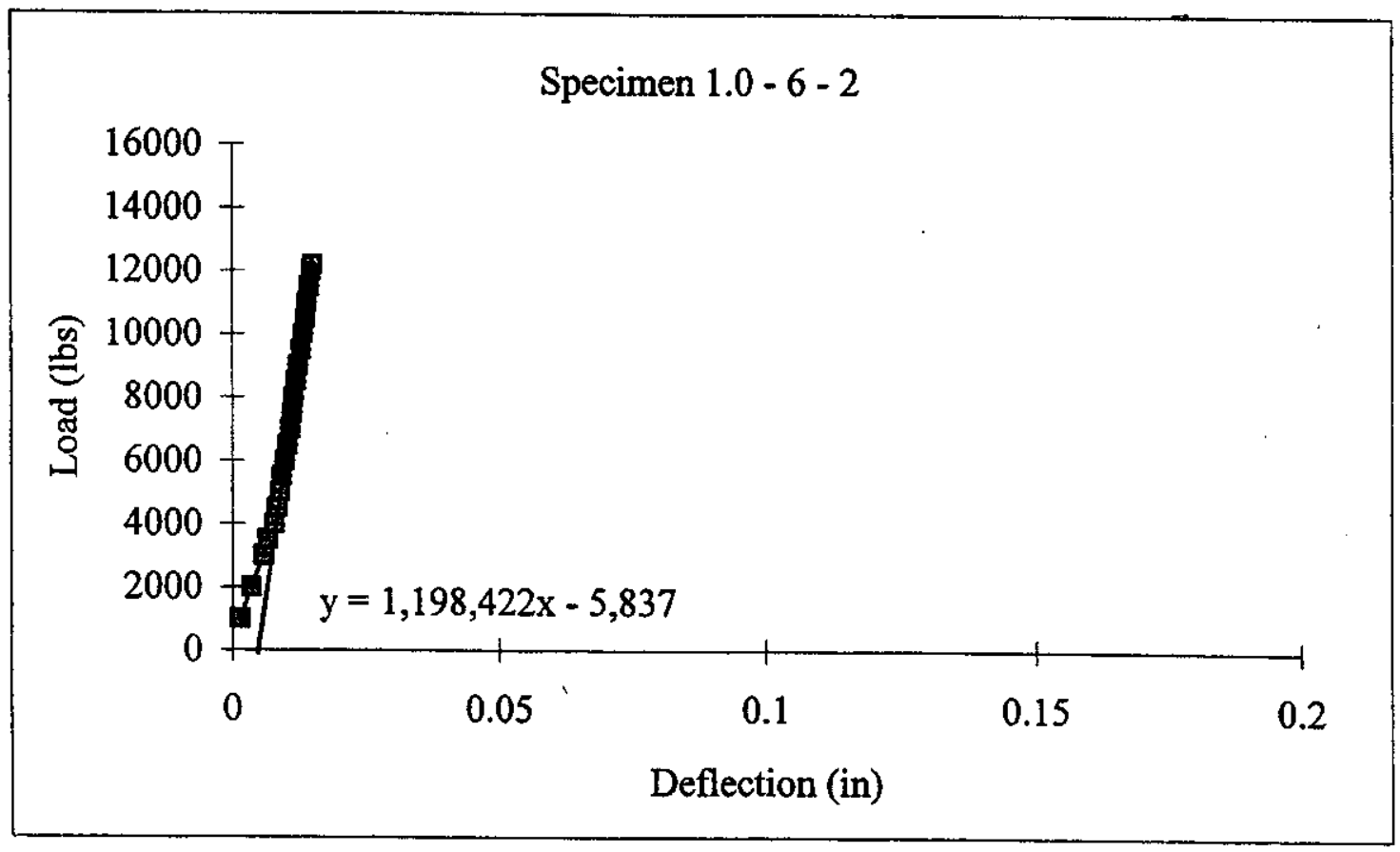

Figure E29: Load Deflection Curve for Specimen 1.0 - 6 - 2

Table E29: Load Deflection Data for Specimen 1.0 - 6 - 2

\begin{tabular}{|c|c|}
\hline $\begin{aligned} \text { First Crack Load } & =12,180 \\
\text { Midspan First Crack Deflection } & =0.0101 \\
\text { Modulus of Rupture } & =1015 \\
\text { First Crack Toughness } & =61.51\end{aligned}$ & $\begin{array}{l}\text { lbs } \\
\text { in } \\
\text { psi } \\
\text { lb-in }\end{array}$ \\
\hline
\end{tabular}

Specimen Type $=$ Molded

Specimen Age $=28 \quad$ DAYS

Specimen Abnormailities $=$ None

Cure $=$ Moist Room

Width $=6 \quad$ in

Depth $=6$ in

Span Length $=18$ in

$\mathrm{O}^{\prime}=0.0049$ in 


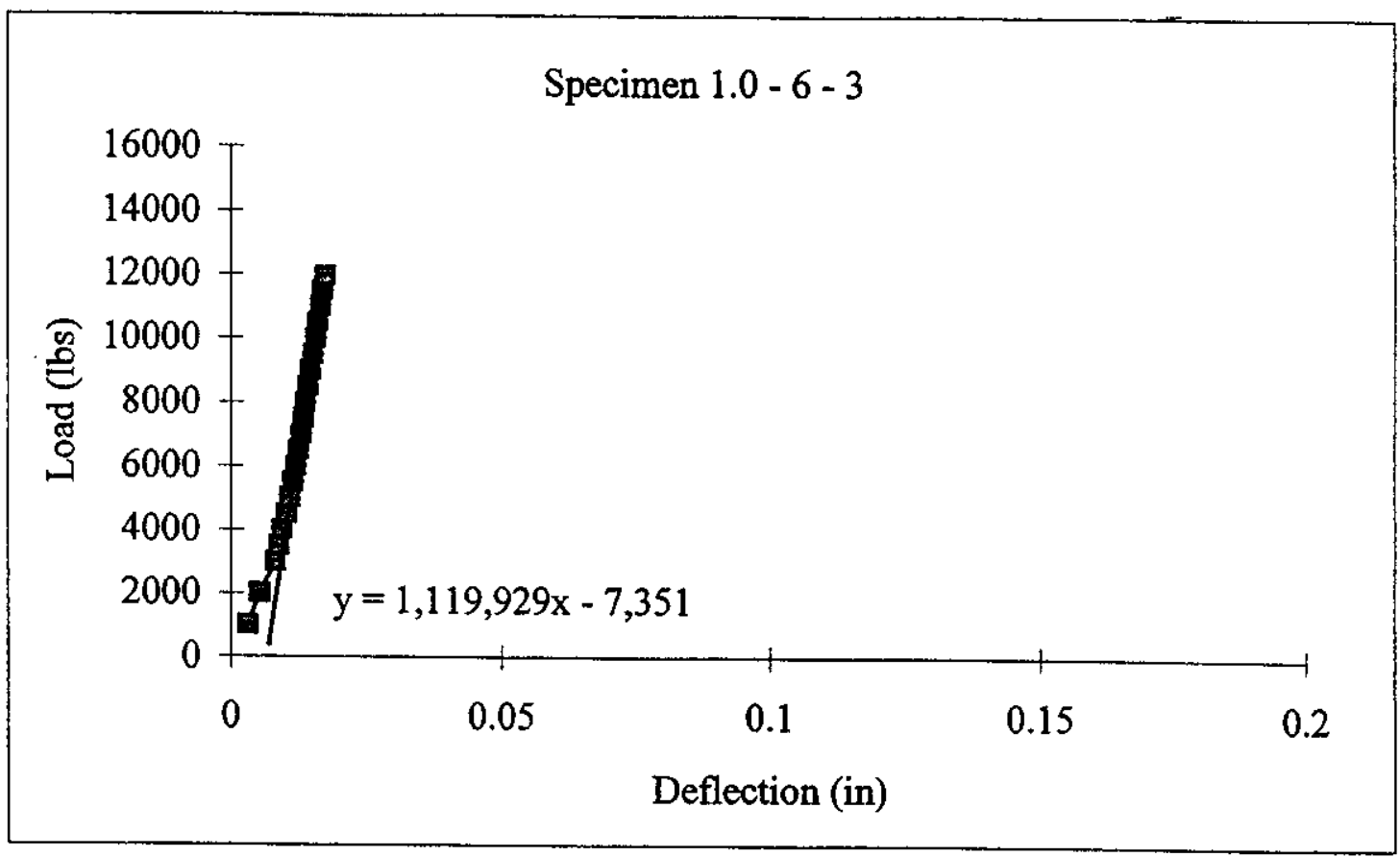

Figure E30: Load Deflection Curve for Specimen 1.0 - 6 - 3

Table E30: Load Deflection Data for Specimen 1.0 - 6 - 3

\begin{tabular}{|c|c|}
\hline $\begin{aligned} \text { First Crack Load } & =11,970 \\
\text { Midspan First Crack Deflection } & =0.0107 \\
\text { Modulus of Rupture } & =998 \\
\text { First Crack Toughness } & =64.04\end{aligned}$ & $\begin{array}{l}\text { lbs } \\
\text { in } \\
\text { psi } \\
\text { lb-in }\end{array}$ \\
\hline
\end{tabular}

Specimen Type $=$ Molded

Specimen Age $=28 \quad$ DAYS

Specimen Abnormailities $=$ None

Cure $=$ Moist Room

Width $=6 \quad$ in

Depth $=6 \quad$ in

Span Length $=18$ in

$\mathrm{O}^{\prime}=0.0066$ in 


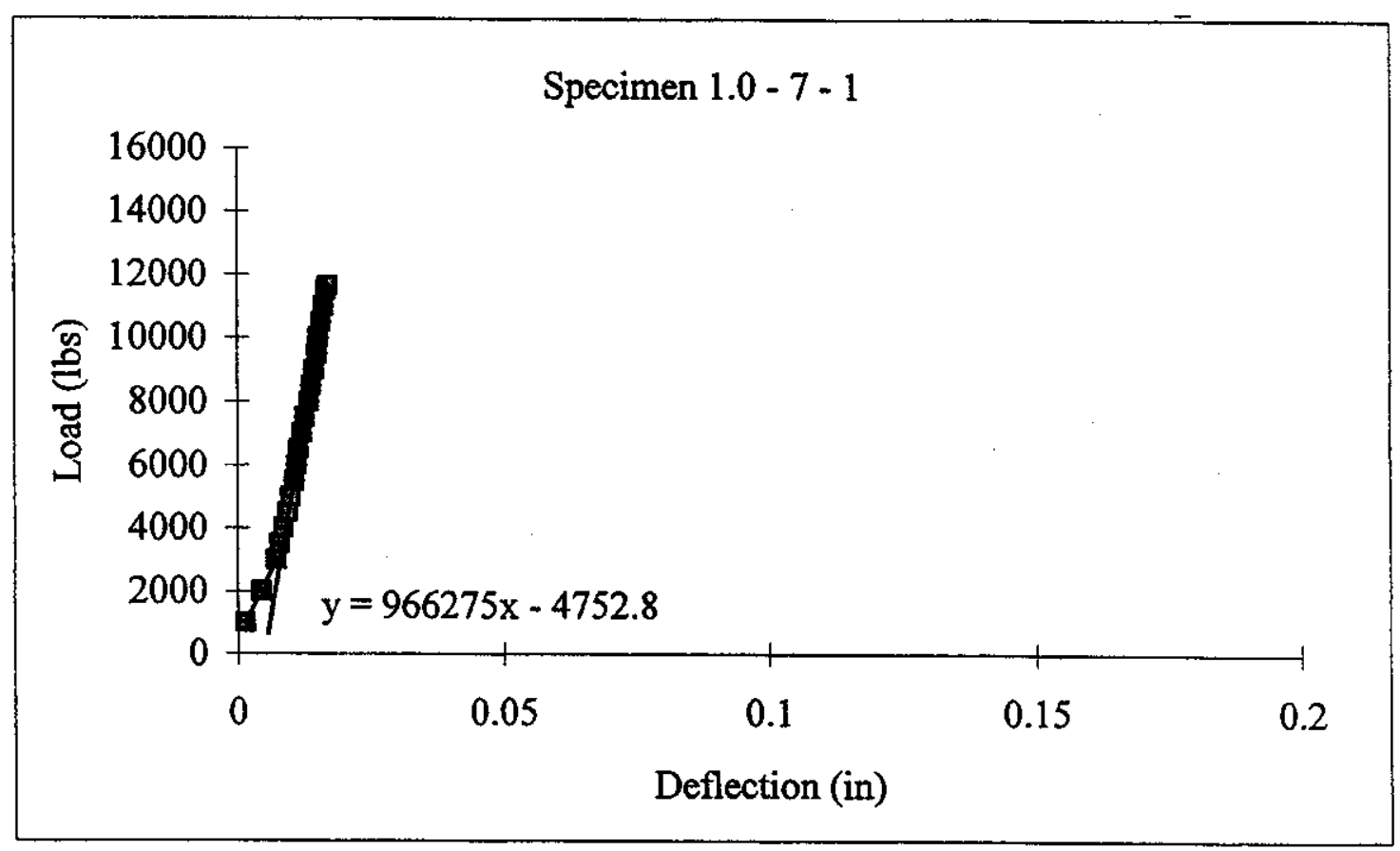

Figure E31: Load Deflection Curve for Specimen 1.0 - 7 - 1

Table E31: Load Deflection Data for Specimen 1.0 - 7 - 1

\begin{tabular}{|c|c|}
\hline $\begin{aligned} \text { First Crack Load } & =11,640 \\
\text { Midspan First Crack Deflection } & =0.0121 \\
\text { Modulus of Rupture } & =970 \\
\text { First Crack Toughness } & =70.42\end{aligned}$ & $\begin{array}{l}\text { lbs } \\
\text { in } \\
\text { psi } \\
\text { lb-in }\end{array}$ \\
\hline
\end{tabular}

Specimen Type $=$ Molded

Specimen Age $=28 \quad$ DAYS

Specimen Abnormailities $=$ None

Cure $=$ Moist Room

Width $=6 \quad$ in

Depth $=6$ in

Span Length $=18$ in

$\mathrm{O}^{\prime}=0.0049$ in 


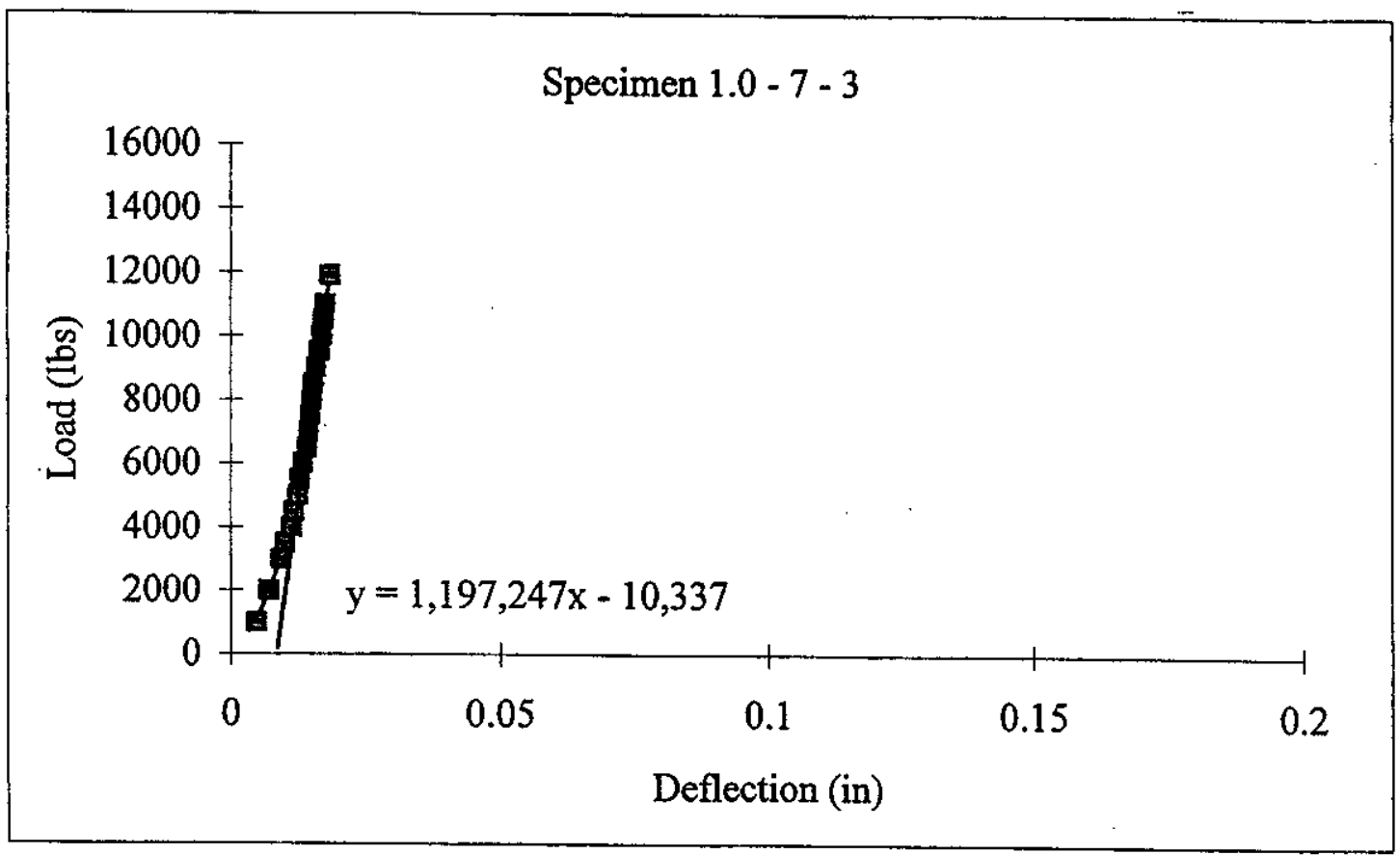

Figure E33: Load Deflection Curve for Specimen 1.0 - 7 - 3

Table E33: Load Deflection Data for Specimen 1.0 - 7 - 3

\begin{tabular}{|c|c|}
\hline $\begin{aligned} \text { First Crack Load } & =11,900 \\
\text { Midspan First Crack Deflection } & =0.01 \\
\text { Modulus of Rupture } & =992 \\
\text { First Crack Toughness } & =59.50\end{aligned}$ & $\begin{array}{l}\text { Ibs } \\
\text { in } \\
\text { psi } \\
\text { lb-in }\end{array}$ \\
\hline
\end{tabular}

$\begin{array}{rlrl}\text { Specimen Type } & =\text { Molded } & \\ \text { Specimen Age } & =28 & \text { DAYS } \\ \text { Specimen Abnormailities } & =\text { None } & \\ \text { Cure } & =\text { Moist Room } \\ \text { Width } & =6 & \text { in } \\ \text { Depth } & =6 & \text { in } \\ \text { Span Length } & =18 & \text { in } \\ \mathrm{O}^{\prime} & =0.0086 \quad \text { in }\end{array}$




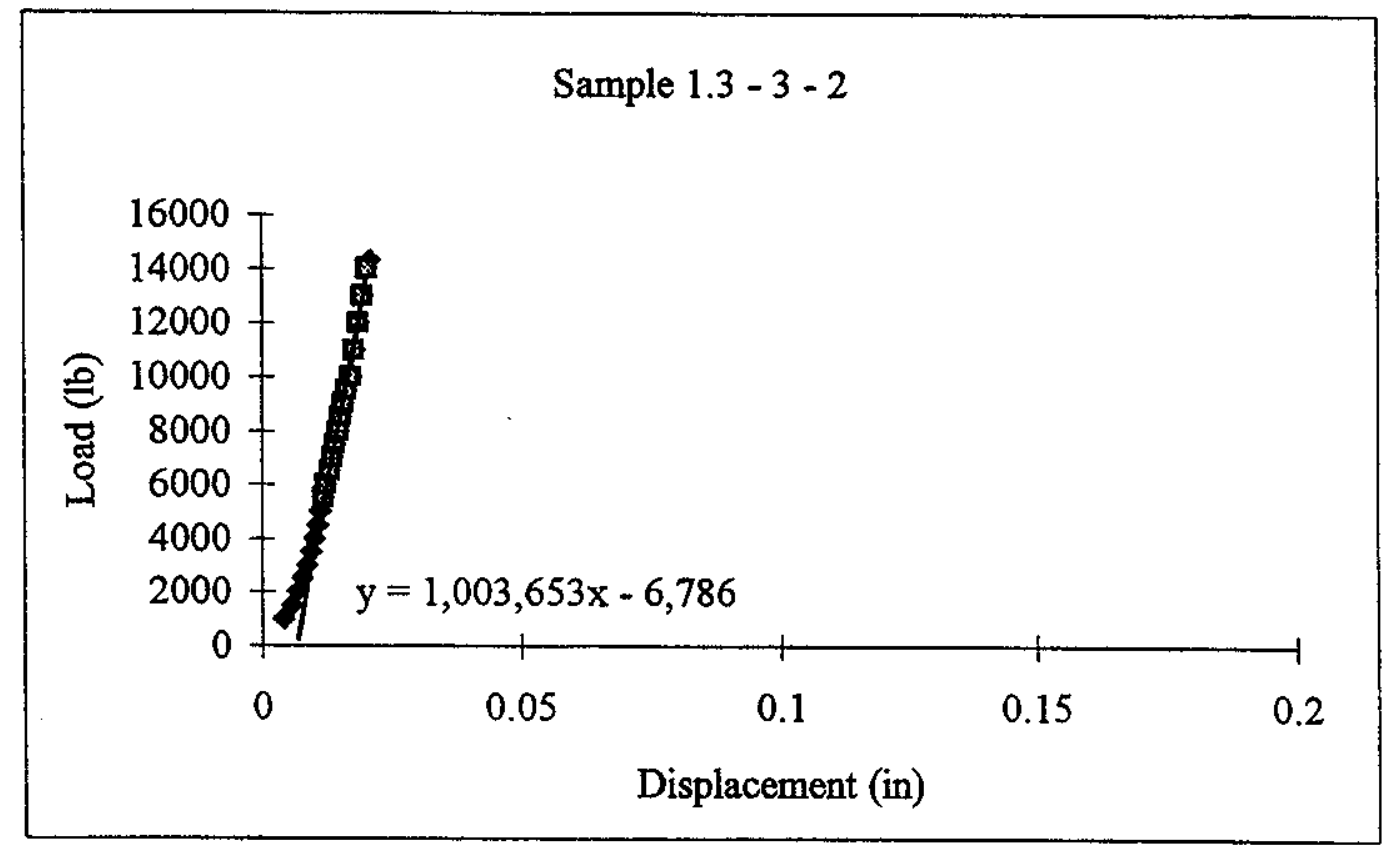

Figure E34: Load Deflection Curve for Specimen $1.3-3-2$

Table E34: Load Deflection Data for Specimen 1.3 - 3 - 2

\begin{tabular}{|c|c|}
\hline $\begin{aligned} \text { First Crack Load } & =14,300 \\
\text { Midspan First Crack Deflection } & =0.0142\end{aligned}$ & $\begin{array}{l}\text { lbs } \\
\text { in }\end{array}$ \\
\hline $\begin{aligned} \text { Modulus of Rupture } & =1191.67 \\
\text { First Crack Toughness } & =101.53\end{aligned}$ & $\begin{array}{l}\text { psi } \\
\text { lb-in }\end{array}$ \\
\hline
\end{tabular}

Specimen Type $=$ Molded

Specimen Age $=28 \quad$ days

Specimen Abnormailities $=$ None

Cure $=$ Moist Room

Width $=6 \quad$ in

Depth $=6 \quad$ in

Span Length $=18$ in

$\mathrm{O}^{\prime}=0.0068$ in 


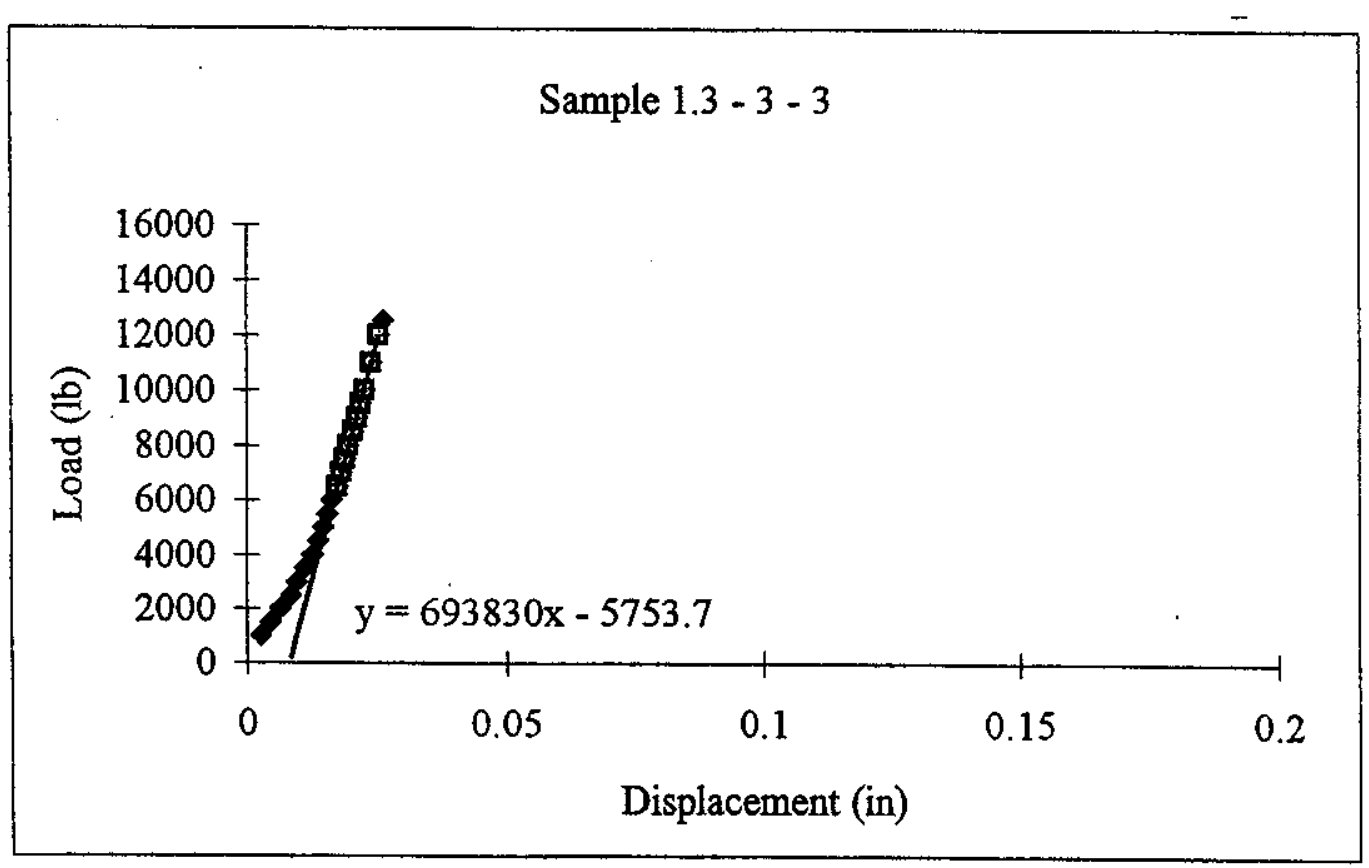

Figure E35: Load Deflection Curve for Specimen $1.3-3-3$

Table E35: Load Deflection Data for Specimen 1.3 - 3 - 3

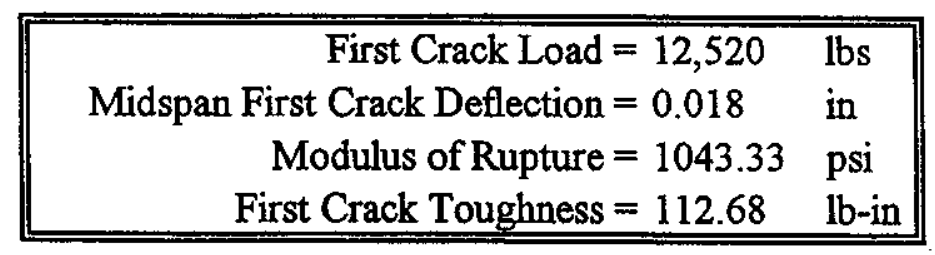

Specimen Type $=$ Molded

Specimen Age $=28 \quad$ days

Specimen Abnormailities $=$ None

Cure $=$ Moist Room

Width $=6$ in

Depth $=6$ in

Span Length $=, 18$ in

$\mathrm{O}^{\prime}=0.0083$ in 


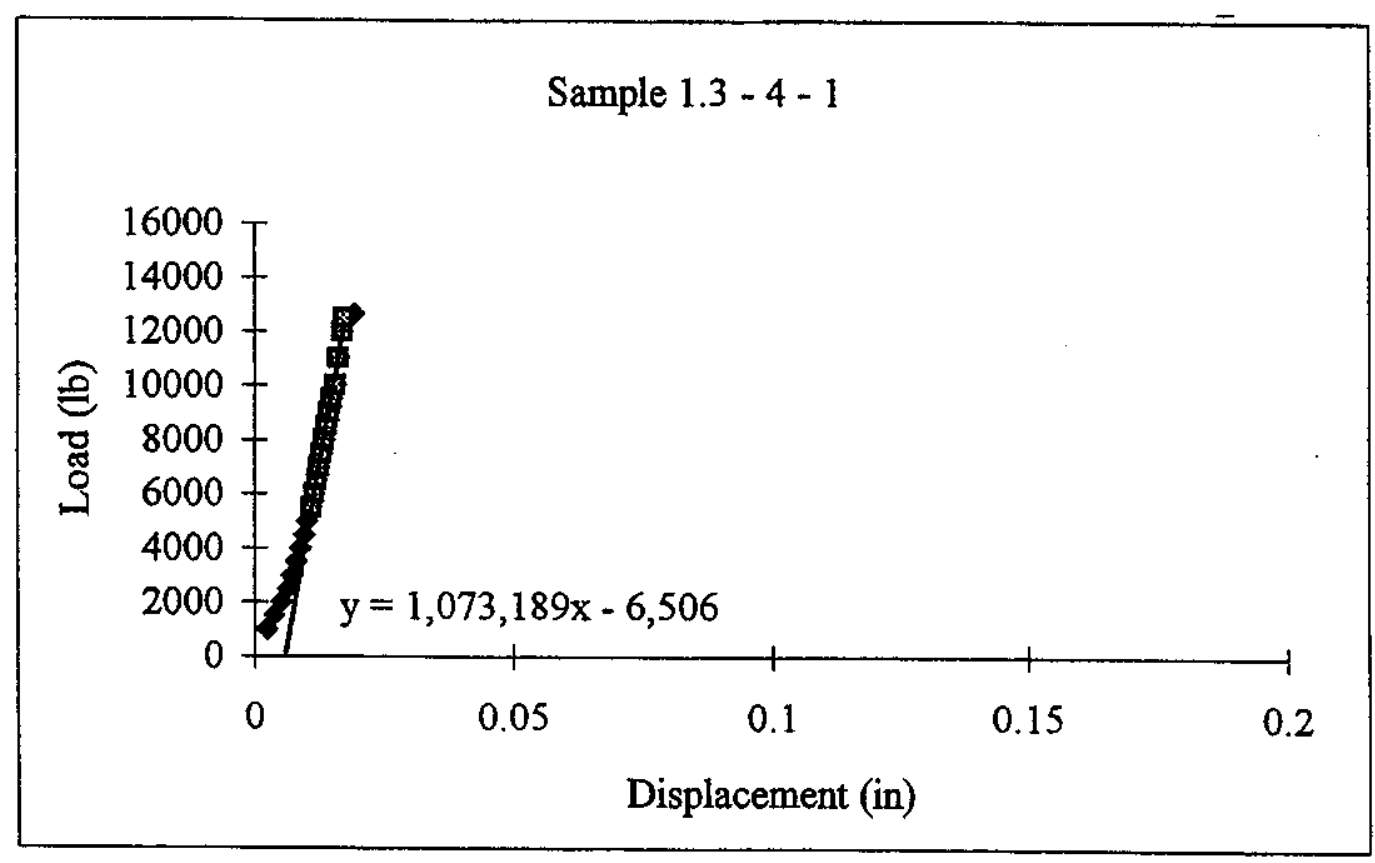

Figure E36: Load Deflection Curve for Specimen 1.3 - 4 - 1

Table E36: Load Deflection Data for Specimen 1.3 - 4 - 1

\begin{tabular}{|c|c|}
\hline First Crack Load $=12,650$ & lbs \\
\hline Midspan First Crack Deflection $=0.0127$ & in \\
\hline Modulus of Rupture $=1054.17$ & psi \\
\hline First Crack Toughness $=80.33$ & lb-in \\
\hline
\end{tabular}

\section{Specimen Type $=$ Molded}

Specimen Age $=28 \quad$ days

Specimen Abnormailities $=$ None

Cure $=$ Moist Room

Width $=6 \quad$ in

Depth $=6$ in

Span Length $=18$ in

$\mathrm{O}^{\prime}=0.0065$ in 


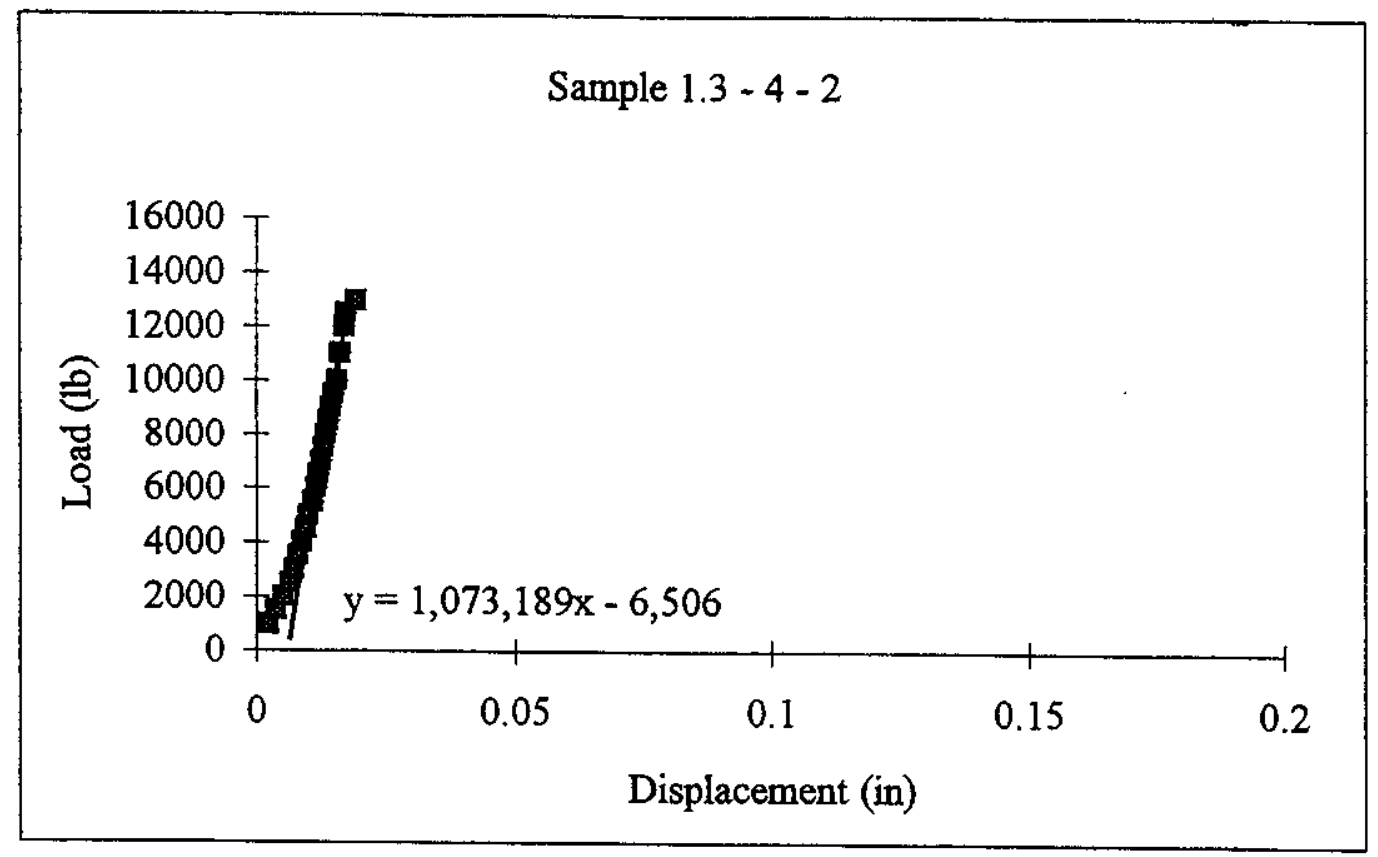

Figure E37: Load Deflection Curve for Specimen 1.3 - 4 - 2

Table E37: Load Deflection Data for Specimen 1.3 - 4 - 2

\begin{tabular}{|c|c|}
\hline First Crack Load $=12,940$ & lbs \\
\hline Midspan First Crack Deflection $=0.0129$ & in \\
\hline Modulus of Rupture $=1078.33$ & psi \\
\hline First Crack Toughness $=83.46$ & $\mathrm{lb}$-in \\
\hline
\end{tabular}

Specimen Type $=$ Molded

Specimen Age $=28 \quad$ days

Specimen Abnormailities = None

Cure $=$ Moist Room

Width $=6$ in

Depth $=6$ in

Span Length $=18$ in

$\mathrm{O}^{\prime}=0.0065$ in 


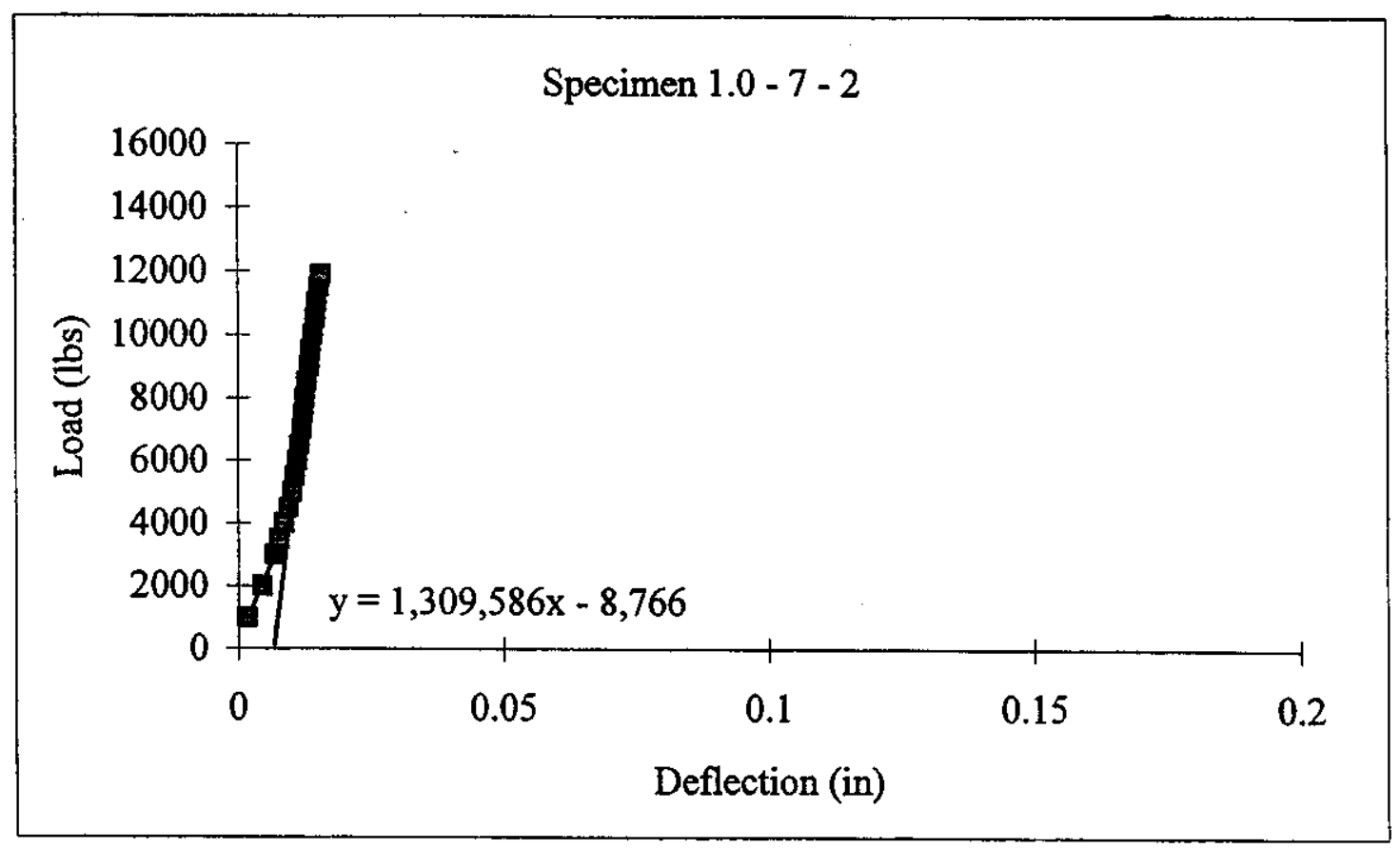

Figure E32: Load Deflection Curve for Specimen 1.0 - 7 - 2

Table E32: Load Deflection Data for Specimen 1.0 - 7 - 2

\begin{tabular}{|c|c|}
\hline $\begin{aligned} \text { First Crack Load } & =11,880 \\
\text { Midspan First Crack Deflection } & =0.0091 \\
\text { Modulus of Rupture } & =990 \\
\text { First Crack Toughness } & =54.05\end{aligned}$ & $\begin{array}{l}\mathrm{lbs} \\
\text { in } \\
\text { psi } \\
\mathrm{lb} \text {-in }\end{array}$ \\
\hline
\end{tabular}

Specimen Type $=$ Molded

$$
\text { Specimen Age }=28 \quad \text { DAYS }
$$

Specimen Abnormailities $=$ None

Cure $=$. Moist Room

Width $=6$ in

Depth $=6$ in

Span Length $=18$ in

$$
\mathrm{O}^{\prime}=0.0067 \text { in }
$$




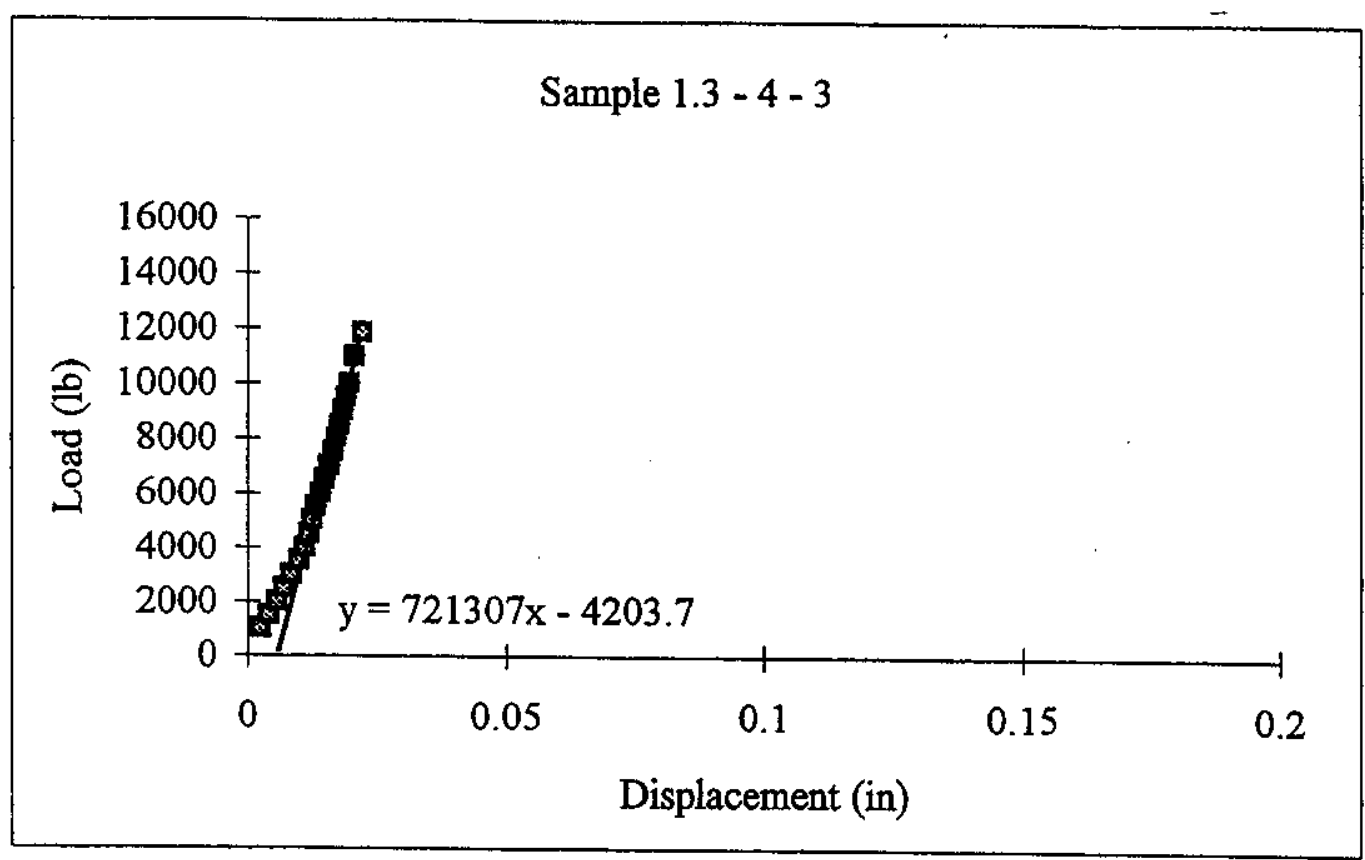

Figure E38: Load Deflection Curve for Specimen 1.3 - 4 - 3

Table E38: Load Deflection Data for Specimen 1.3 - 4 - 3

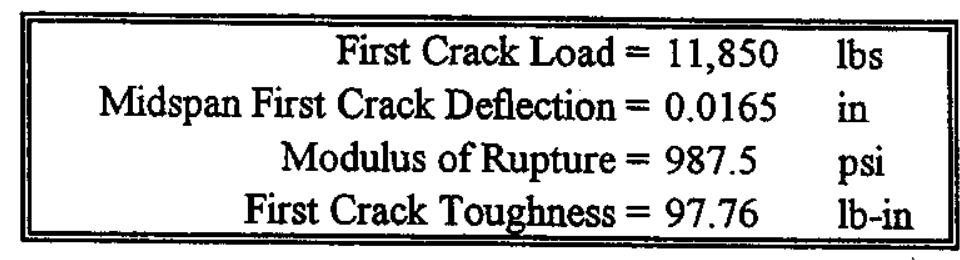

Specimen Type $=$ Molded

Specimen Age $=28 \quad$ days

Specimen Abnormailities $=$ None

Cure $=$ Moist Room

Width $=6$ in

Depth $=6$ in

Span Length $=18$ in

$\mathrm{O}^{\prime}=0.0058$ in 


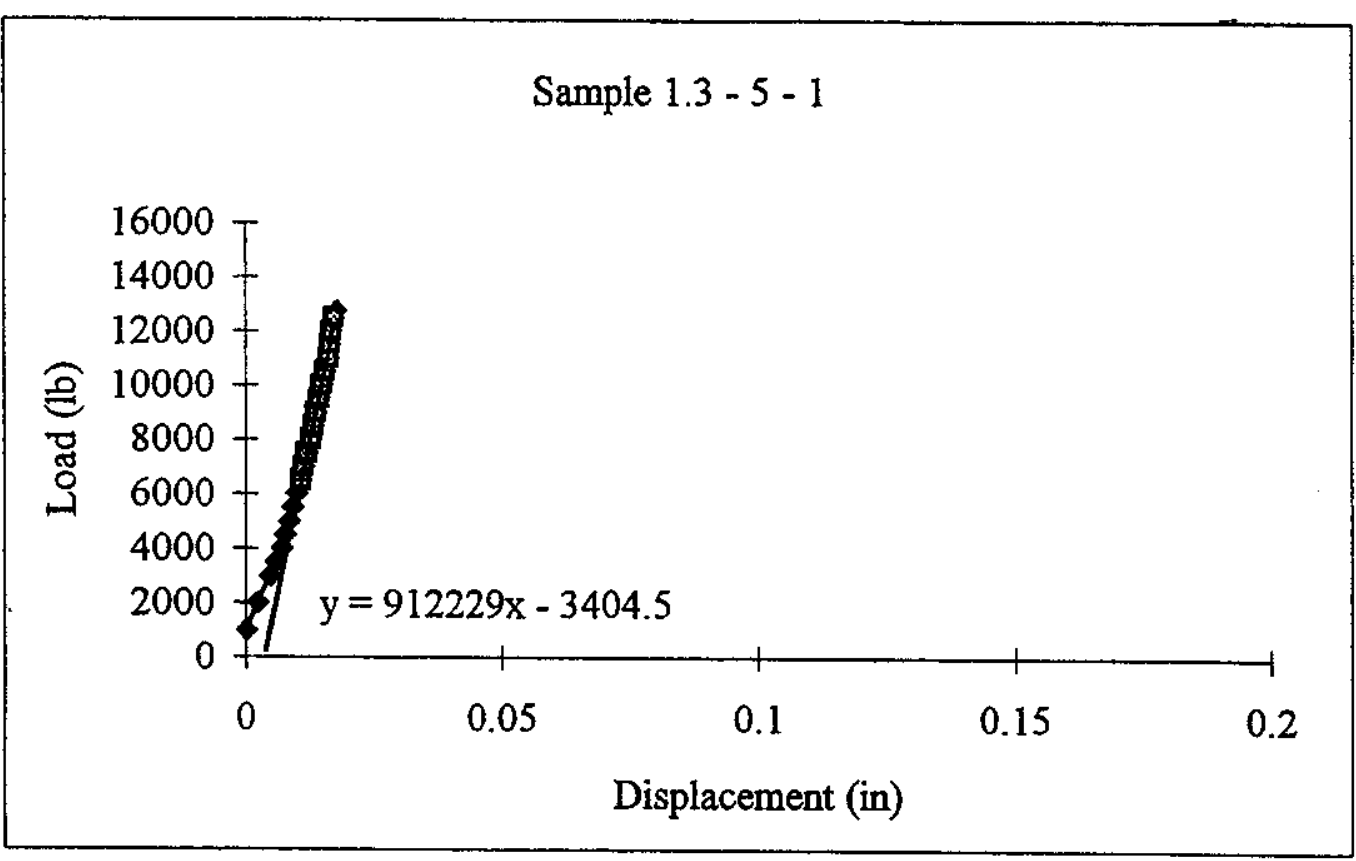

Figure E39: Load Deflection Curve for Specimen 1.3 - 5 - 1

Table E39: Load Deflection Data for Specimen 1.3 - 5 - 1

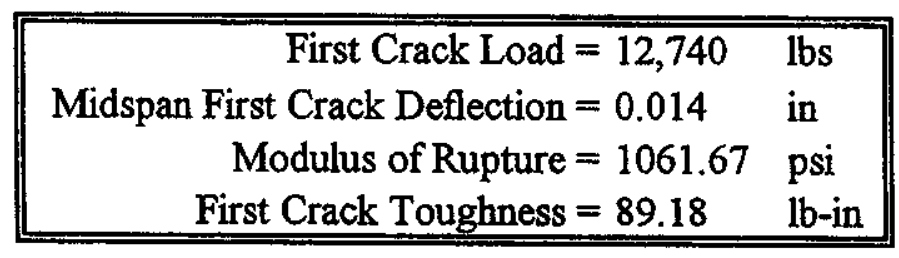

Specimen Type $=$ Molded

$$
\text { Specimen Age }=28 \quad \text { days }
$$

Specimen Abnormailities $=$ None

$$
\text { Cure }=\text { Moist Room }
$$

Width $=6 \quad$ in

Depth $=6 \quad$ in

Span Length $=18 \quad$ in

$\mathrm{O}^{\prime}=0.0037$ in 


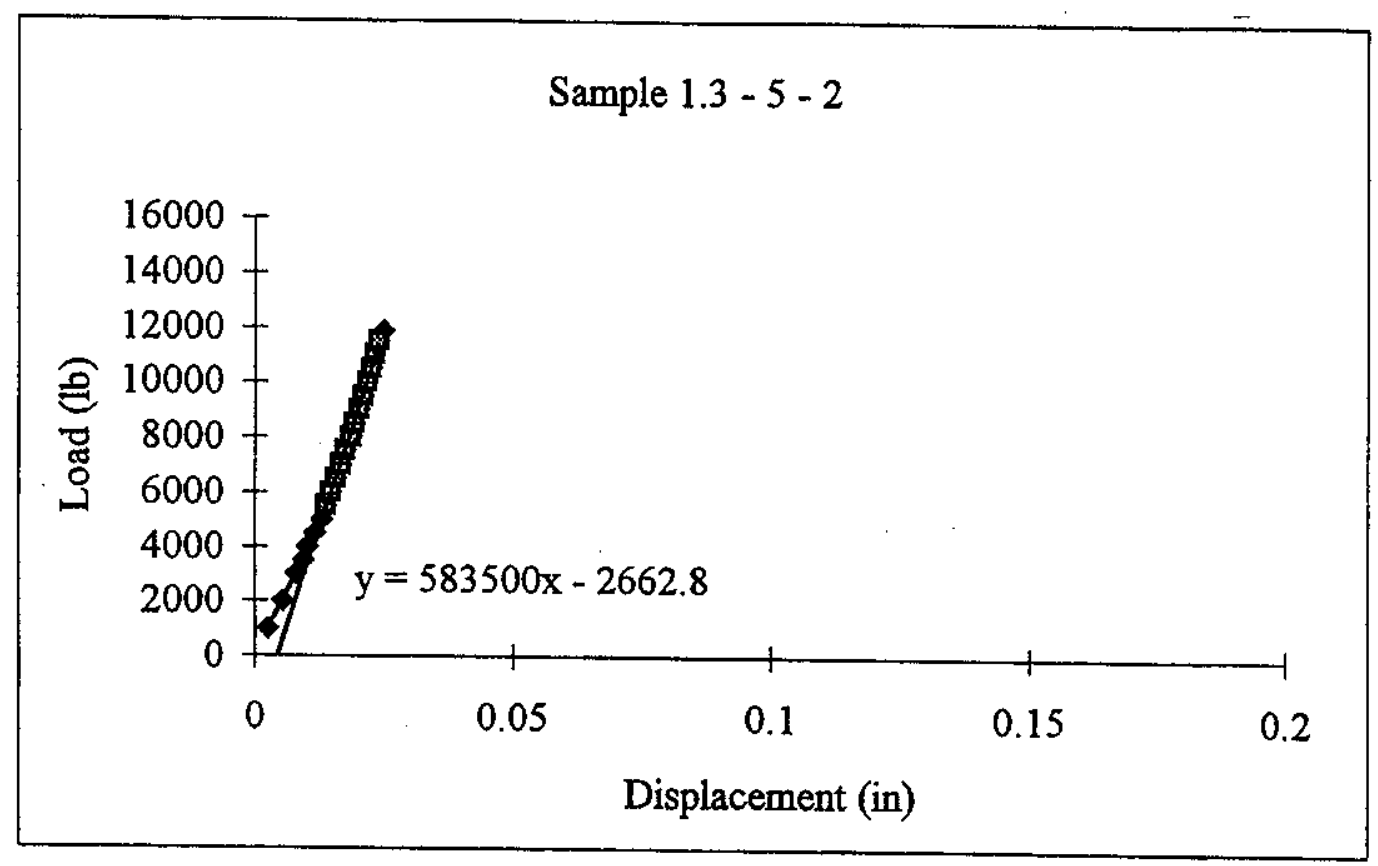

Figure E40: Load Deflection Curve for Specimen 1.3 - 5 - 2

Table E40: Load Deflection Data for Specimen 1.3 - 5 - 2

\begin{tabular}{rll|}
\hline First Crack Load & $=11,850$ & lbs \\
Midspan First Crack Deflection & $=0.0203$ & in \\
Modulus of Rupture & $=987.5$ & psi \\
First Crack Toughness & $=120.28$ & lb-in \\
\hline
\end{tabular}

Specimen Type $=$ Molded

Specimen Age $=28$ days

Specimen Abnormailities $=$ None

Cure $=$ Moist Room

Width $=6$ in

Depth $=6$ in

Span Length $=18$ in

$\mathrm{O}^{\prime}=0.0046$ in 


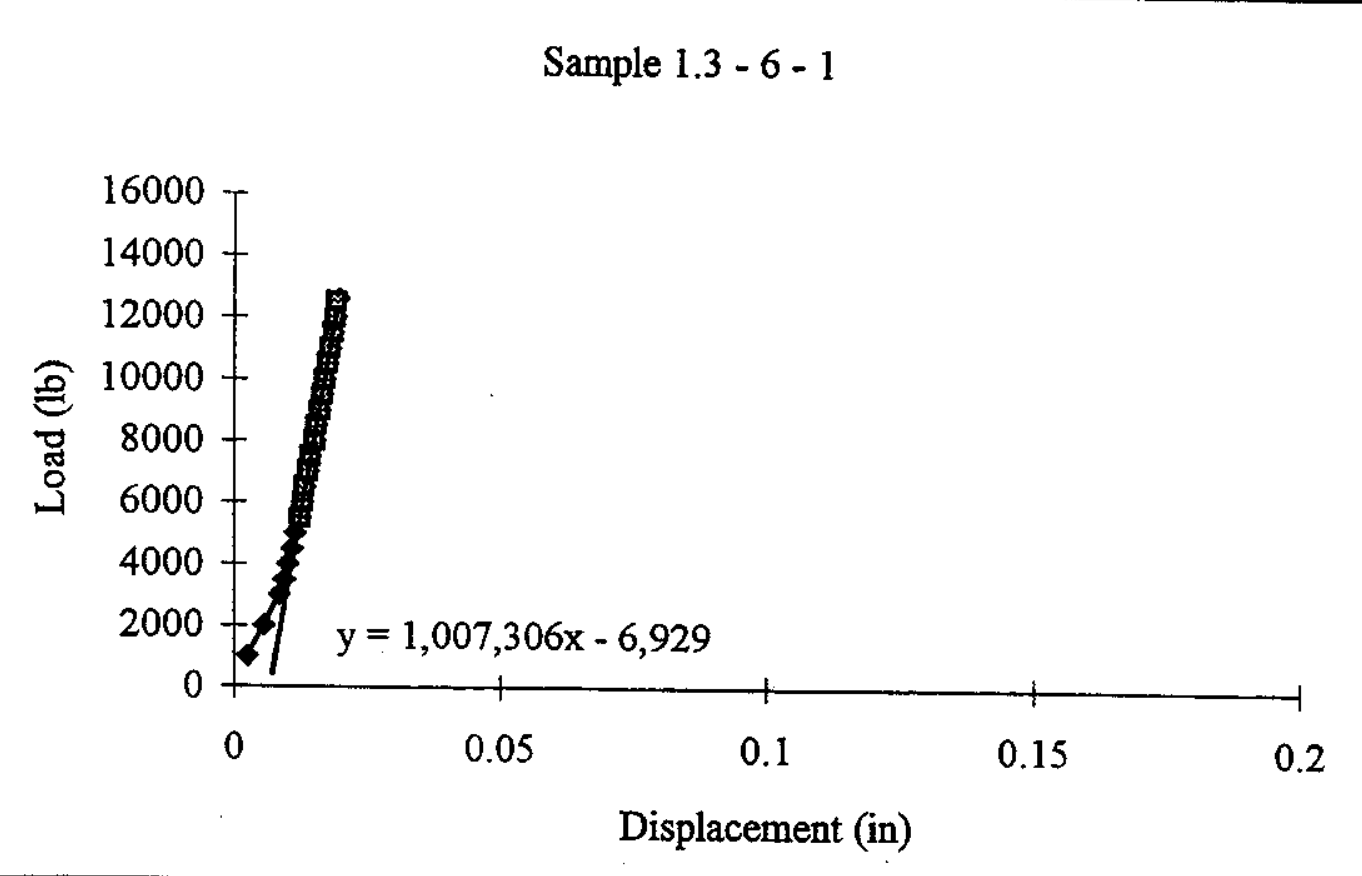

Figure E41: Load Deflection Curve for Specimen 1.3 - 6 - 1

Table E41: Load Deflection Data for Specimen 1.3 - 6 - 1

\begin{tabular}{|c|c|}
\hline First Crack Load $=12,600$ & lbs \\
\hline Midspan First Crack Deflection $=0.0126$ & in \\
\hline Modulus of Rupture $=1050$ & psi \\
\hline First Crack Toughness $=79.38$ & lb-in \\
\hline
\end{tabular}

Specimen Type $=$ Molded

Specimen Age $=28 \quad$ days

Specimen Abnormailities $=$ None

Cure $=$ Moist Room

Width $=6$ in

Depth $=6$ in

Span Length $=18 \quad$ in

$\mathrm{O}^{\prime}=0.0069$ in 


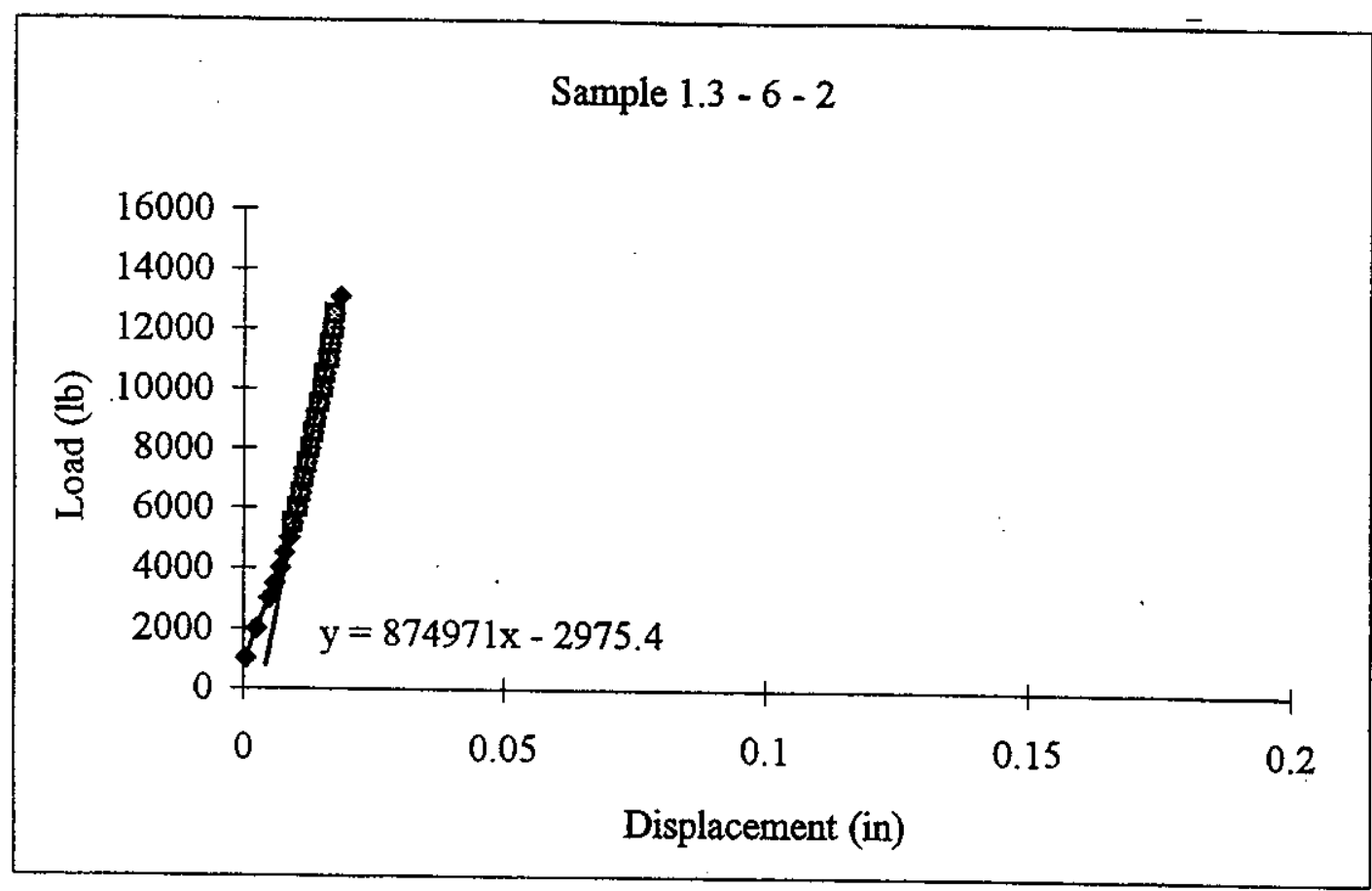

Figure E42: Load Deflection Curve for Specimen 1.3 - 6 - 2

Table E42: Load Deflection Data for Specimen 1.3 - 6 - 2

\begin{tabular}{|c|c|}
\hline $\begin{aligned} \text { First Crack Load } & =13,080 \\
\text { Midspan First Crack Deflection } & =0.015 \\
\text { Modulus of Rupture } & =1090 \\
\text { First Crack Toughness } & =98.10\end{aligned}$ & $\begin{array}{l}\text { lbs } \\
\text { in } \\
\text { psi } \\
\text { lb-in }\end{array}$ \\
\hline
\end{tabular}

$\begin{array}{rlr}\text { Specimen Type } & =\text { Molded } \\ \text { Specimen Age } & =28 & \text { days } \\ \text { Specimen Abnormailities } & =\text { None } & \\ \text { Cure } & =\text { Moist Room } \\ \text { Width } & =6 & \text { in } \\ \text { Depth } & =6 & \text { in } \\ \text { Span Length } & =18 & \text { in } \\ O^{\prime} & =0.0034 & \text { in }\end{array}$




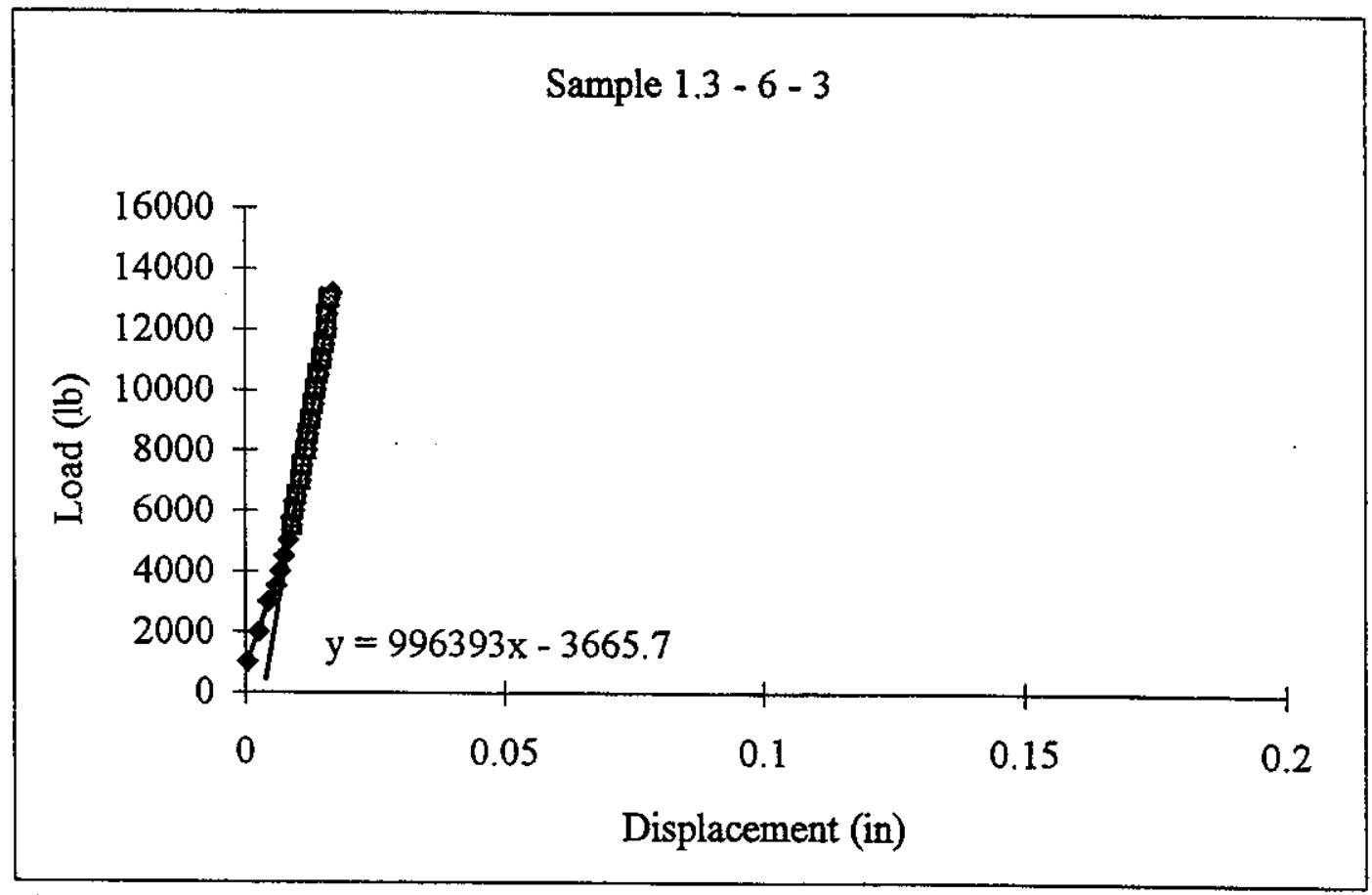

Figure E43: Load Deflection Curve for Specimen 1.3 - 6 - 3

Table E43: Load Deflection Data for Specimen 1.3 - 6 - 3

\begin{tabular}{|c|c|}
\hline $\begin{aligned} \text { First Crack Load } & =13,200 \\
\text { Midspan First Crack Deflection } & =0.0132 \\
\text { Modulus of Rupture } & =1100 \\
\text { First Crack Toughness } & =87.12\end{aligned}$ & $\begin{array}{l}\text { lbs } \\
\text { in } \\
\text { psi } \\
\text { lb-in }\end{array}$ \\
\hline
\end{tabular}

\begin{tabular}{|c|c|}
\hline $\begin{aligned} \text { Specimen Type } & =\text { Molded } \\
\text { Specimen Age } & =28 \\
\text { Specimen Abnormailities } & =\text { None }\end{aligned}$ & day \\
\hline & \\
\hline Cure $=$ Moist $R$ & om \\
\hline Width $=6$ & in \\
\hline Depth $=6$ & . \\
\hline Span Length $=18$ & $w$ \\
\hline $\mathrm{O}^{\prime}=0.0037$ & in \\
\hline
\end{tabular}




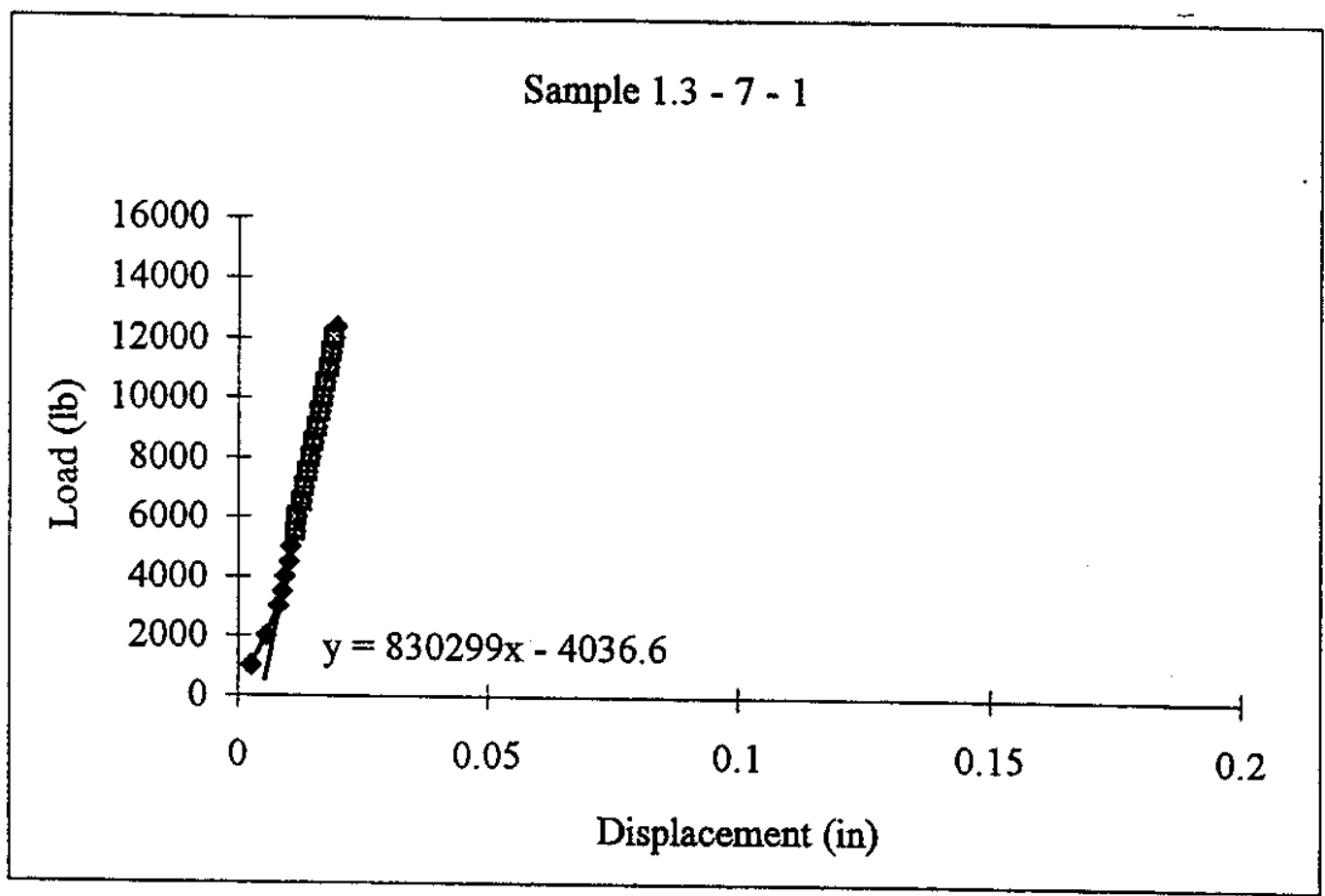

Figure E44: Load Deflection Curve for Specimen 1.3 - 7 - 1

Table E44: Load Deflection Data for Specimen 1.3 - 7 - 1

\begin{tabular}{|c|c|}
\hline First Crack Load $=12,360$ & lbs \\
\hline Midspan First Crack Deflection $=0.0148$ & in \\
\hline Modulus of Rupture $=1030$ & psi \\
\hline First Crack Toughness $=91.46$ & lb-in \\
\hline
\end{tabular}

Specimen Type $=$ Molded

Specimen Age $=28 \quad$ days

Specimen Abnormailities $=$ None

Cure $=$ Moist Room

Width $=6$ in

Depth $=6$ in

Span Length $=18$ in

$\mathrm{O}^{\prime}=0.0049$ in 


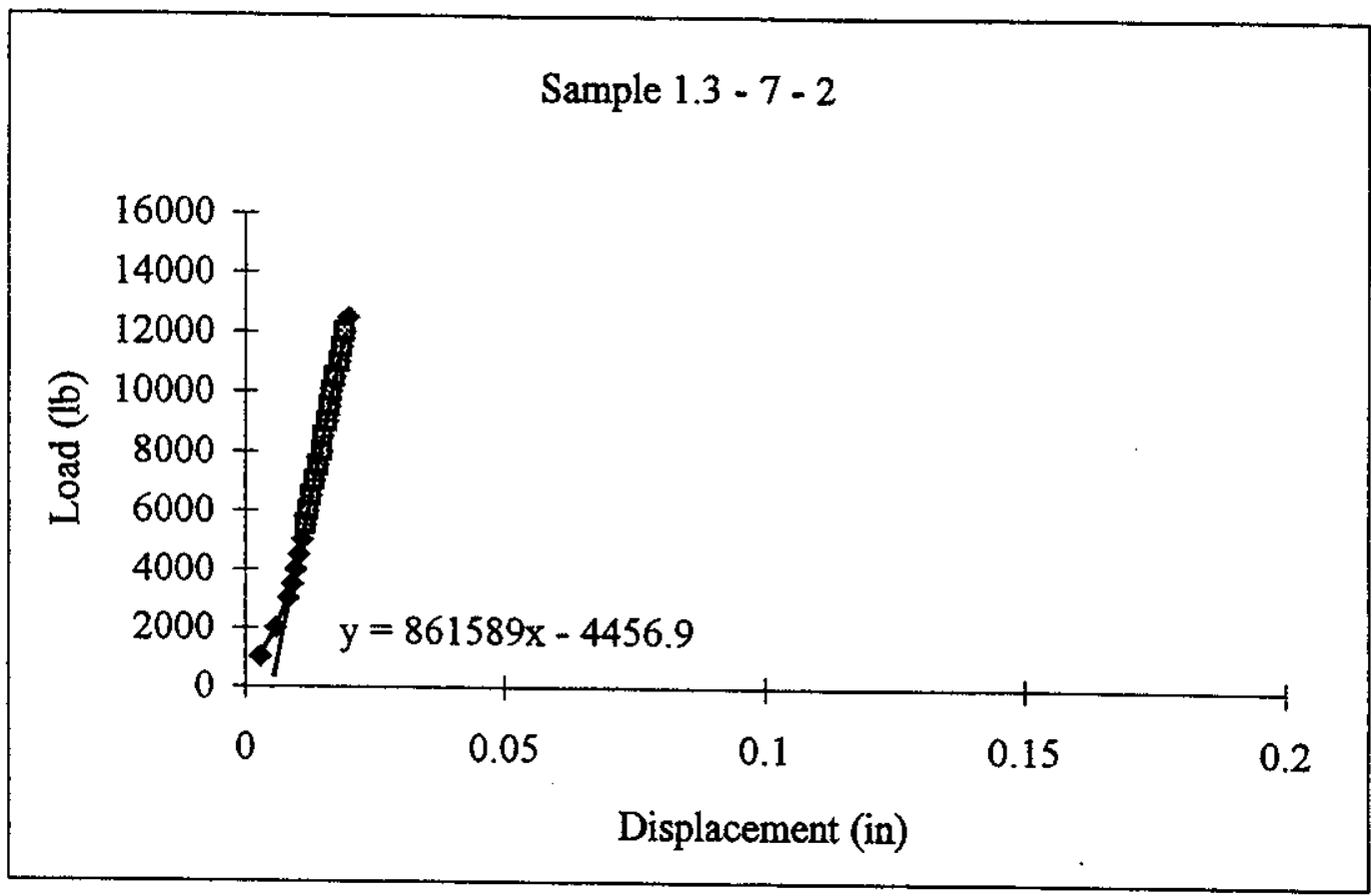

Figure E45: Load Deflection Curve for Specimen 1.3 - 7 - 2

Table E45: Load Deflection Data for Specimen 1.3 - 7 - 2

\begin{tabular}{|c|c|}
\hline First Crack Load $=12,480$ & lbs \\
\hline Midspan First Crack Deflection $=0.0145$ & in \\
\hline Modulus of Rupture $=1040$ & psi \\
\hline First Crack Toughness $=90.48$ & lb-in \\
\hline
\end{tabular}

Specimen Type $=$ Molded

Specimen Age $=28 \quad$ days

Specimen Abnormailities $=$ None

Cure $=$ Moist Room

Width $=6 \quad$ in

Depth $=6$ in

Span Length $=18 \quad$ in

$\mathrm{O}^{\prime}=0.0052$ in 


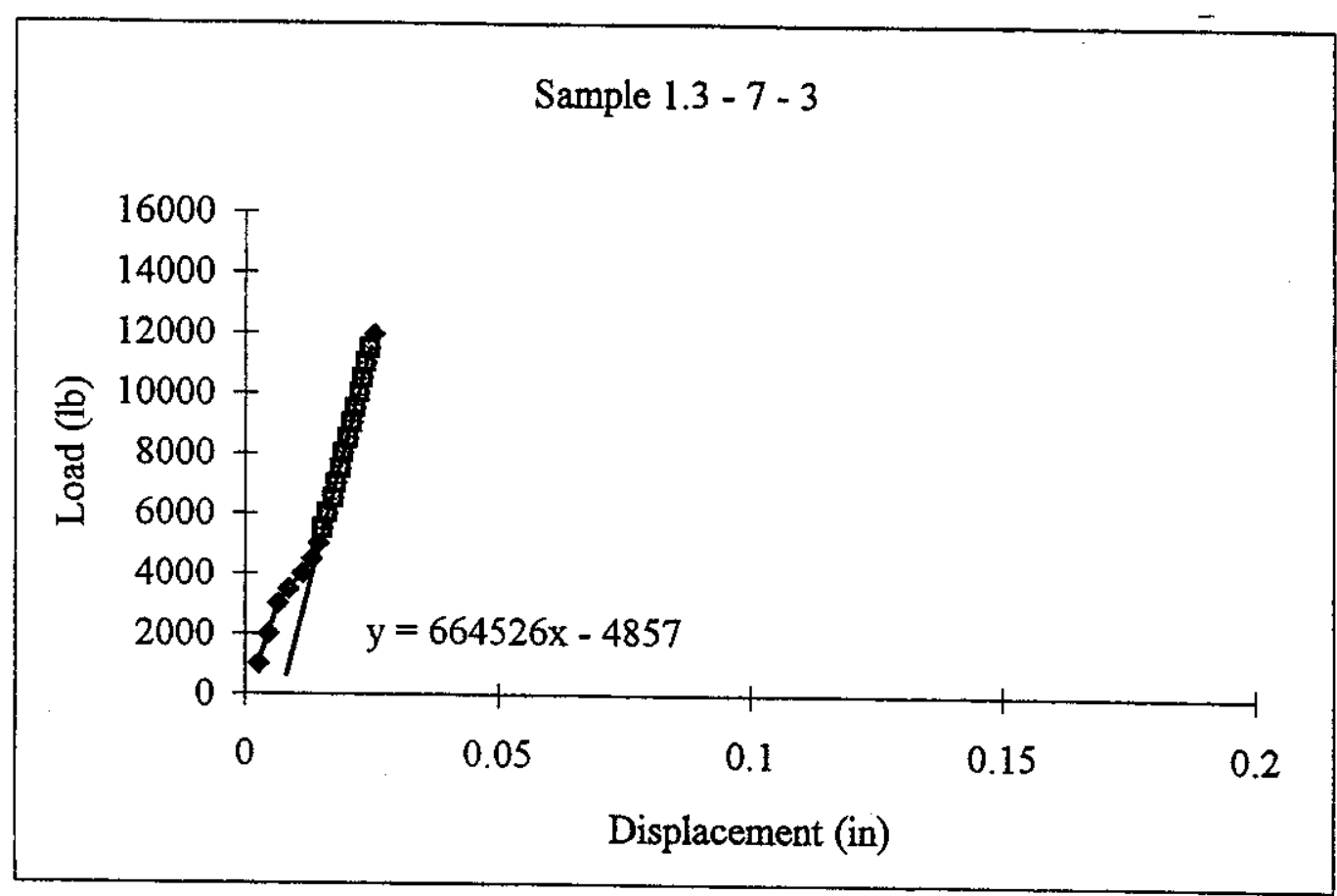

Figure E46: Load Deflection Curve for Specimen 1.3 - 7 - 3

Table E46: Load Deflection Data for Specimen 1.3 - 7 - 3

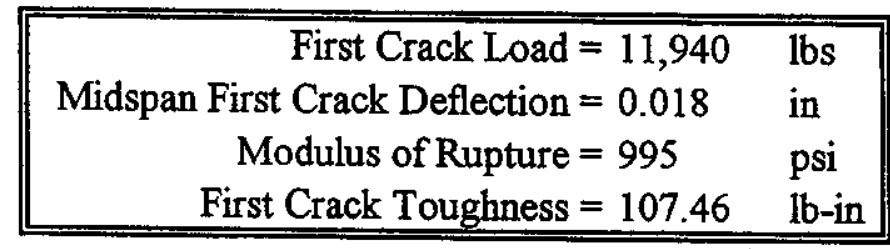

$$
\begin{aligned}
& \text { Specimen Type }=\text { Molded } \\
& \text { Specimen Age }=28 \text { days } \\
& \text { Specimen Abnormailities }=\text { None } \\
& \text { Cure }=\text { Moist Room } \\
& \text { Width }=6 \text { in } \\
& \text { Depth }=6 \quad \text { in } \\
& \text { Span Length }=18 \text { in } \\
& \mathrm{O}^{\prime}=0.0073 \text { in }
\end{aligned}
$$




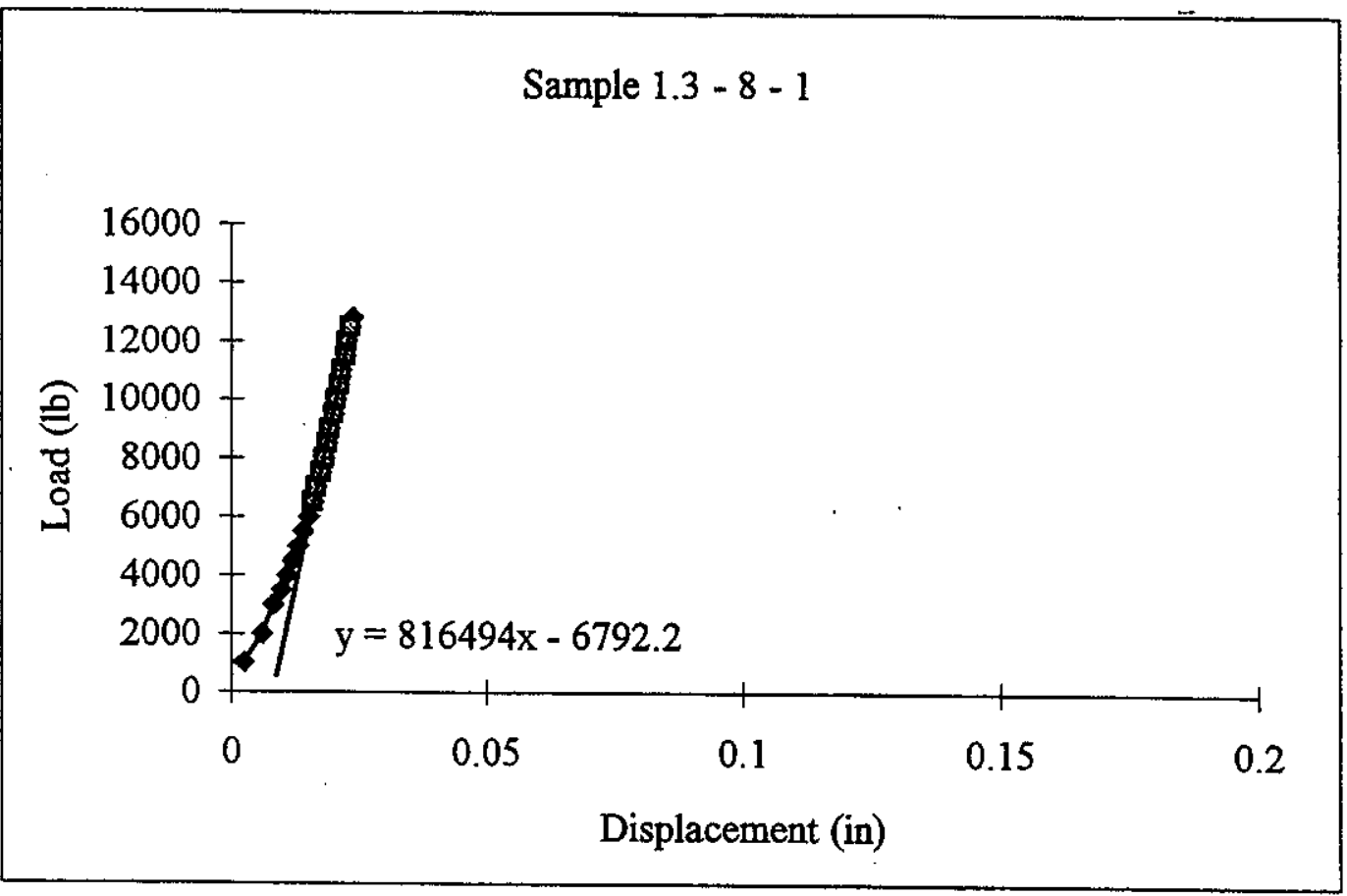

Figure E47: Load Deflection Curve for Specimen 1.3-8 - 1

Table E47: Load Deflection Data for Specimen 1.3 - 8 - 1

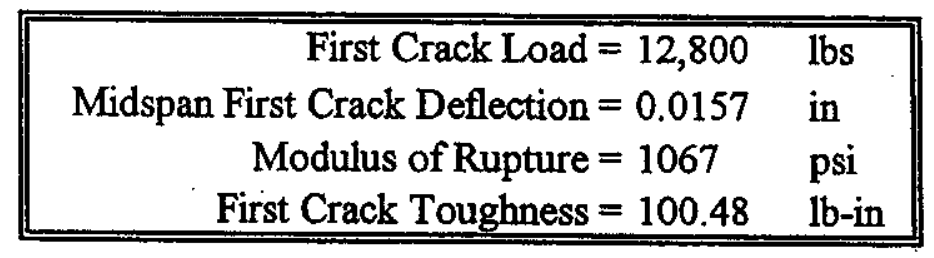

Specimen Type $=$ Molded

Specimen Age $=28 \quad$ days

Specimen Abnormailities $=$ None

Cure $=$ Moist Room

Width $=6$ in

Depth $=6 \quad$ in

Span Length $=18$ in

$\mathrm{O}^{\prime}=0.0083$ in 


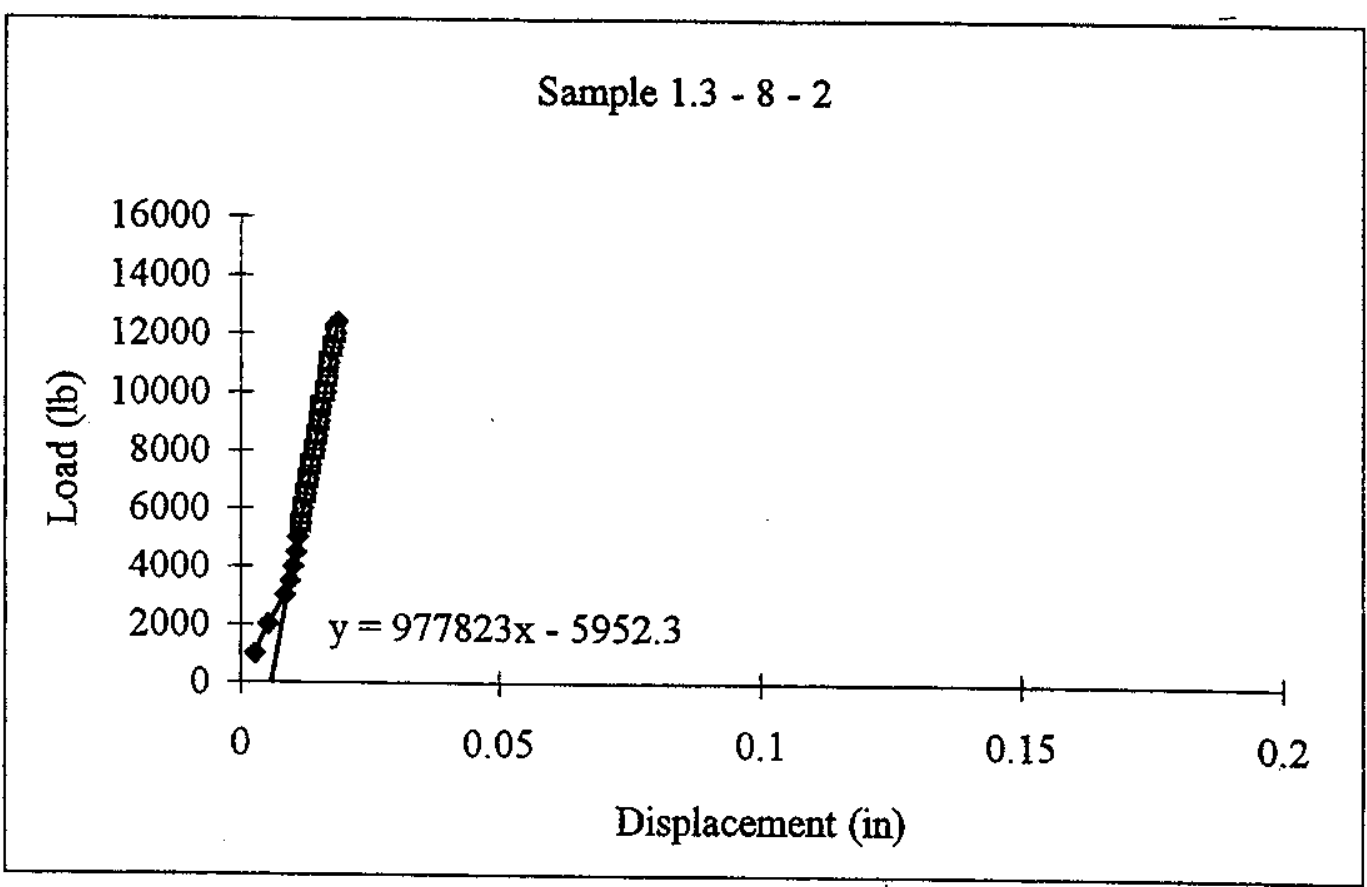

Figure E48: Load Deflection Curve for Specimen 1.3 - 8 - 2

Table E48: Load Deflection Data for Specimen 1.3 - 8 - 2

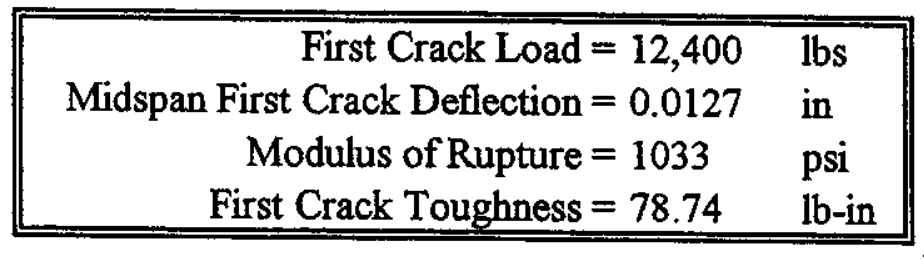

Specimen Type $=$ Molded

Specimen Age $=28 \quad$ days

Specimen Abnormailities $=$ None

Cure $=$ Moist Room

Width $=6 \quad$ in

Depth $=6$ in

Span Length $=18 \quad$ in

$O^{\prime}=0.0061$ in 


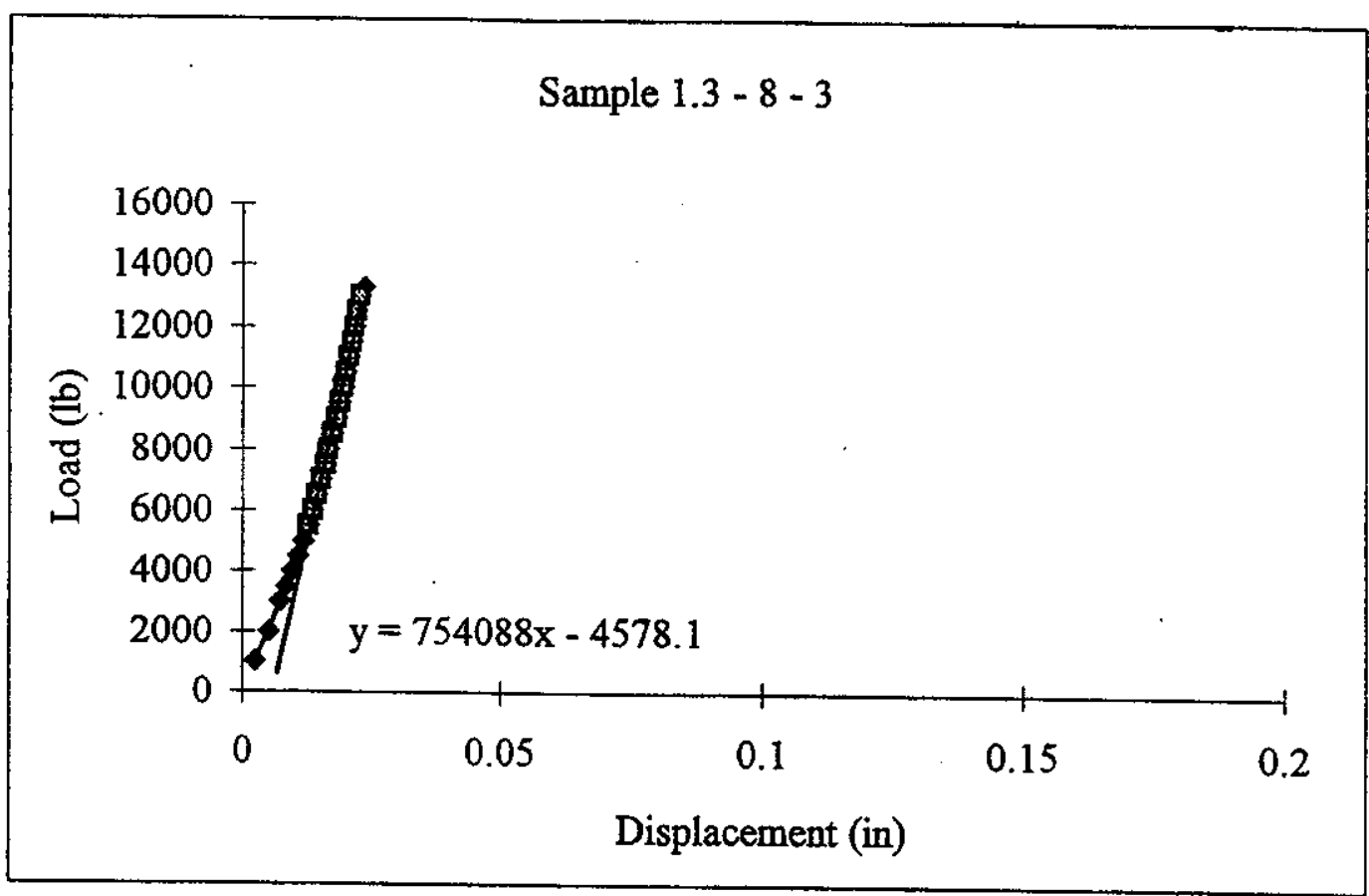

Figure E49: Load Deflection Curve for Specimen 1.3 - 8 - 3

Table E49: Load Deflection Data for Specimen 1.3 - 8 - 3

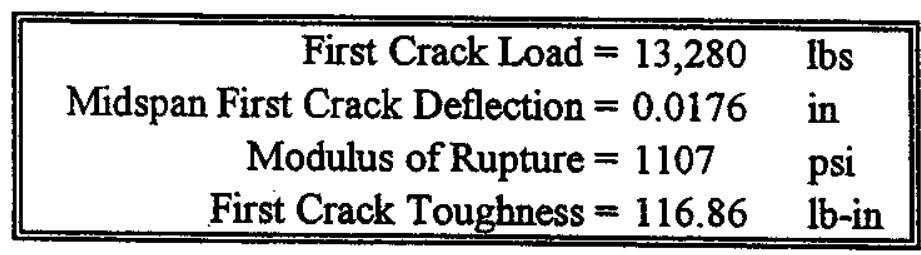

Specimen Type $=$ Molded

$$
\text { Specimen Age }=28 \quad \text { days }
$$

Specimen Abnormailities $=$ None

Cure $=$ Moist Room

Width $=6 \quad$ in

Depth $=6$ in

Span Length $=18$ in

$$
\mathrm{O}^{\prime}=0.0061 \quad \text { in }
$$




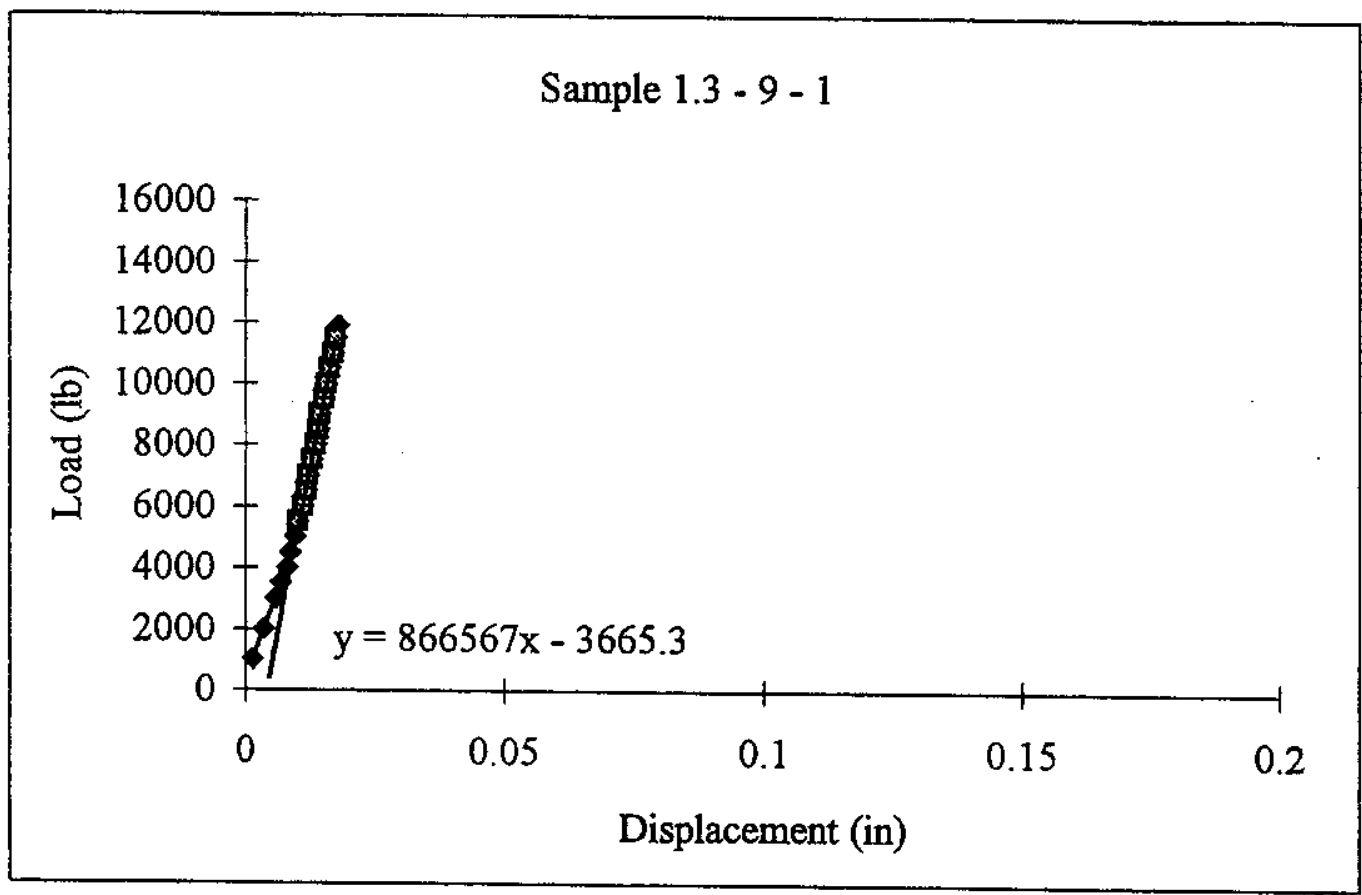

Figure E50: Load Deflection Curve for Specimen 1.3 - 9 - 1

Table E50: Load Deflection Data for Specimen 1.3 - 9 - 1

\begin{tabular}{|c|c|}
\hline \multicolumn{2}{|l|}{ First Crack Load $=11,880$} \\
\hline Midspan First Crack Deflection $=0.0137$ & in \\
\hline Modulus of Rupture $=990$ & psi \\
\hline First Crack Toughness $=81.38$ & lb-in \\
\hline
\end{tabular}

Specimen Type $=$ Molded

Specimen Age $=28 \quad$ days

Specimen Abnormailities $=$ None

Cure $=$ Moist Room

Width $=6 \quad$ in

Depth $=6$ in

Span Length $=18 \quad$ in

$\mathrm{O}^{\prime}=0.0042$ in 


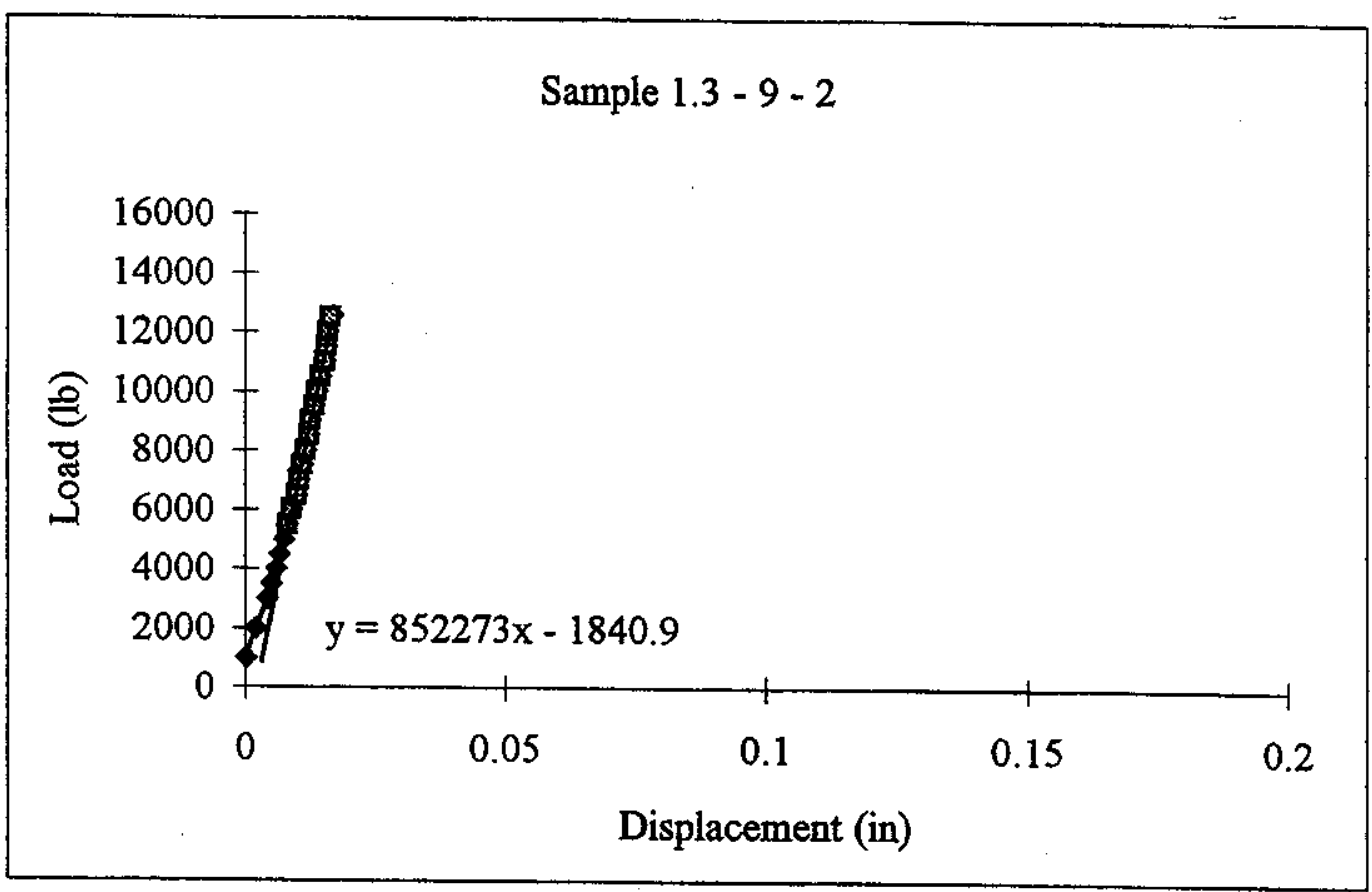

Figure E51: Load Deflection Curve for Specimen 1.3 - 9-2

Table E51: Load Deflection Data for Specimen 1.3 - 9 - 2

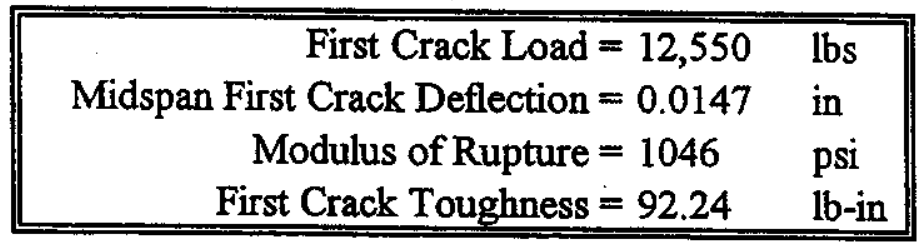

Specimen Type $=$ Molded

Specimen Age $=28 \quad$ days

Specimen Abnormailities $=$ None

Cure $=$ Moist Room

Width $=6$ in

Depth $=6$ in

Span Length $=18 \quad$ in

$\mathrm{O}^{\prime}=0.0022$ in 


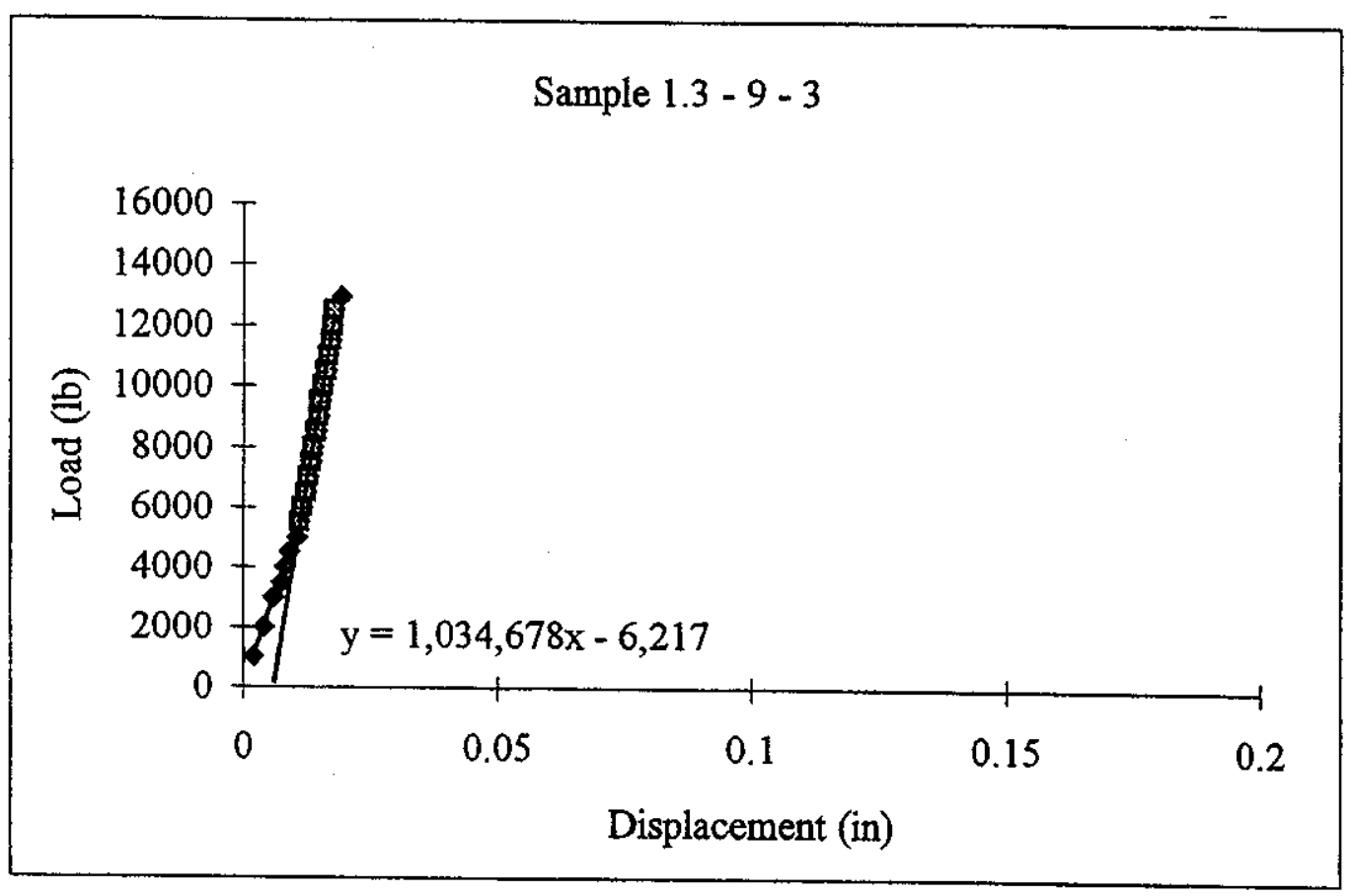

Figure E52: Load Deflection Curve for Specimen 1.3 - 9 - 3

Table E52: Load Deflection Data for Specimen 1.3 - 9 - 3

\begin{tabular}{|c|c|}
\hline First Crack Load $=12,940$ & Ibs \\
\hline Midspan First Crack Deflection $=0.013$ & in \\
\hline Modulus of Rupture $=1078$ & psi \\
\hline First Crack Toughness $=84.11$ & lb-in \\
\hline
\end{tabular}

$$
\begin{array}{rlrl}
\text { Specimen Type } & =\text { Molded } & \\
\text { Specimen Age } & =28 & \text { days } \\
\text { Specimen Abnormailities } & =\text { None } & \\
\text { Cure } & =\text { Moist Room } \\
\text { Width } & =6 & \text { in } \\
\text { Depth } & =6 & \text { in } \\
\text { Span Length } & =18 & \text { in } \\
O^{\prime} & =0.0062 & \text { in }
\end{array}
$$




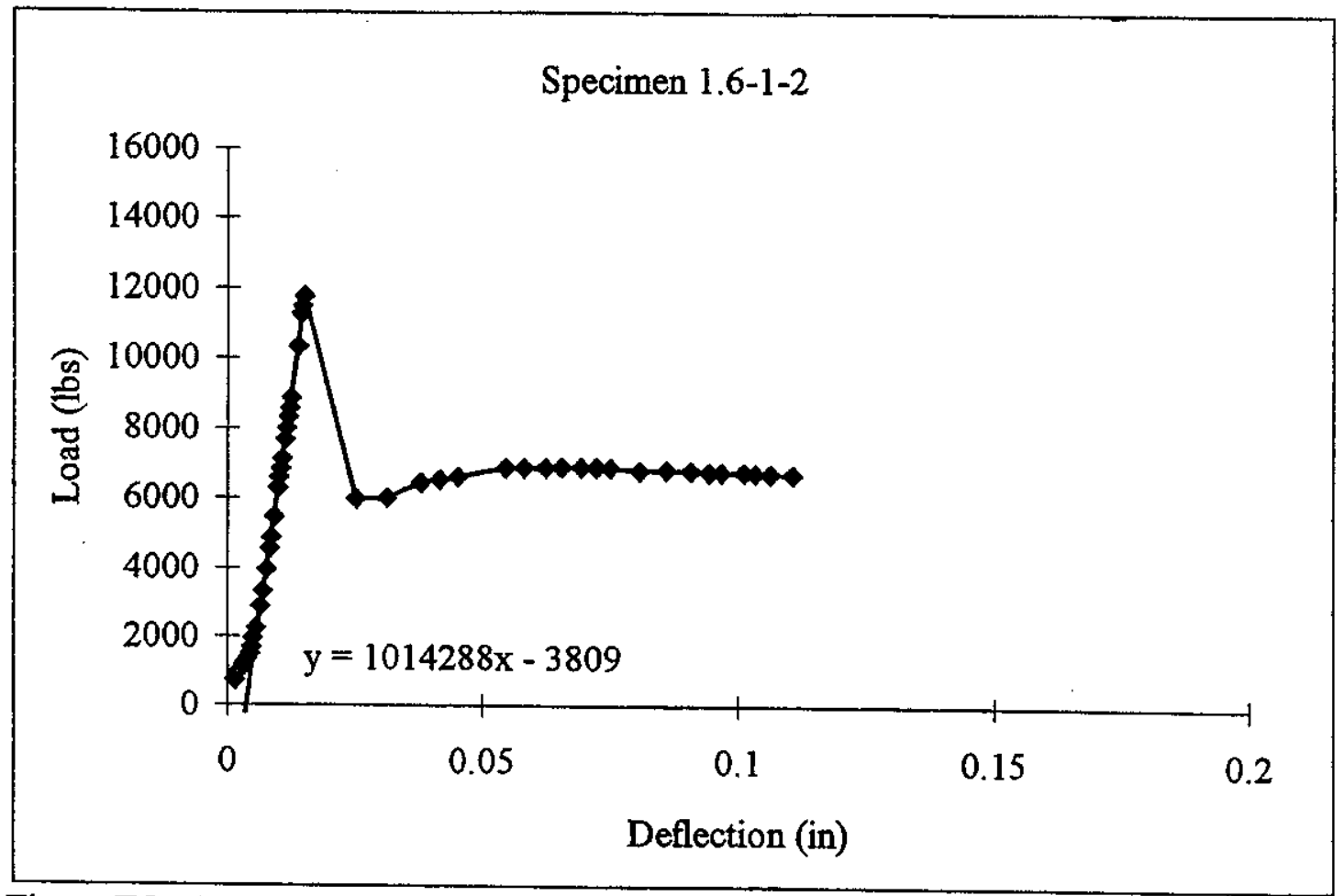

Figure E53: Load Deflection Curve for Specimen 1.6 - 1 - 2

Table E53: Load Deflection Data for Specimen 1.6 - 1 - 2

\begin{tabular}{|c|c|}
\hline $\begin{aligned} \text { First Crack Load } & =11,740 \\
\text { Midspan First Crack Deflection } & =0.0114 \\
\text { Modulus of Rupture } & =978.33 \\
\text { First Crack Toughness } & =66.92\end{aligned}$ & $\begin{array}{l}\mathrm{lbs} \\
\text { in } \\
\mathrm{psi} \\
\mathrm{lb} \text {-in }\end{array}$ \\
\hline
\end{tabular}

Specimen Type $=$ Molded

Specimen Age $=$

Specimen Abnormailities $=$ None

$$
\begin{aligned}
\text { Cure } & =\text { Moist Room } \\
\text { Width } & =6 \quad \text { in }
\end{aligned}
$$

Depth $=6$ in

Span Length $=18$ in

$$
\mathrm{O}^{\prime}=0.0038 \text { in }
$$




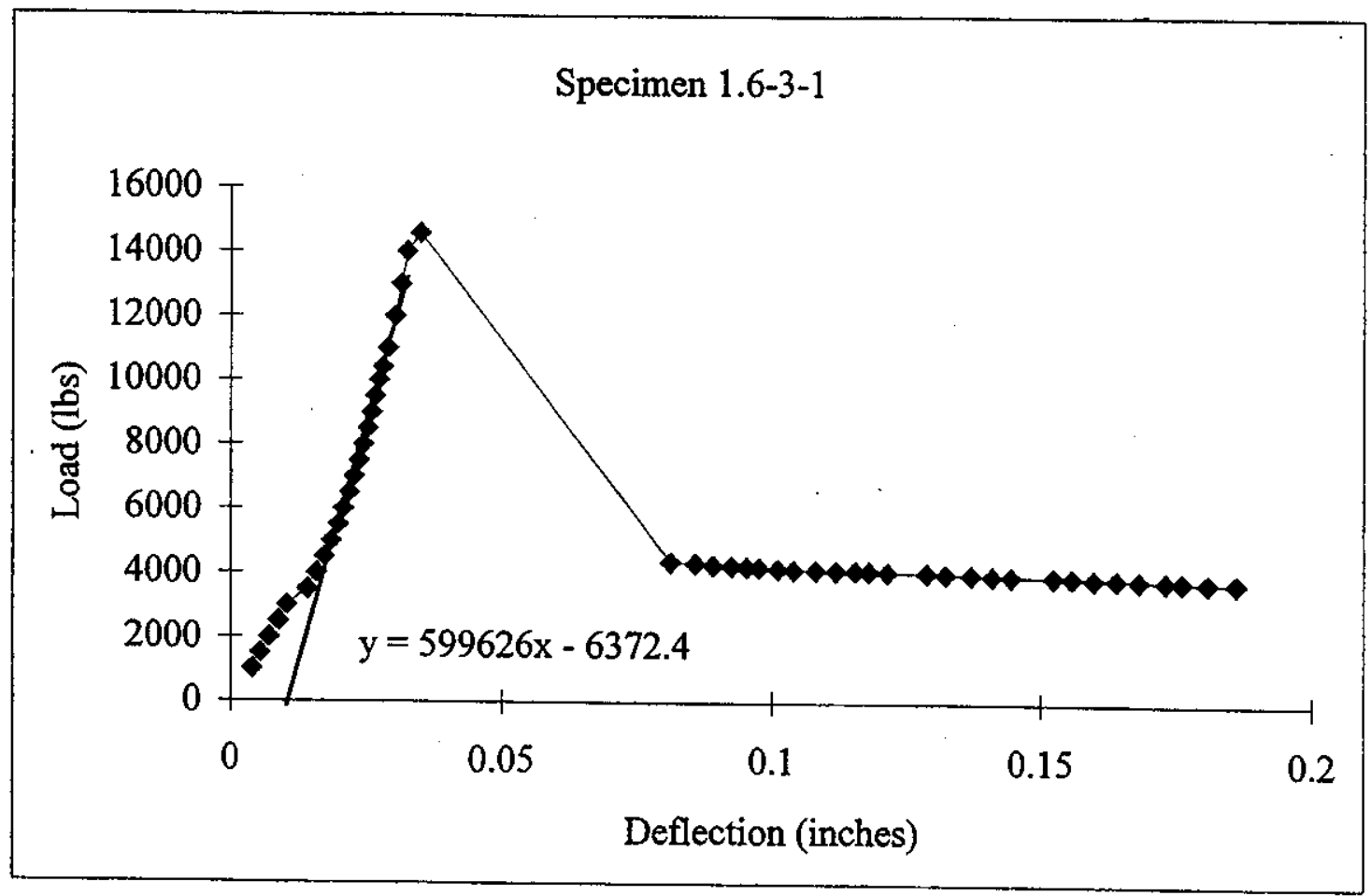

Figure E54: Load Deflection Curve for Specimen 1.6 - 3 - 1

Table E54: Load Deflection Data for Specimen 1.6 - 3 - 1

\begin{tabular}{|c|c|}
\hline $\begin{aligned} \text { First Crack Load } & =14,590 \\
\text { Midspan First Crack Deflection } & =0.0244 \\
\text { Modulus of Rupture } & =1176.61 \\
\text { First Crack Toughness } & =178.00\end{aligned}$ & $\begin{array}{l}\text { lbs } \\
\text { in } \\
\text { psi } \\
\text { lb-in }\end{array}$ \\
\hline
\end{tabular}

Specimen Type $=$ Molded

Specimen Age $=28 \quad$ days

pecimen Abnormailities $=$ None

$$
\begin{array}{rlr}
\text { Cure } & =\text { Moist Room } \\
\text { Width } & =6.2 & \text { in } \\
\text { Depth } & =6 & \text { in } \\
\text { Span Length } & =18 & \text { in } \\
O^{\prime} & =0.0106 & \text { in }
\end{array}
$$




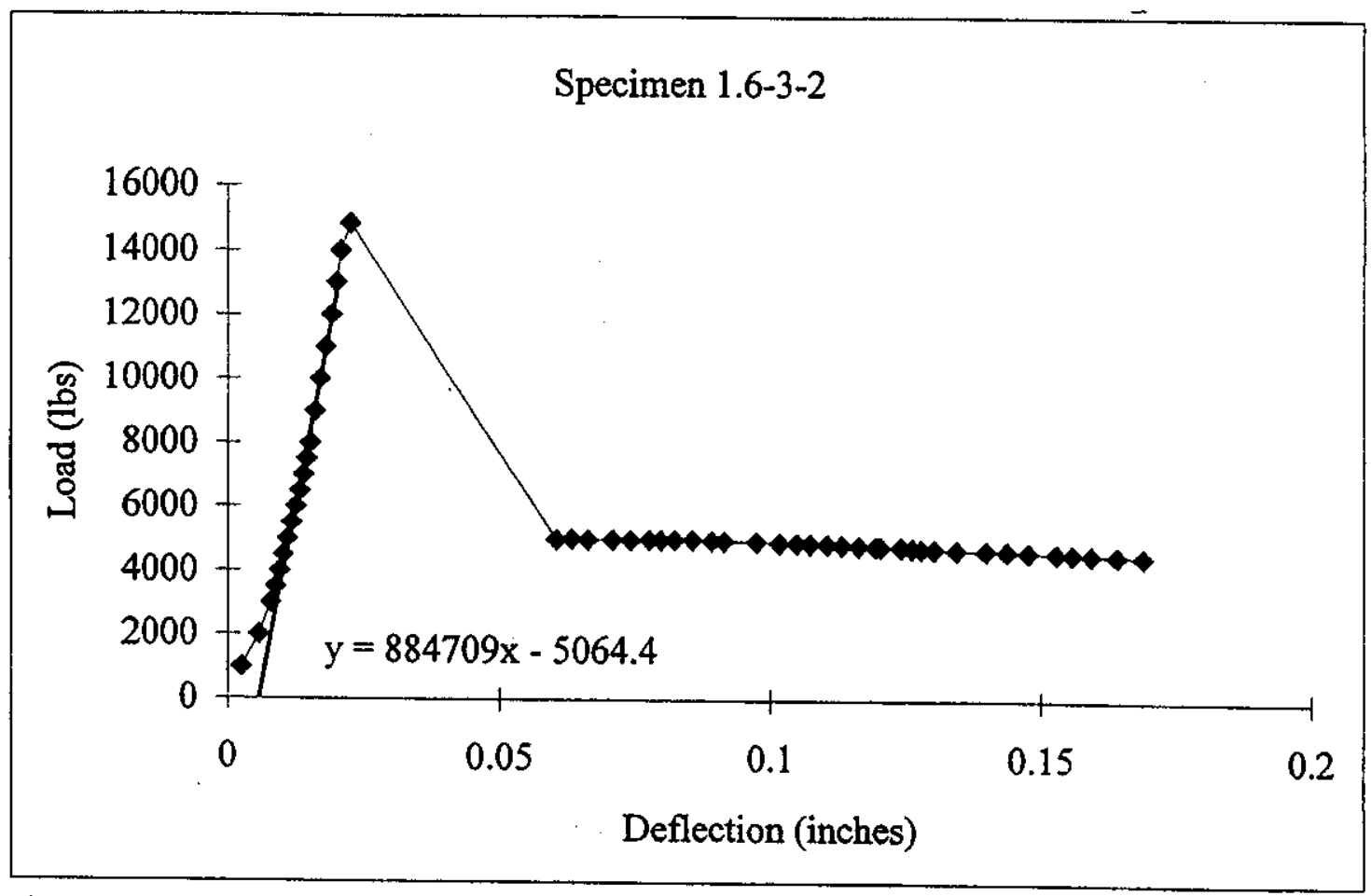

Figure E55: Load Deflection Curve for Specimen 1.6 - 3 - 2

Table E55: Load Deflection Data for Specimen 1.6 - 3 - 2

\begin{tabular}{|c|c|}
\hline $\begin{aligned} \text { First Crack Load } & =14,540 \\
\text { Midspan First Crack Deflection } & =0.0151 \\
\text { Modulus of Rupture } & =1172.58 \\
\text { First Crack Toughness } & =109.78\end{aligned}$ & $\begin{array}{l}\text { lbs } \\
\text { in } \\
\text { psi } \\
\text { lb-ir }\end{array}$ \\
\hline
\end{tabular}

Specimen Type $=$ Molded

Specimen Age $=28 \quad$ days

pecimen Abnormailities $=$ None

Cure $=$ Moist Room

Width $=6.2$ in

Depth $=6$ in

Span Length $=18$ in

$\mathrm{O}^{\prime}=0.0057$ in 


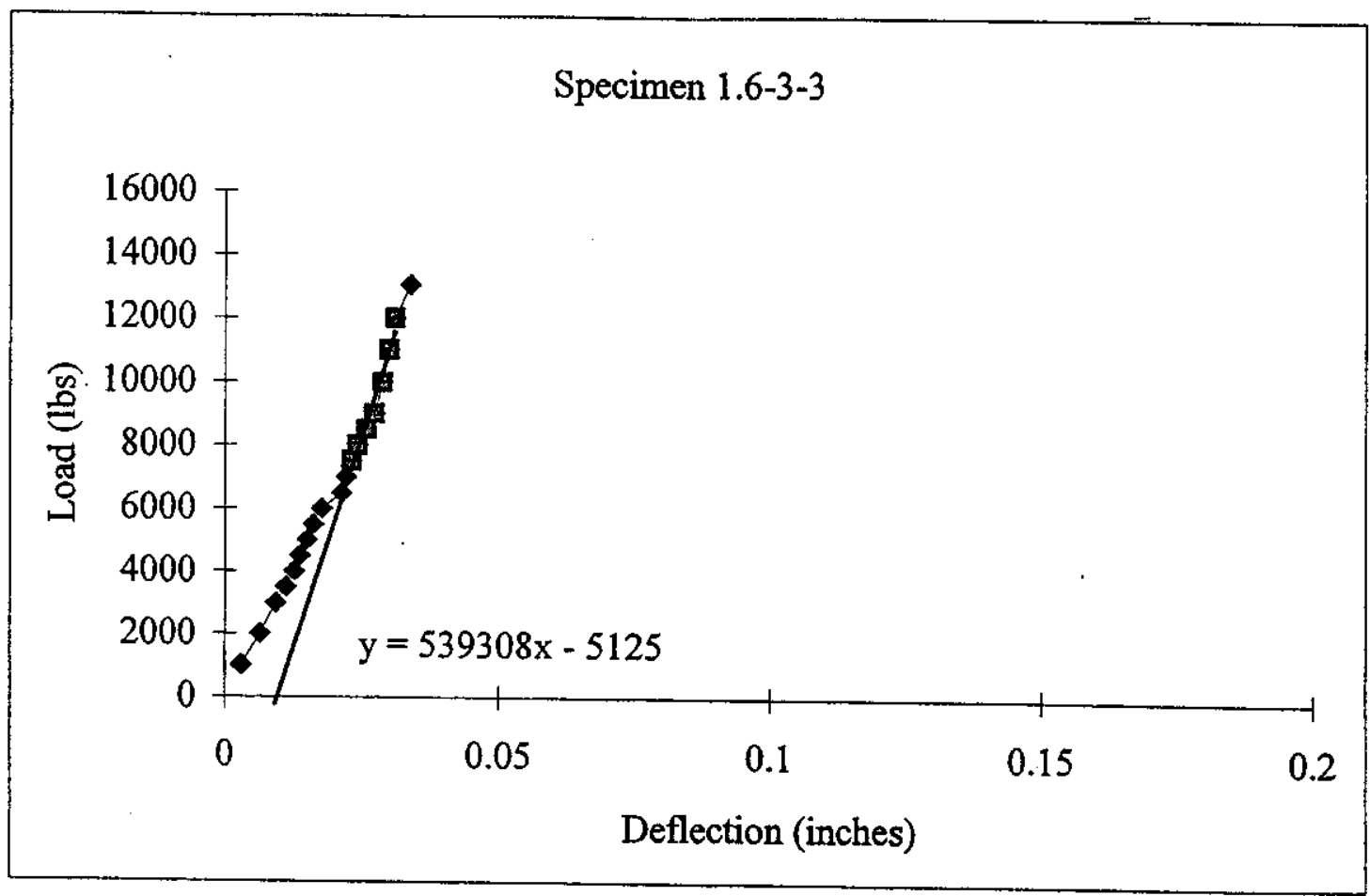

Figure E56: Load Deflection Curve for Specimen 1.6 - 3 - 3

Table E56: Load Deflection Data for Specimen 1.6 - 3 - 3

\begin{tabular}{|c|}
\hline $\begin{aligned} \text { First Crack Load } & =13,050 \\
\text { Midspan First Crack Deflection } & =0.0242 \\
\text { Modulus of Rupture } & =1052.42 \\
\text { First Crack Toughness } & =157.89\end{aligned}$ \\
\hline
\end{tabular}

Specimen Type $=$ Molded

Specimen Age $=28 \quad$ days

pecimen Abnormailities $=$ None

Cure $=$ Moist Room

Width $=6.2 \quad$ in

Depth $=6$ in

Span Length $=18 \quad$ in

$\mathrm{O}^{\prime}=0.0095 \quad$ in 


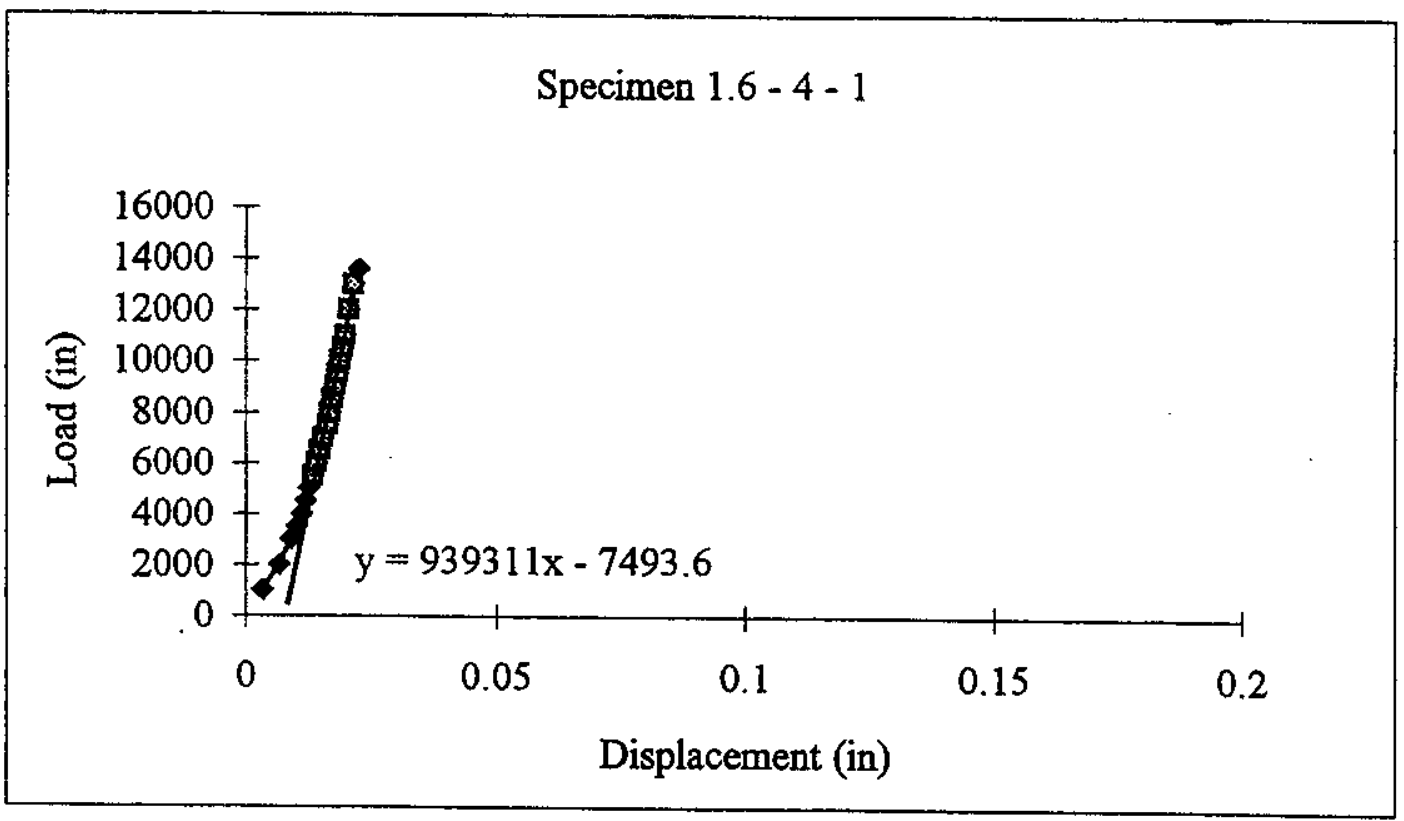

Figure E57: Load Deflection Curve for Specimen 1.6 - 4 - 1

Table E57: Load Deflection Data for Specimen 1.6 - 4 - 1

\begin{tabular}{|c|c|}
\hline $\begin{aligned} \text { First Crack Load } & =13,590 \\
\text { Midspan First Crack Deflection } & =0.0144\end{aligned}$ & $\begin{array}{l}\text { Ibs } \\
\text { in }\end{array}$ \\
\hline Modulus of Rupture $=1132.5$ & psi \\
\hline First Crack Toughness $=97.85$ & lb-in \\
\hline
\end{tabular}

$$
\text { Specimen Type }=\text { Molded }
$$

Specimen Age $=28 \quad$ days

Specimen Abnormailities $=$ None

Cure $=$ Moist Room

Width $=6$ in

Depth $=6$ in

Span Length $=18$ in

$\mathrm{O}^{\prime}=0.008$ in 


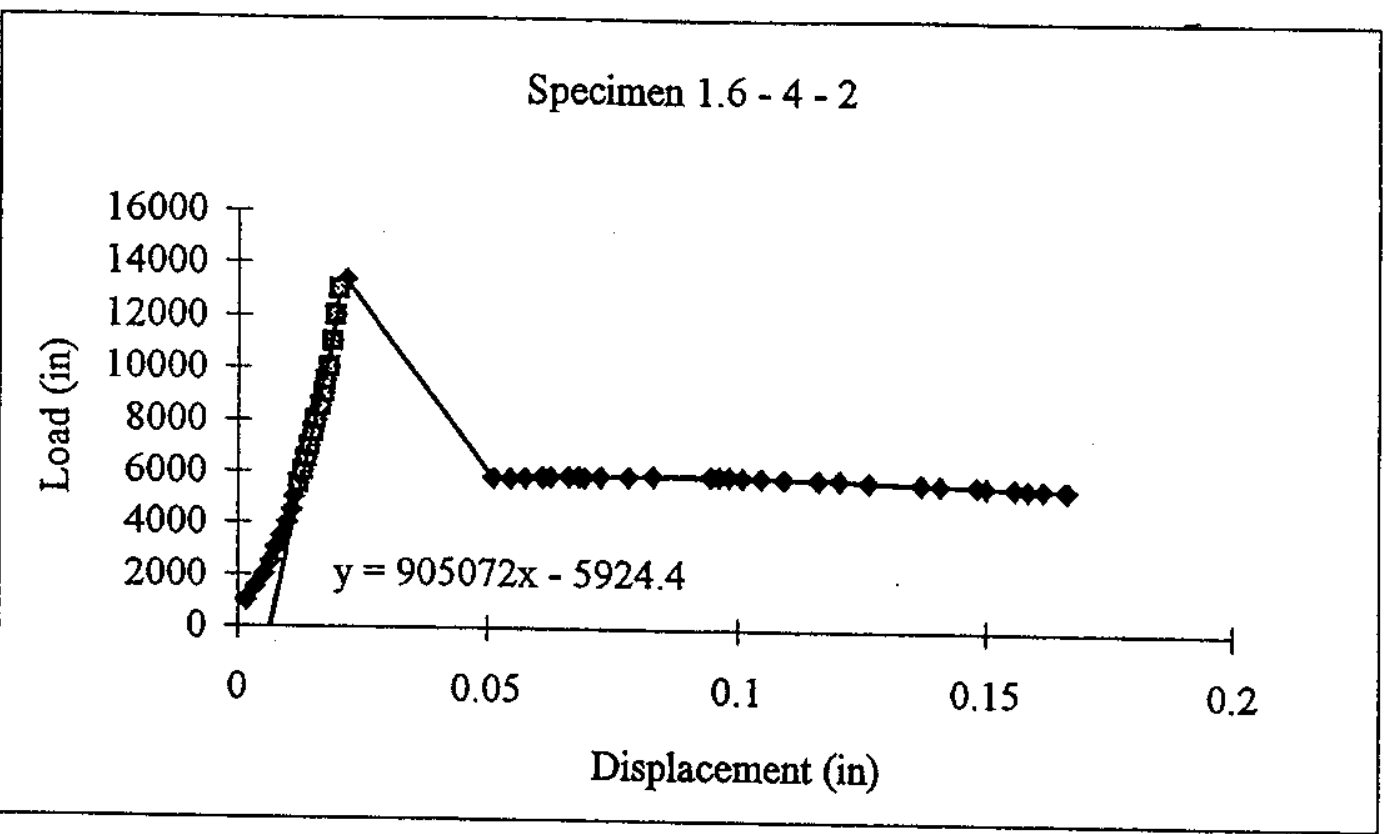

Figure E58: Load Deflection Curve for Specimen 1.6 - 4 - 2

Table E58: Load Deflection Data for Specimen 1.6 - 4 - 2

\begin{tabular}{rll|}
\hline First Crack Load & $=13,350$ & lbs \\
Midspan First Crack Deflection & $=0.0148$ & in \\
Modulus of Rupture & $=1112.5$ & $\mathrm{psi}$ \\
First Crack Toughness & $=98.79$ & lb-in
\end{tabular}

$$
\begin{array}{rlrl}
\text { Specimen Type } & =\text { Molded } & \\
\text { Specimen Age } & =28 & & \text { days } \\
\text { Specimen Abnormailities } & =\text { None } & \\
\text { Cure } & =\text { Moist Room } \\
\text { Width } & =6 & \text { in } \\
\text { Depth } & =6 & \text { in } \\
\text { Span Length } & =18 & \text { in } \\
O^{\prime} & =0.0065 & \text { in }
\end{array}
$$




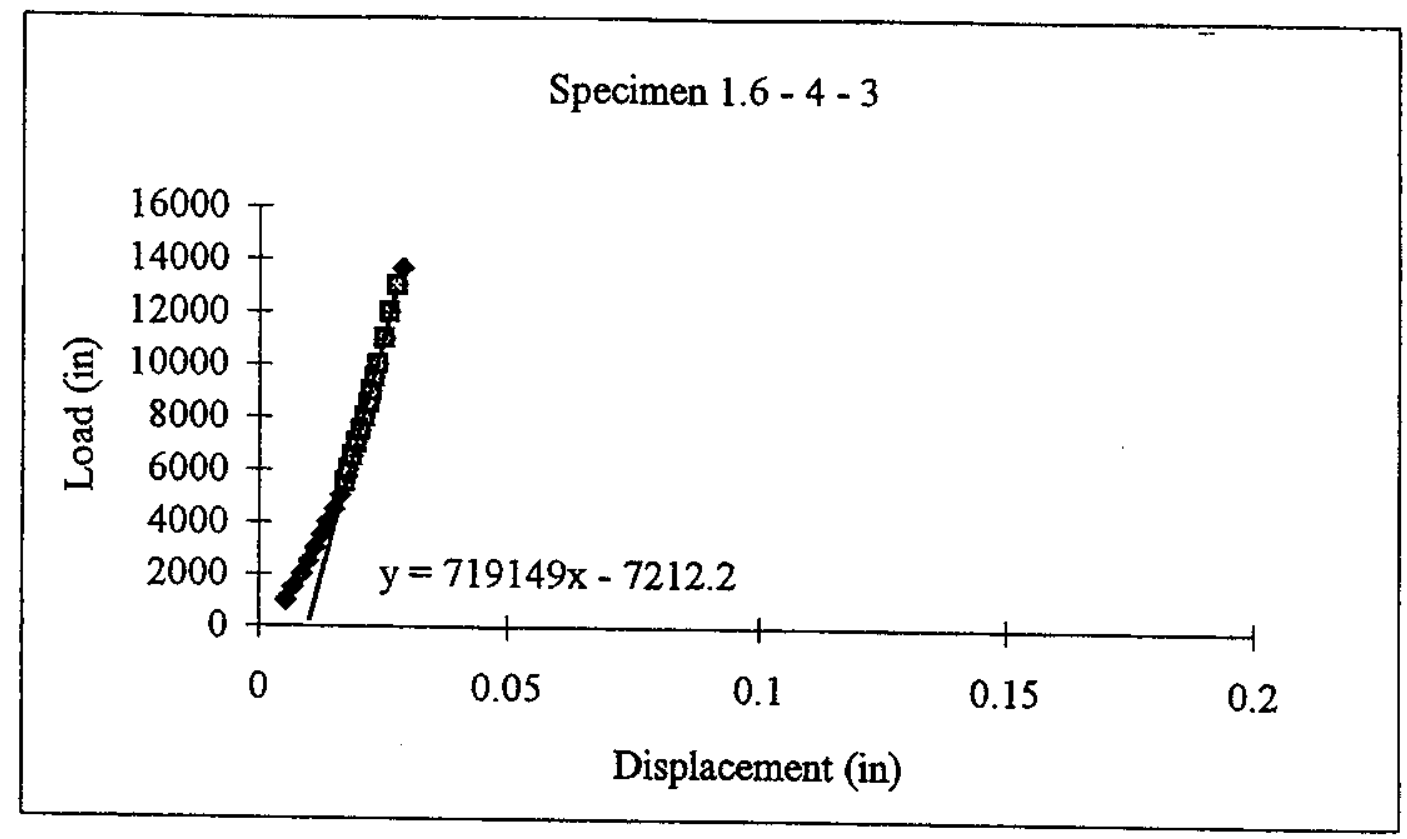

Figure E59: Load Deflection Curve for Specimen 1.6 - 4 - 3

Table E59: Load Deflection Data for Specimen 1.6 - 4 - 3

\begin{tabular}{|c|c|}
\hline $\begin{aligned} \text { First Crack Load } & =13,630 \\
\text { Midspan First Crack Deflection } & = \\
\text { Modulus of Rupture } & =1135.83 \\
\text { First Crack Toughness } & =0.0190\end{aligned}$ & $\begin{array}{l}\text { ibs } \\
\text { in } \\
\text { psi } \\
\text { lb-in }\end{array}$ \\
\hline
\end{tabular}

$\begin{array}{rlrl}\text { Specimen Type } & =\text { Molded } \\ \text { Specimen Age } & =28 & & \text { days } \\ \text { Specimen Abnormailities } & =\text { None } & \\ \text { Cure } & =\text { Moist Room } \\ \text { Width } & =6 & \text { in } \\ \text { Depth } & =6 & \text { in } \\ \text { Span Length } & =18 & \text { in } \\ O^{\prime} & =0.01 & \text { in }\end{array}$


Specimen 1.6-5-1

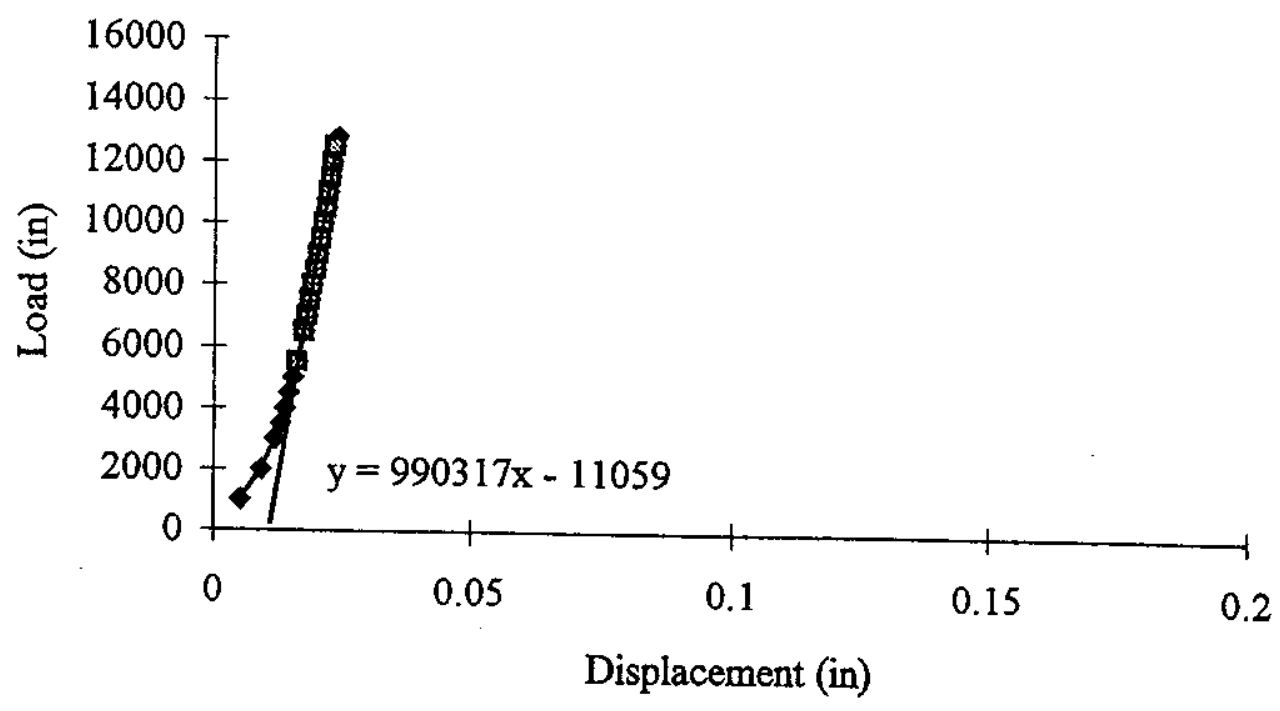

Figure E60: Load Deflection Curve for Specimen 1.6 - 5 - 1

Table E60: Load Deflection Data for Specimen 1.6 - 5 - 1

\begin{tabular}{|c|c|}
\hline $\begin{array}{r}\text { First Crack } \\
\text { Midspan First Crack Defle } \\
\text { Modulus of Ru } \\
\text { First Crack Toug }\end{array}$ & $\begin{array}{l}\text { lbs } \\
\text { in } \\
\text { psi } \\
\text { lb-in }\end{array}$ \\
\hline
\end{tabular}

Specimen Type $=$ Molded

Specimen Age $=28 \quad$ days

Specimen Abnormailities $=$ None

Cure $=$ Moist Room

Width $=6 \quad$ in

Depth $=6$ in

Span Length $=18 \quad$ in

$$
\mathrm{O}^{\prime}=0.0112 \text { in }
$$




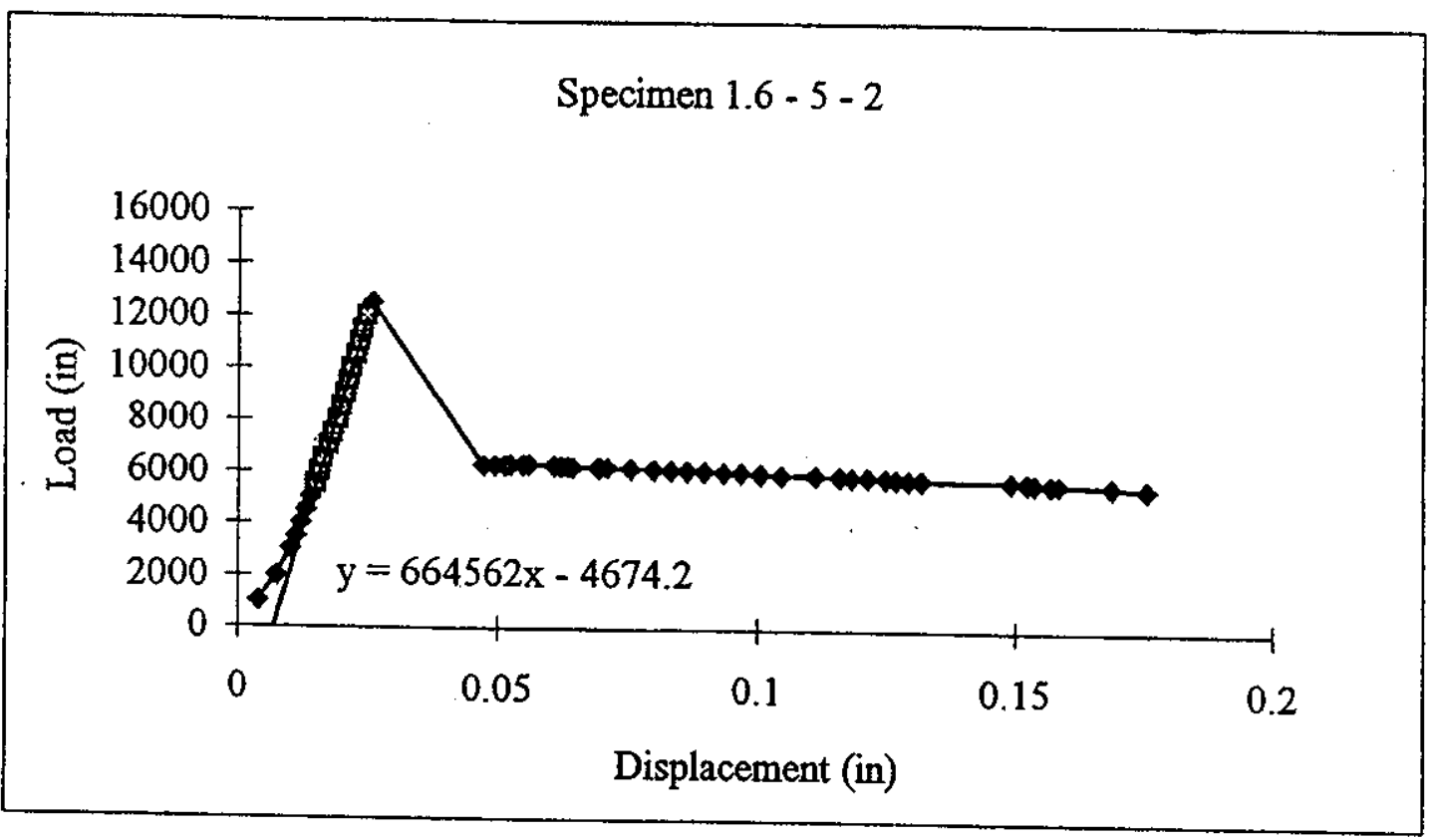

Figure E61: Load Deflection Curve for Specimen 1.6 - 5 - 2

Table E61: Load Deflection Data for Specimen 1.6 - 5 - 2

\begin{tabular}{|c|c|}
\hline $\begin{aligned} \text { First Crack Load } & =12,500 \\
\text { Midspan First Crack Deflection } & =0.0188 \\
\text { Modulus of Rupture } & =1041.67 \\
\text { First Crack Toughness } & =117.50\end{aligned}$ & $\begin{array}{l}\text { lbs } \\
\text { in } \\
\text { psi } \\
\text { lb-in }\end{array}$ \\
\hline
\end{tabular}

Specimen Type $=$ Molded

Specimen Age $=28$ days

Specimen Abnormailities $=$ None

Cure $=$ Moist Room

Width $=6$ in

Depth $=6$ in

Span Length $=18$ in

$\mathrm{O}^{\prime}=0.007 \quad$ in 


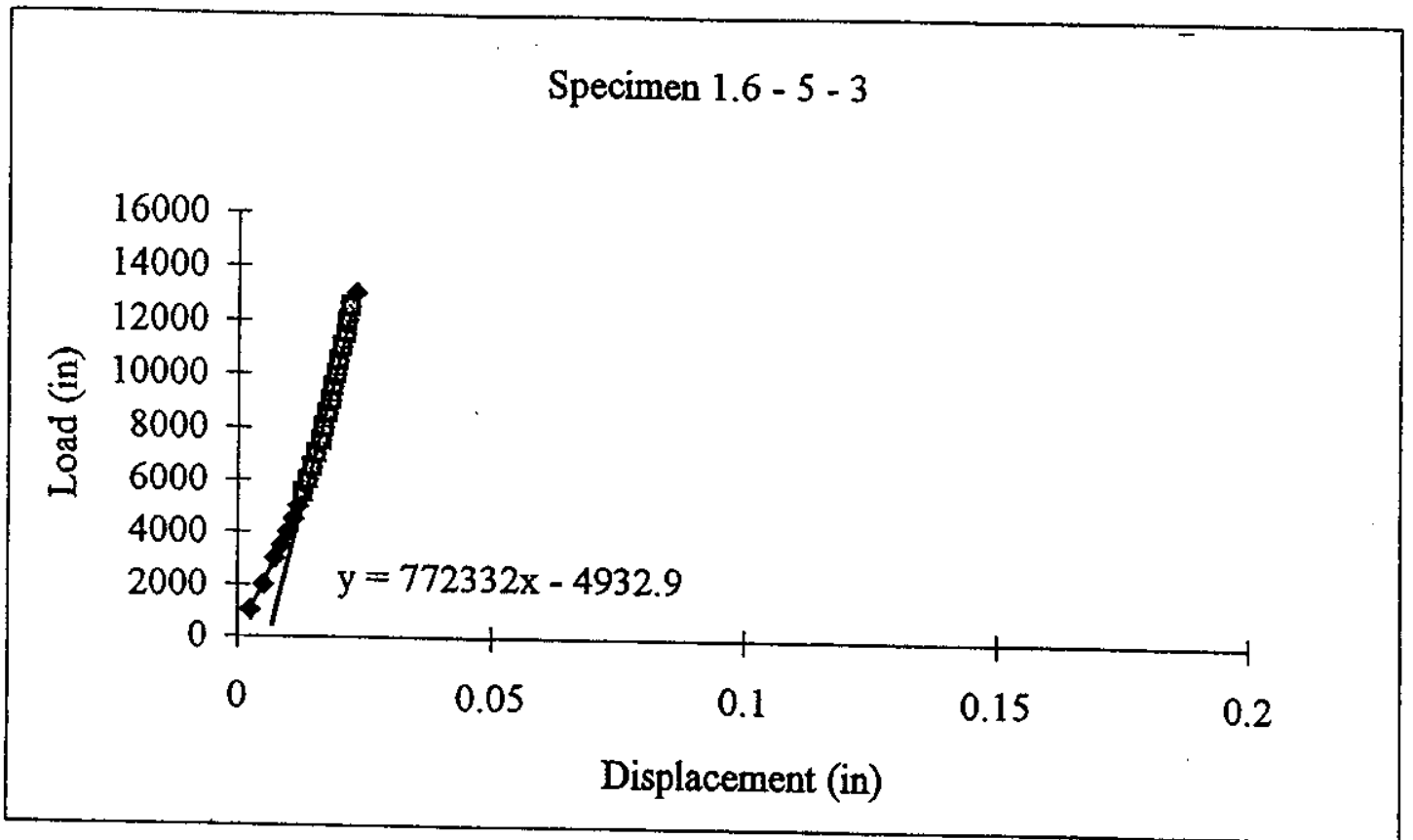

Figure E62: Load Deflection Curve for Specimen 1.6 - 5 - 3

Table E62: Load Deflection Data for Specimen 1.6 - 5 - 3

\begin{tabular}{|c|c|}
\hline First Crack Load $=13,000$ & lbs \\
\hline Midspan First Crack Deflection $=0.0168$ & in \\
\hline Modulus of Rupture $=1083.33$ & psi \\
\hline First Crack Toughness $=109.20$ & ib-in \\
\hline
\end{tabular}

Specimen Type $=$ Molded

Specimen Age $=29 \quad$ days

Specimen Abnormailities $=$ None

Cure $=$ Moist Room

Width $=6 \quad$ in

Depth $=6$ in

Span Length $=18$ in

$\mathrm{O}^{\prime}=0.0064$ in 


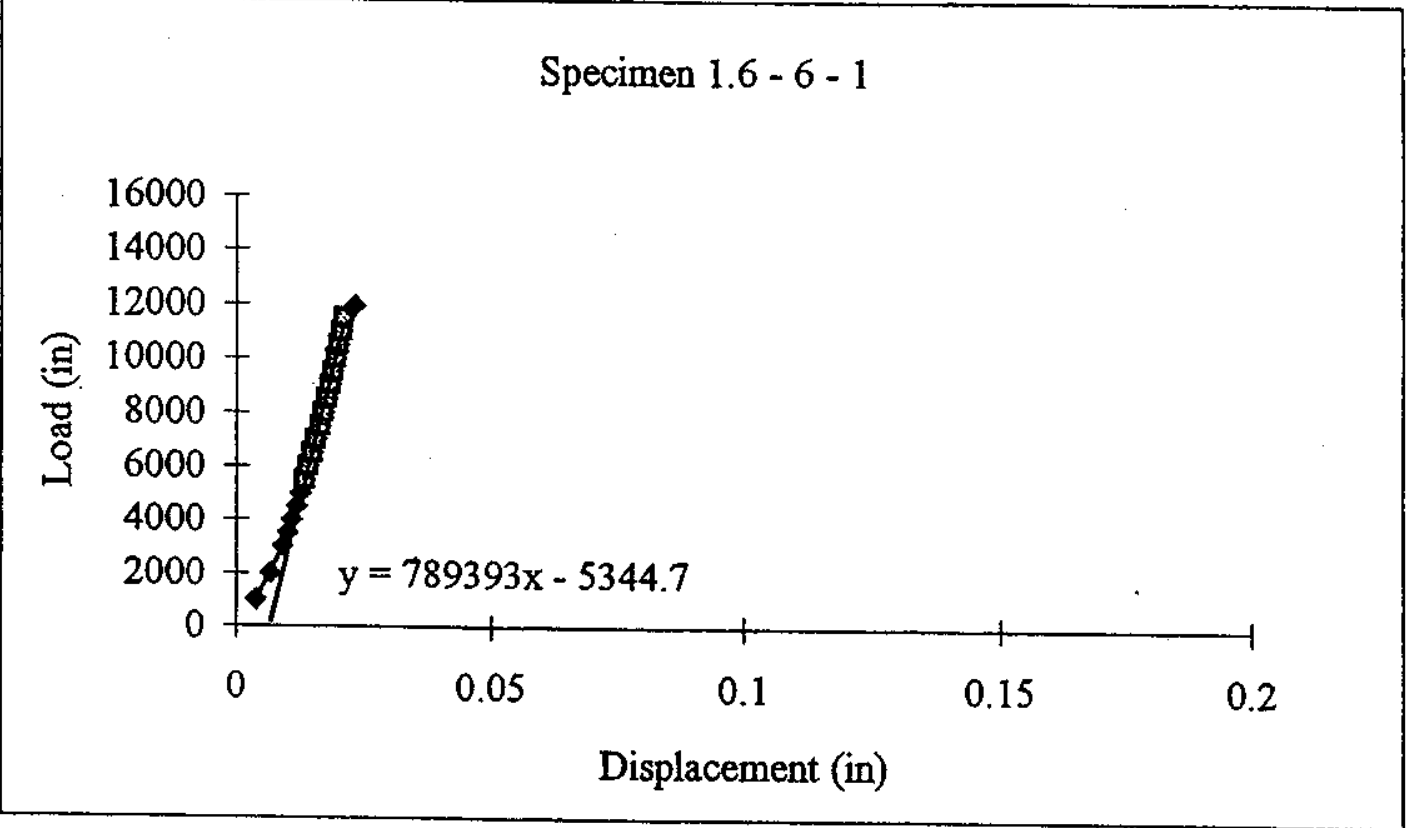

Figure E63: Load Deflection Curve for Specimen 1.6 - 6 - 1

Table E63: Load Deflection Data for Specimen 1.6 - 6 - 1

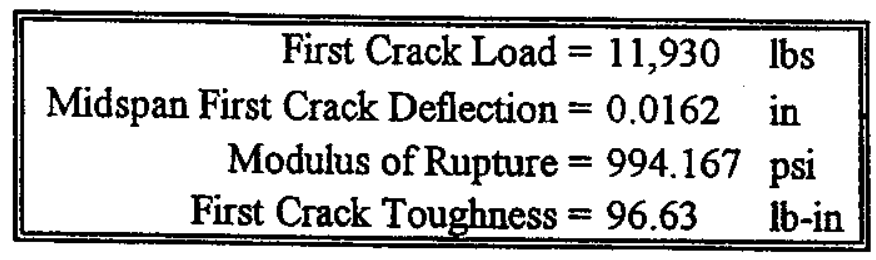

Specimen Type $=$ Molded

Specimen Age $=28$ days

Specimen Abnormailities $=$ None

Cure $=$ Moist Room

Width $=6$ in

Depth $=6$ in

Span Length $=18$ in

$\mathrm{O}^{\prime}=0.0068$ in 


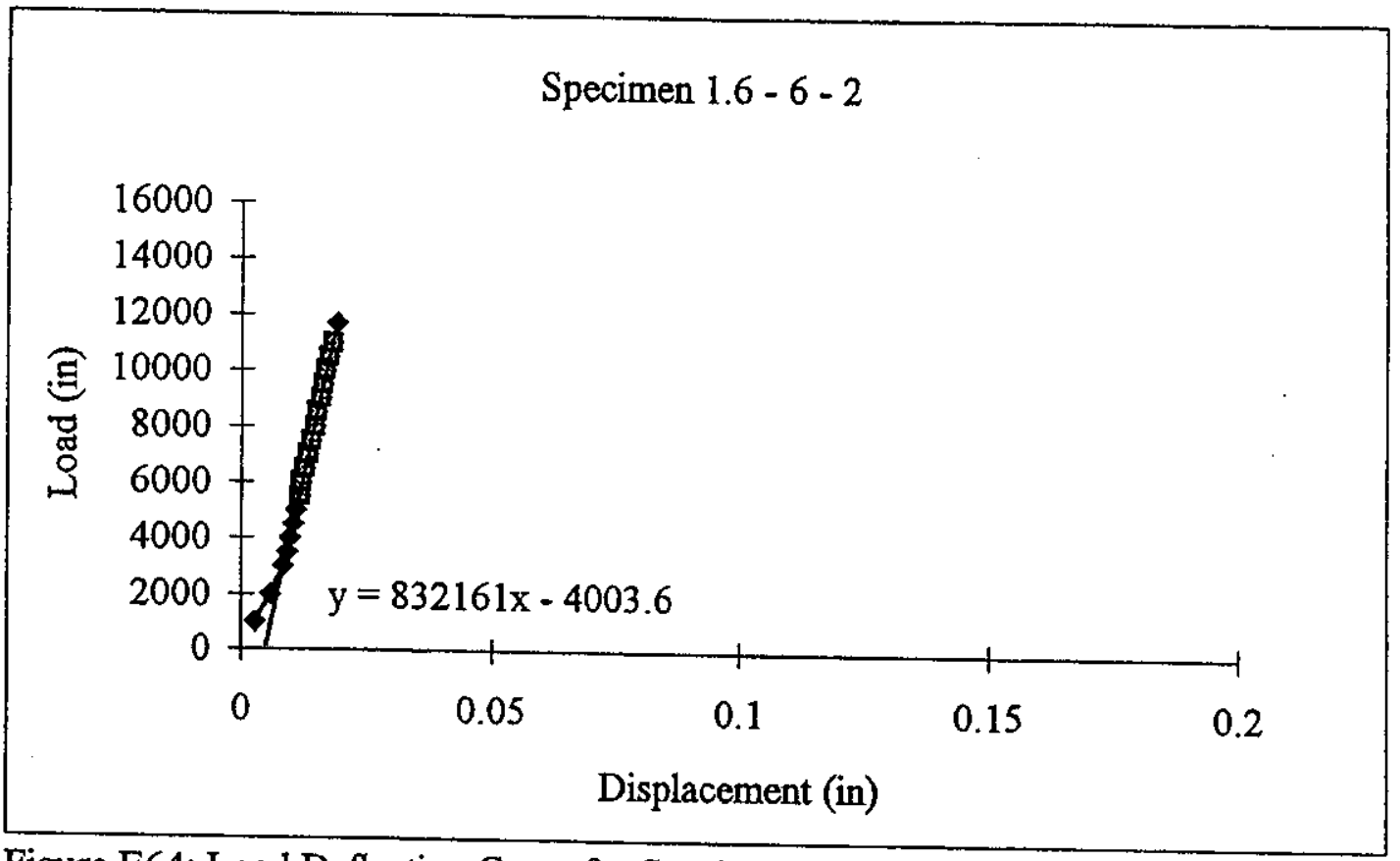

Figure E64: Load Deflection Curve for Specimen 1.6 - 6 - 2

Table E64: Load Deflection Data for Specimen 1.6 - 6 - 2

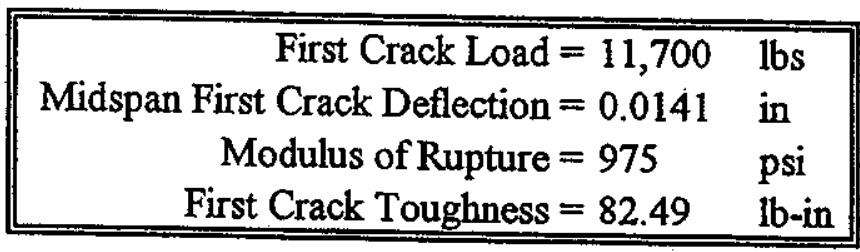

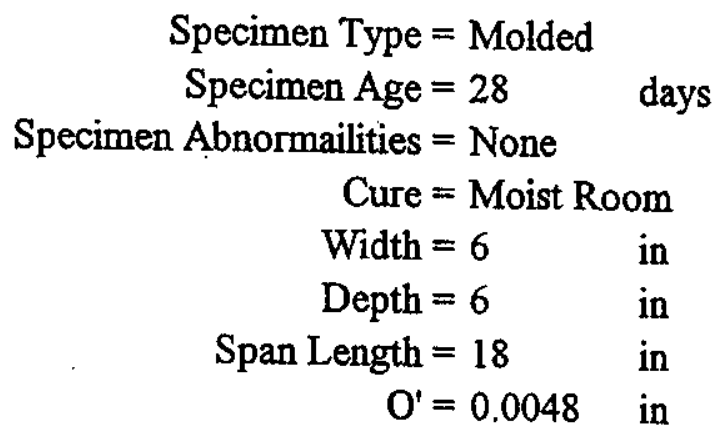




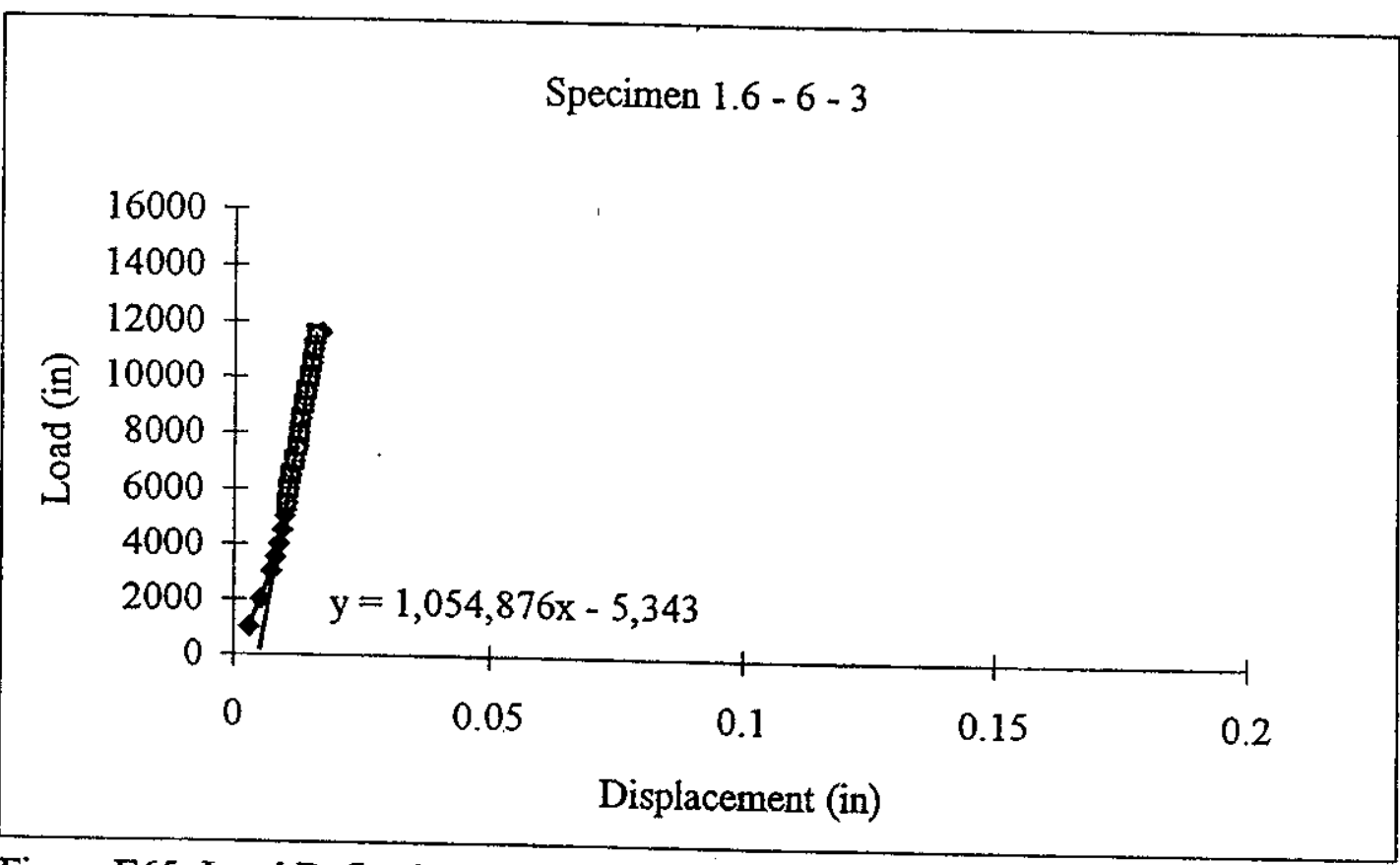

Figure E65: Load Deflection Curve for Specimen 1.6 - 6-3

Table E65: Load Deflection Data for Specimen 1.6 - 6-3

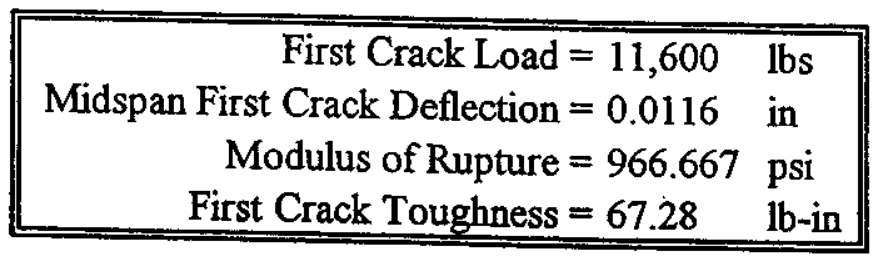

Specimen Type $=$ Molded

$$
\text { Specimen Age }=28 \quad \text { days }
$$

Specimen Abnormailities $=$ None

$$
\begin{array}{rlrl}
\text { Cure } & =\text { Moist Room } \\
\text { Width } & =6 & \text { in } \\
\text { Depth } & =6 & \text { in } \\
\text { Span Length } & =18 & \text { in } \\
O^{\prime} & =0.0053 & \text { in }
\end{array}
$$




\section{Specimen $1.6-7-1$}

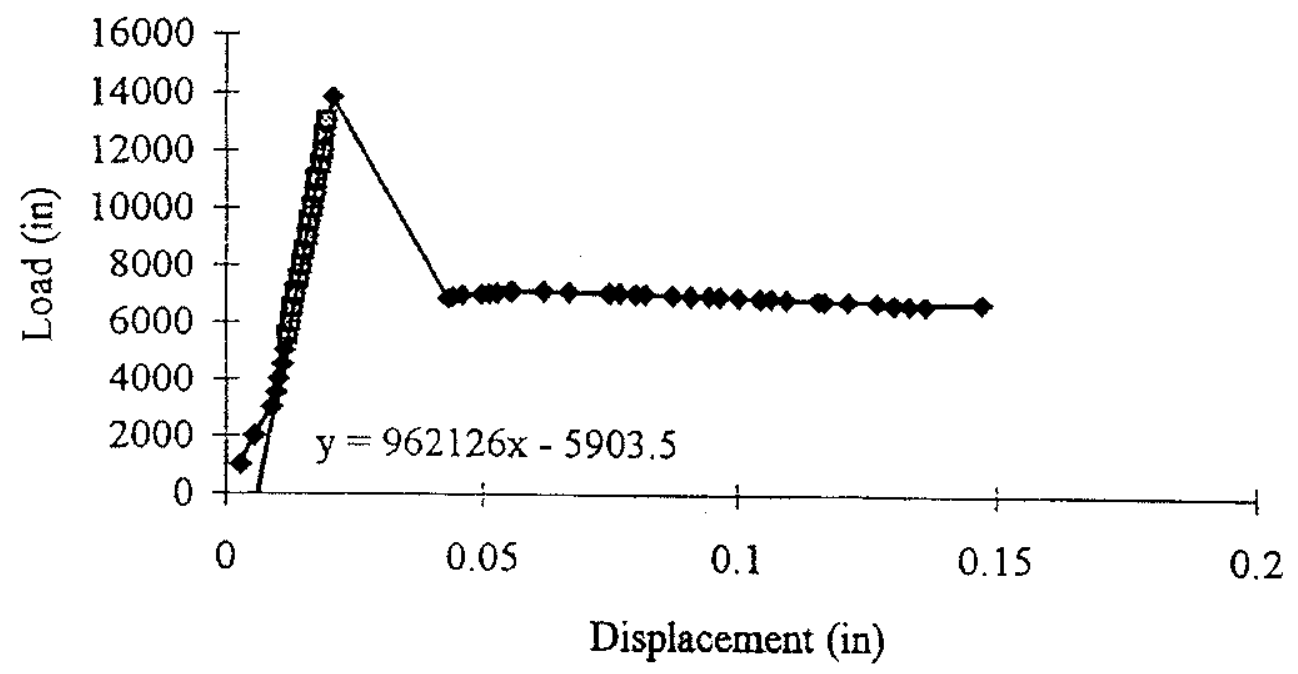

Figure E66: Load Deflection Curve for Specimen 1.6-7-1

Table E66: Load Deflection Data for Specimen 1.6-7-1

\begin{tabular}{rlll|}
\hline First Crack Load & $=13,810$ & lbs \\
Midspan First Crack Deflection & $=0.0144$ & in \\
Modulus of Rupture & $=1113.71$ & psi \\
First Crack Toughness & $=99.43$ & lb-in
\end{tabular}

$$
\begin{array}{rlr}
\text { Specimen Type } & =\text { Molded } & \\
\text { Specimen Age } & =28 & \text { days } \\
\text { Specimen Abnormalities } & =\text { None } & \\
\text { Cure } & =\text { Moist Room } \\
\text { Width } & =6.2 \quad \text { in } \\
\text { Depth } & =6 & \text { in } \\
\text { Span Length } & =18 & \text { in } \\
0^{\prime} & =0.0061 \quad \text { in }
\end{array}
$$




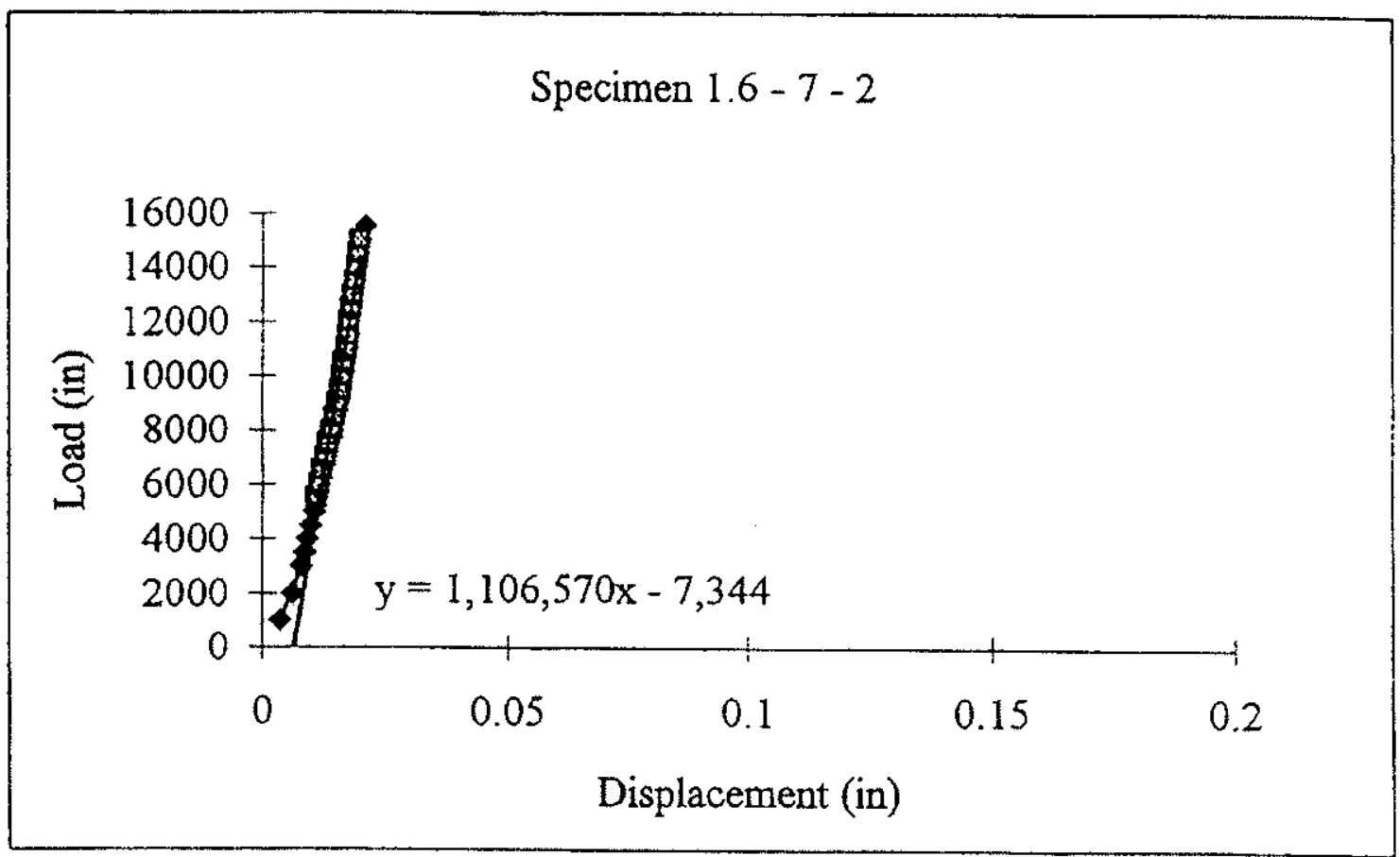

Figure E67: Load Deflection Curve for Specimen 1.6- 7 - 2

Table E67: Load Deflection Data for Specimen 1.6-7-2

\begin{tabular}{rlll|}
\hline First Crack Load & $=15,510$ & lbs \\
Midspan First Crack Deflection & $=0.0141$ & in \\
Modulus of Rupture & $=1230.95$ & psi \\
First Crack Toughness & $=109.35$ & $\mathrm{lb}$-in \\
\hline
\end{tabular}

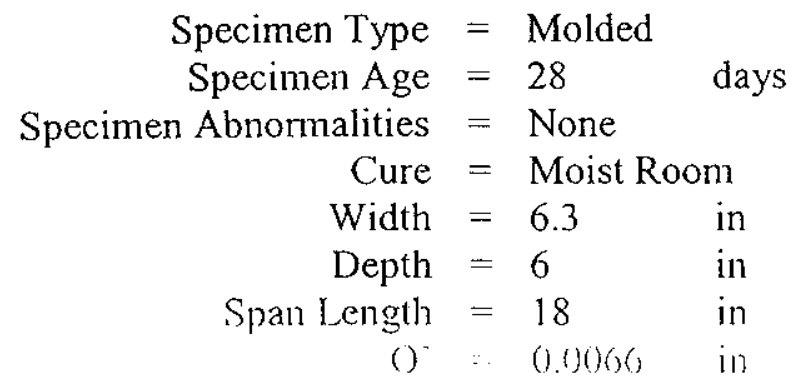




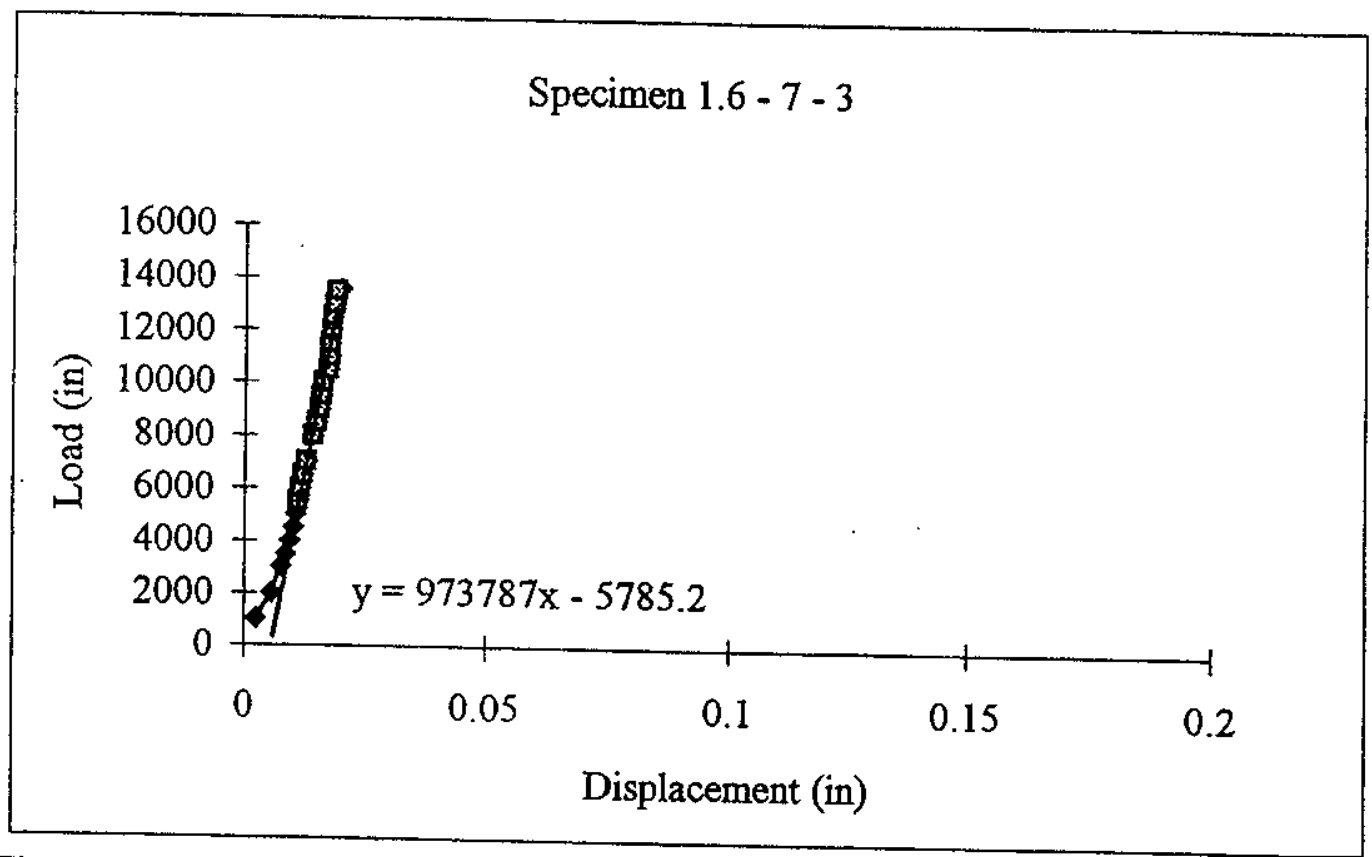

Figure E68: Load Deflection Curve for Specimen 1.6 - 7 - 3

Table E68: Load Deflection Data for Specimen 1.6 - 7 - 3

\begin{tabular}{|c|c|}
\hline $\begin{aligned} \text { First Crack Load } & =13,570 \\
\text { Midspan First Crack Deflection } & =0.014 \\
\text { Modulus of Rupture } & =1094.35 \\
\text { First Crack Toughness } & =94.99\end{aligned}$ & $\begin{array}{l}\text { lbs } \\
\text { in } \\
\mathrm{psi} \\
\mathrm{lb}-\mathrm{in}\end{array}$ \\
\hline
\end{tabular}

Specimen Type $=$ Molded

Specimen Age $=28 \quad$ days

Specimen Abnormailities $=$ None

Cure $=$ Moist Room

Width $=6.2$ in

Depth $=6$ in

Span Length $=18 \quad$ in

$\mathrm{O}^{\prime}=0.0059$ in 


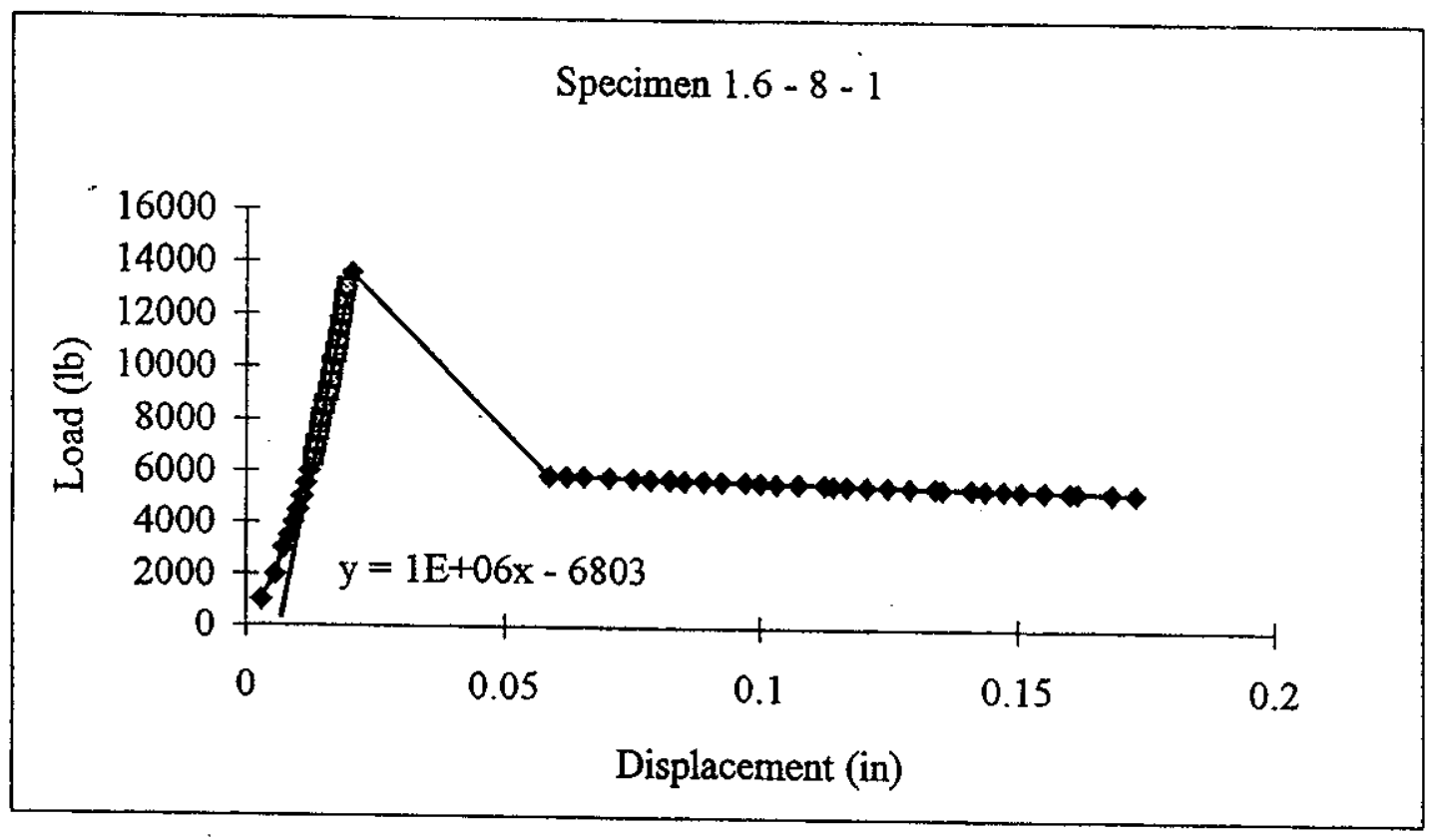

Figure E69: Load Deflection Curve for Specimen 1.6 - 8 - 1

Table E69: Load Deflection Data for Specimen 1.6 - 8 - 1

\begin{tabular}{|c|c|}
\hline First Crack Load $=13,560$ & lbs \\
\hline Midspan First Crack Deflection $=0.0136$ & in \\
\hline Modulus of Rupture $=1130$ & psi \\
\hline First Crack Toughness $=92.21$ & lb-in \\
\hline
\end{tabular}

Specimen Type $=$ Molded

Specimen Age $=28 \quad$ days

Specimen Abnormailities $=$ None

Cure $=$ Moist Room

Width $=6 \quad$ in

Depth $=6$ in

Span Length $=18$ in

$\mathrm{O}^{\prime}=0.0068$ in 


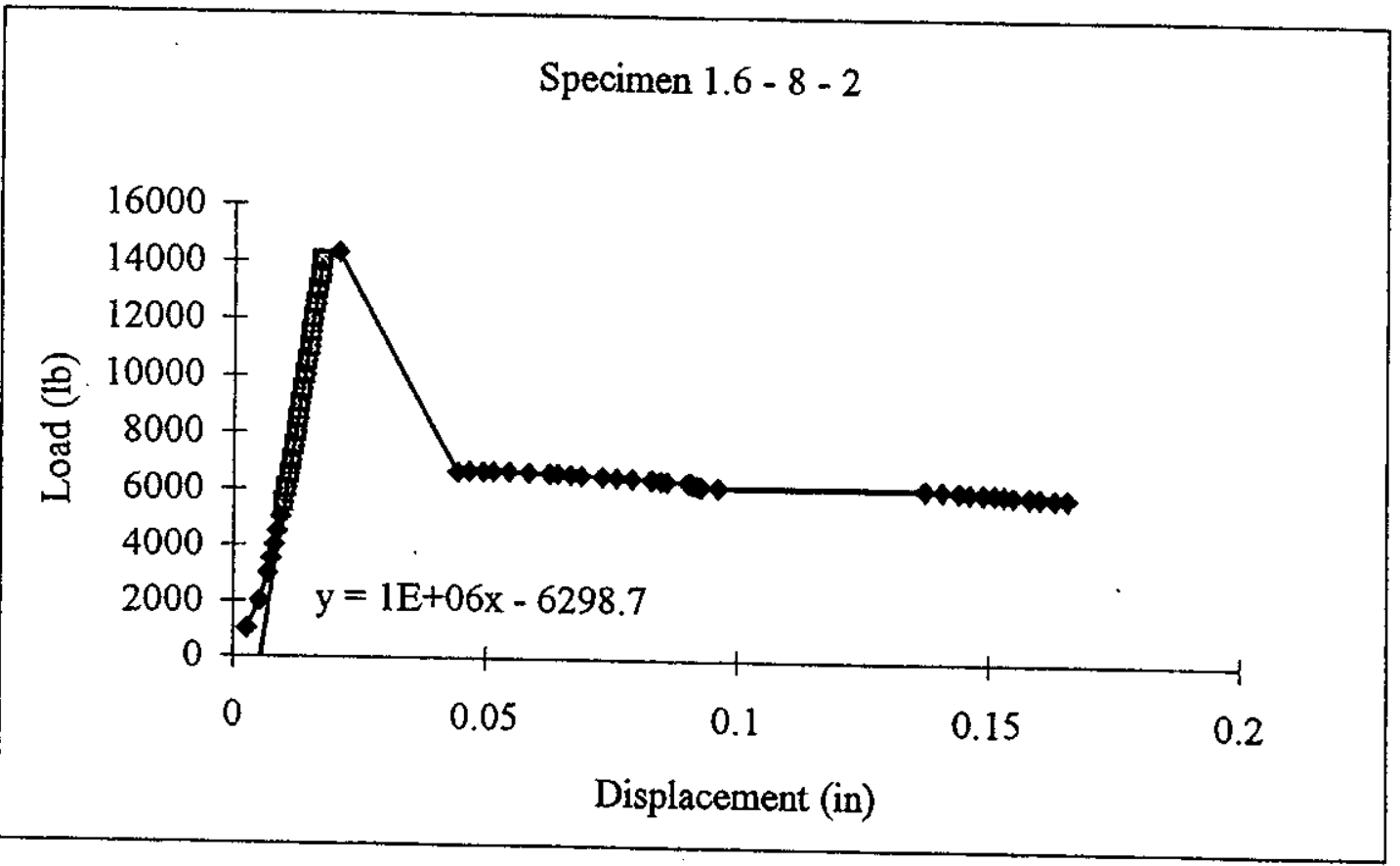

Figure E70: Load Deflection Curve for Specimen 1.6 - 8 - 2

Table E70: Load Deflection Data for Specimen 1.6 - 8 - 2

\begin{tabular}{|c|c|}
\hline $\begin{aligned} \text { First Crack Load } & =14,290 \\
\text { Midspan First Crack Deflection } & =0.0143 \\
\text { Modulus of Rupture } & =1190.83 \\
\text { First Crack Toughness } & =102.17\end{aligned}$ & $\begin{array}{l}\text { Ibs } \\
\text { in } \\
\text { psi } \\
\text { lb-in }\end{array}$ \\
\hline
\end{tabular}

Specimen Type $=$ Molded

Specimen Age $=28 \quad$ days

Specimen Abnormailities $=$ None

Cure $=$ Moist Room

Width $=6 \quad$ in

Depth $=6$ in

Span Length $=18 \quad$ in

$\mathrm{O}^{\prime}=0.0063$ in 


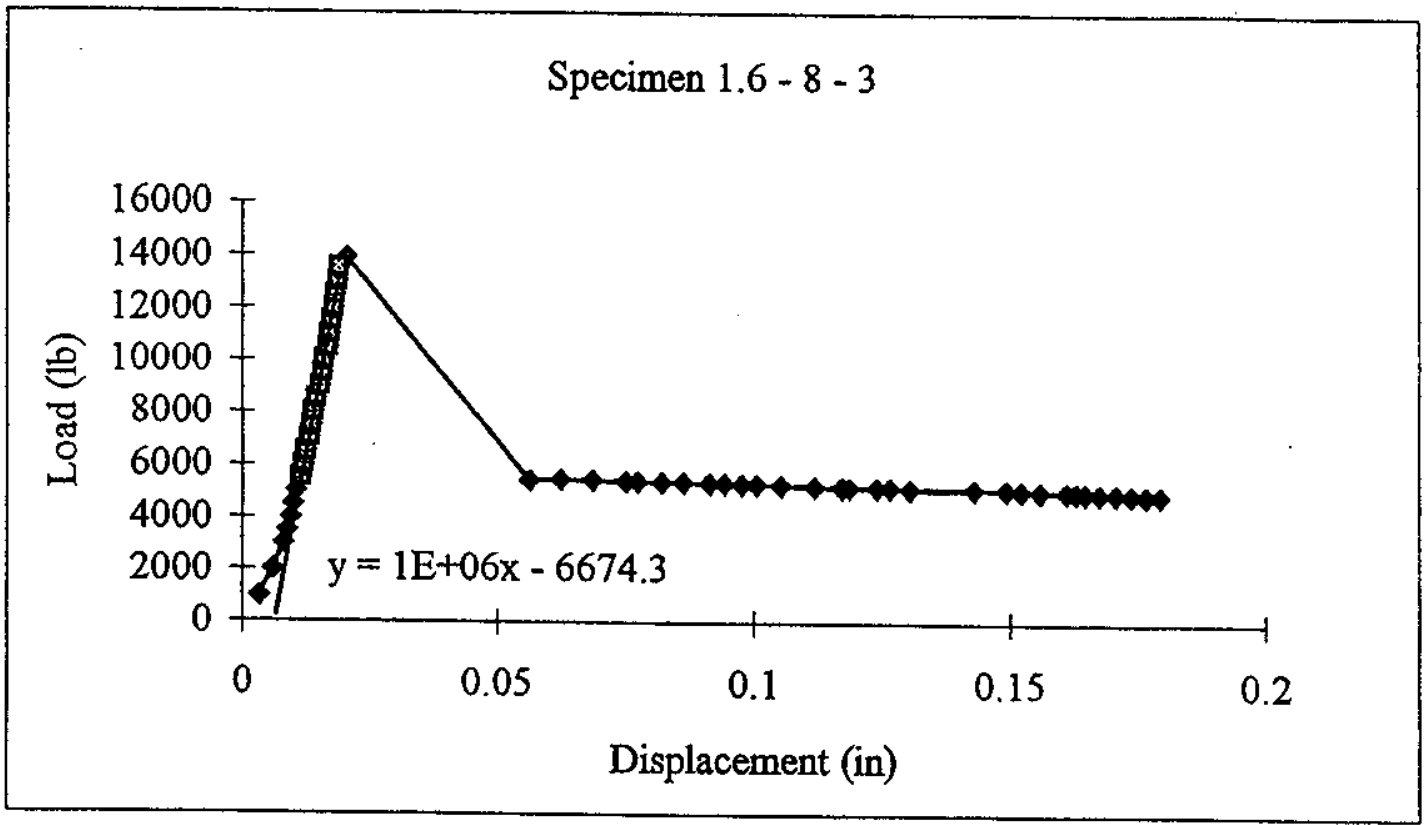

Figure E71: Load Deflection Curve for Specimen $1.6-8-3$

Table E71: Load Deflection Data for Specimen $1.6-8-3$

\begin{tabular}{|rl|}
\hline First Crack Load $=13,890$ & lbs \\
Midspan First Crack Deflection $=0.0139$ & in \\
Modulus of Rupture $=1157.5$ & psi \\
First Crack Toughness $=96.54$ & lb-in \\
\hline
\end{tabular}

Specimen Type $=$ Molded

Specimen Age $=28$ days

Specimen Abnormailities $=$ None

Cure $=$ Moist Room

Width $=6 \quad$ in

Depth $=6$ in

Span Length $=18$ in

$\mathrm{O}^{\prime}=0.0067 \quad$ in 